\title{
ARTICLES
}

\section{REGULATION BY DEAL: THE GOVERNMENT'S RESPONSE TO THE FINANCIAL CRISIS}

\author{
STEVEN M. DAVIDOFF* \\ DAVID ZARING**
}

\section{TABLE OF CONTENTS}

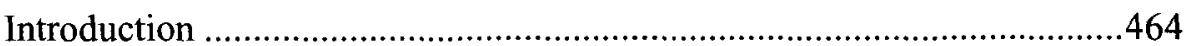

I. The Government in Crisis ..........................................................471

A. Before the Crisis: The Macroeconomic Government ...............471

B. The Preliminary Stage: The Government as Deal

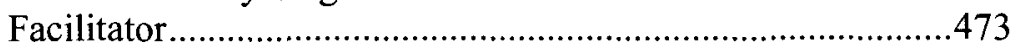

1. The Lessons of Bear Stearns............................................473

2. The Fall of Bear Stearns ...............................................476

3. JPMorgan Acquires Bear Stearns ......................................480

C. The Initial Stage: The Government as Dealmaker ..................484

1. The Nationalization of Fannie Mae and Freddie Mac ........486

2. The Week that Changed Everything..................................491

a. The Bankruptcy of Lehman Brothers and the Sale of Merrill Lynch

* Associate Professor, University of Connecticut School of Law; B.A., University of Pennsylvania; J.D., Columbia University School of Law; M.S., Finance, London Business School.

** Assistant Professor, University of Pennsylvania-The Wharton School of Business; B.A., Swarthmore College; J.D., Harvard Law School.

Thanks to Matt Bodie, Isaac Corre, Victor Fleischer, Anna Gelpern, Jeff Gordon, Claire Hill, Eric Orts, Jim Park, Larry Ribstein, Andrew Metrick, Eric Posner, David Skeel, Usha Rodriguez, Roberta Romano, and Paul Rose for comments, as well as the participants in workshops and roundtables at Illinois, Penn, and Texas. Small portions of the Article appeared in the testimony of Steven M. Davidoff before the Senate Committee on Homeland Security and Governmental Affairs on January 21, 2008. Thanks also to Brianne Blakey and Nikki Cho for research assistance. 
b. The Nationalization of AIG.........................................494

c. The SEC Takes Action ................................................500

d. The Treasury Guarantees the Money Market

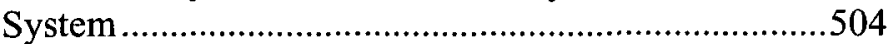

D. The End of the Beginning: Government as Deal Machine ......508

1. The Bankruptcy of Washington Mutual ...........................508

2. The Forced Sale of Wachovia...........................................509

3. The Saving of Morgan Stanley ........................................511

II. The Government Takes Comprehensive Action ............................512

A. The Paulson Proposal and the Congressional Reaction............513

B. The Bailout Statute ...........................................................5518

C. The Commercial Paper Program ...........................................5524

III. The Aftermath of Government Action........................................525

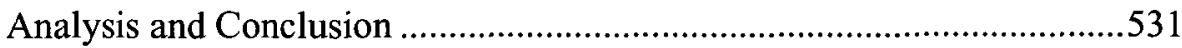

\section{INTRODUCTION}

"Who are these guys that just keep coming?"

-Treasury Secretary Henry M. Paulson Jr., speaking of the serial collapse of

U.S. financial institutions.

Many people now claim that they knew that a financial crisis was coming, but it does not appear that those working for the government were among them. Perhaps they should have been-the government was certainly very close to the problem. Federal Reserve macroeconomic policy, inadequate regulation of the two government-sponsored enterprises (GSEs) the Federal National Mortgage Association (Fannie Mae) and the Federal Home Loan Mortgage Corporation (Freddie Mac) and other regulatory failures with respect to the mortgage-origination industry, financial institution oversight, ratings agencies, and the securitization market all played their part in creating an unprecedented real estate and credit bubble. $^{2}$

But as part of the solution, the government's contribution was much more fitful. When the real estate bubble popped, with catastrophic implications for the financial institutions that facilitated property purchases, the credit market, and, eventually, all of the participants in the worldwide financial system, the federal government reacted slowly, and then

1. Joe Nocera \& Edmund L. Andrews, Running a Step Behind as a Crisis Raged, N.Y. TIMES, Oct. 23,2008 , at A1.

2. The causes of the crisis will be the subject of much debate, but we focus in this Article not on root causes, but the government response. For preliminary analysis on the origins of the crisis, see RICHARD A. POSNER, A FAILURE OF CAPITALISM: THE CRISIS OF '08 AND THE DESCENT INTO DEPRESSION (2009); Yuliya Demyanyk \& Otto Van Hemert, Understanding the Subprime Mortgage Crisis (Dec. 5, 2008), http://papers.ssrn.com/sol3/papers.cfm?abstract_id=1020396; Gary Gorton, The Panic of 2007 (Aug. 4, 2008), http://www.kc.frb.org/publicat/sympos/2008/Gorton.08.04.08.pdf. 
uncertainly, and finally on an emergency and massive basis.

What, exactly, was the government trying to do to respond to the crisis? Observers will differ on the quality and wisdom of its actions for years to come, but we think that its response to the financial crisis was driven by the legal constraints on the government institutions that handled the crisisand by the creative, and principally transactional, ways that the government managed those legal constraints. As the crisis developed, the government forced the sales of one of the five largest investment banks, the largest thrift in the country, and a number of consumer banks. ${ }^{3}$ It permitted an even larger investment bank and another of the country's largest thrifts to fail. The government also took over the country's largest insurer and nationalized the two government-sponsored enterprises that mortally suffered from the popping of the housing bubble.

When these efforts failed to prevent a cascading "run" on financial institutions, the government decided, in the course of less than a month, to create through congressional action an unprecedented $\$ 700$ billion asset purchase program. The government then turned this authorization into a massive investment in the country's largest financial institutions. It capstoned the investment by forcing the nation's nine largest remaining financial institutions to accept $\$ 125$ billion of government equity - a partial nationalization which the United States had never seen before. Nor did the government stop there. It flooded the global markets with liquidity and entered the commercial paper market on a massive scale. And the bailouts would continue with the rescue of Citigroup and Bank of America, two of the nation's largest financial institutions. These actions would mark the largest government economic intervention in history, and left former Treasury Secretary Henry M. Paulson Jr., Federal Reserve Board Chair Ben S. Bernanke, and former President of the Federal Reserve Bank of New York and current Treasury Secretary Timothy Geithner, the apparent leaders of this government effort, in control of much of the financial economy.

Although the government never, throughout this period, acted as if it felt very constrained by the law that limited its actions, we think that its legal constraints help to explain a great deal of the government response. For example, even though the crisis first evinced itself in the struggles of Bear Stearns, an investment bank overseen by the Securities and Exchange Commission (SEC), it was the Board of Governors of the Federal Reserve

3. The forced sale of Washington Mutual's assets and its subsequent bankruptcy was the nation's largest bank failure to date. See David Ellis \& Jeanne Sahadi, JPMorgan Buys 
System (Federal Reserve) that failed that bank and forced its sale, with the Treasury Department participating in the process. The other big financial institution collapses that preceded the government's implementation of the Emergency Economic Stabilization Act of 2008 (EESA) ${ }^{4}$ were largely coordinated by the Treasury Department and the Federal Reserveregulators who did not manage these institutions. These government agencies acted because they had the resources and the flexible legal authority to do so, while they concluded that the primary supervisors of the collapsing institutions were at best unnecessary and at worst helpless in the face of the looming crisis.

We think that the government's novel efforts during the financial crisis can be usefully analyzed in two ways. First, the government has been doing deals - the sorts of deals that it usually leaves to the private sector. ${ }^{5}$ The dealmaking ethos permeated even the staffing of the government's response-its financial crisis team was comprised largely of investment bankers, led primarily by Secretary Paulson, a veteran dealmaker who served as the Chief Executive Officer (CEO) of Goldman Sachs Group, Inc. ${ }^{6}$ In this Article, we show how these deals were done and how the government stretched, and in some cases appeared to overstretch, its legal authority to make those deals happen. Second, the government, as a matter of administrative law, has been exploring the outer limits of its permissible authority in what it views as a time of crisis and, in so doing, conducted the management of the crisis through the two institutions least constrained by the law-the Treasury Department and the Federal Reserve. We analyze how the government's response both pushed and was shaped by the law at its disposal.

Doing deals and aggressively reinterpreting regulatory authority are not unrelated activities. Dealmakers use contract to avoid some legal

4. Pub. L. No. $110-343,122$ Stat. 3765 (to be codified at 12 U.S.C. $\S 5201$ ).

5. We think the recent deals depart from prior Federal Reserve practice in particular because of the size of the deals and the expansion of Federal Reserve authority into new deals, as well as the prominent, and relatively unprecedented, role played by dealmakers in the Treasury Department. The Federal Reserve has, of course, organized the purchase of failed banks by other banks in the past, however; it has just done so more rarely than it did here.

6. See Aleksandrs Rozens, Great Expectations: Vanguard Founder Talks About the Current Market, Speculation and How Investors Need to Adjust Their Expectations, INVESTMENT DEALER's Digest: IDD, Nov. 17, 2008 (discussing Secretary Paulson's investment banking background and its influence on his reaction to the financial crisis). For an inside analysis of Treasury's response to the crisis, Philip Swagel's post hoc analysis is interesting, albeit not entirely disinterested (he was a Treasury official during the crisis). See Philip Swagel, The Financial Crisis: An Inside View, Brookings Papers on Economic Activity (Spring 2009), available at http://www.brookings.edu/economics/bpea/ /media/Files/Programs/ES/BPEA/2009_spring _bpea_papers/2009_spring_bpea_swagel.pdf. 
constraints and often prefer to focus on arms-length negotiation, rather than regulatory authorization, as the source of legitimacy for their actions. We think that one useful way to characterize the government's role would be as that of an extraordinarily vigorous dealmaker, with some of the bad, as well as good, implications of governance by deal. For example, the early set of deals concluded by the government's team were done on tough terms for their targets; the government as "buyer" maximized its leverage over distressed institutions. Sometimes the government walked away from the table-as it did with Lehman Brothers-an act that dealmakers often do to bolster their reputation for future deals. And the government often acted in this phase of the crisis as dealmakers do-conclude it, forget it, and move on to the next deal. But when the government's deal-to-deal response appeared to be failing, the Treasury Secretary, at the urging of the Chairman of the Federal Reserve, decided that it needed a more comprehensive and systematic approach to preventing systemic fallout from the collapse of the housing bubble as well as the continuing and speeding collapse of the financial economy. ${ }^{7}$ This holistic approach was planned as one kind of deal, where the government would purchase distressed assets from financial institutions, and turned into another kind of deal, where the government purchased sizable stakes in these financial institutions instead of buying their hard-to-price-and-sell troubled assets.

All of this suggests at least a weak sort of process consistency in the government response to the crisis. This is a consistency that many observers have concluded that the government has lacked; and to be sure, we agree with Richard Posner that there were "a series of improvisations" in the government's actions. ${ }^{8}$ But perhaps this unusual consistency also offers a coherent explanation of the government's apparently incoherent response to the crisis. Dealmakers of the investment-banker variant, after all, do not much care about the consistency between deals. In the process they decide quickly, negotiate hard, consider transaction and other costs to the best they can, and then call it a day. ${ }^{9}$ Moreover, although contract, securities, corporate, and other forms of law play an important role in deals, strict legal compliance has never been the principal focus of the dealmaker. Rather, risks and legal constraints must be weighed against each other in pursuit of the ultimate private goal-a completed deal. That perspective,

7. Jon Hilsenrath et al., Paulson, Bernanke Strained for Consensus in Bailout, WaLL ST. J., Nov. 10, 2008, at Al.

8. Posner, supra note 2, at 329.

9. This dealmaking persona was one that people commonly used to describe Secretary Paulson. See, e.g., Posting of Heidi N. Moore to Deal Journal, http://blogs.wsj.com/deals/2008/09/21/is-hank-paulson-too-powerful/ (Sept. 21, 2008, 21:34 EST). 
too, characterized the government's response to the crisis. Time and again, the government structured deals that pushed its legal authority to the very edge and beyond in pursuit of, and bound by, its own political, economic, and, perhaps, sociological interests.

To be sure, that legal authority made a difference with how the government structured its deals. It did so largely through the Federal Reserve, to begin with, because that agency had the resources and regulatory flexibility to serve in that role. But the Federal Reserve's legal authority was stretched as far as possible as these deals evolved. And again, here the government acted as dealmakers do-structuring the latest deal with a view toward precedent from prior transactions but willing to deviate as circumstances dictated. In the first three parts of our Article, we analyze just what the government did when it chose to act by deal.

We then turn in the final part of our Article to an evaluation of the government's approach and its implications for legal scholarship. For example, while administrative law scholars spend much of their time thinking about how the D.C. Circuit and Supreme Court might review government administrative decisions, it is worth noting that the response to the financial crisis has had nothing to do with the courts. Instead, it has been concentrated entirely in the Executive Branch and independent agencies-although aficionados of presidential control will have a difficult time identifying any particularly important presidential role in the construction and implementation of the bailout, which appears to have been conducted by the Treasury Secretary and Chairman of the Federal Reserve with some congressional blessing. Nor can one find much of a role for states in this epic corporate reorganization and insurance crisis, even though state law is the basis of corporate and insurance regulation.

But if courts and states are the missing players in the administrative law paradigm, the new process of regulation by deal exemplifies regulatory trends that are more familiar and increasingly important. In adopting a form of policymaking unlikely to be subject to judicial review (especially before congressional passage of the EESA), the government adopted a new governance model of administration, one exemplified, as many other moreprosaic initiatives are, by public-private partnerships and regulatory action positioned outside of the range of judicial review. Government by deal is not open government, and it rejects some of the usual values of administrative law, such as predecision notice to affected parties and the public; measured, unhasty action; and comment-ventilated policymaking.

Perhaps most interestingly, even as the regulation-by-deal paradigm semi-nationalized some traditional private financial services in the United States, it also contributed to the privatization of government functions, which, during this period, were in many ways "run like a business" rather 
than as a regulator. The government was doing deals and taking stakes in profit-making institutions. ${ }^{10}$ In this way, government by deal is not wholly unlike the government reinvention that analysts ranging from Tom Peters to Al Gore have urged on it. ${ }^{11}$

Moreover, this study informs dealmaking theory. The deals the government and its lawyers structured reaffirmed the limitations of dealmaking and deal lawyering. Dealmaking is a path-dependent process-lawyers and transaction participants rely upon network and signaling effects, structuring the current deal on the basis of the old one to advantage themselves with the benefits of prior precedent and to illustrate their capability. ${ }^{12}$ But lawyers can overrely on this precedent to forgo innovation, resulting in an agency cost that injects inefficiencies into the dealmaking process. These inefficiencies are reinforced by the transaction costs of lawyering in high-pressure, time-sensitive environments, which can result in drafting mistakes and other errors. ${ }^{13}$ In structuring bailouts these principles were ably on display. The quick time frames of the government's deals resulted in both mistakes and unintended consequences. Moreover, even though lawyers and participants were freed from the bounds of prior precedent, they still looked to that precedent to structure deals. But this account also shows the beauty of dealmaking and the circumstances under which innovation can occur. Despite the errors, innovation was a stronger force than normal, showing the potential of lawyers and dealmakers to create more internally efficient structures when they are not constricted by normal agency and signaling costs. We also

10. The government even went so far as to hire a team of sophisticated investment bankers, lawyers, and asset managers to assist it in implementing the EESA.

11. See Al Gore, From Red Tape to Results: Creating a Government that WORKS BETTER AND COSTS LESS (1993), available at http://govinfo.library.unt.edu/npr/library/nprrpt/annrpt/redtpe93/index.html (follow "introduction" hyperlink). For an overview of the Peters approach to management, see Thomas J. Peters \& Robert H. Waterman, Jr., In Search of Excellence: Lessons FROM AMERICA's BEST-RUN COMPANIES (1982).

12. See Steven M. Davidoff, The Failure of Private Equity, 82 S. CAL. L. REV. 481 (2009); see also Marcel Kahan \& Michael Klausner, Standardization and Innovation in Corporate Contracting (or "The Economics of Boilerplate"), 83 VA. L. REV. 713, 729-36 (1997). For a discussion of what exactly path dependency is and its detractors, see Paul A. David, Path Dependence, Its Critics and the Quest for 'Historical Economics,' in Evolution and Path Dependence in Economic IdeAs: Past and Present 15 (Pierre Garrouste \& Starvos Ioannides eds. 2001). For a more skeptical view, see STAN J. Liebowitz, Re-THINkING THE NeTWORK ECONOMY: THE TRUE ForCes that DRive the Digital MARKETPLACE (2002).

13. See Davidoff, supra note 12. For a further discussion of the deal lawyer as creating value net of legal fees through his or her efforts, see Ronald J. Gilson, Value Creation by Business Lawyers: Legal Skills and Asset Pricing, 94 YALE L.J. 239, 243 (1984). See also Claire A. Hill, Why Contracts Are Written in "Legalese," 77 CHI.-KENT L. REV. 59, 71 (2001). 
explore the implications of the deal paradigm the government choseventure capital instead of private equity-even though it appeared that the sort of fundamental restructuring, and often shrinking, promised by private equity was a better fit for the government, taxpayers, and, perhaps, market stability.

It is worth observing that the government has concluded distressed deals before-indeed, the underused "prompt corrective action" regime is premised on these sorts of distressed deals. ${ }^{14}$ And governments have increasingly participated as market actors--sovereign wealth funds are an example - though our government rarely does so. Governments, though again, not the government of the United States, have nationalized firms and industries before. But this regulation by deal is new, and it is new in size, scale, and scope.

Our account is a preliminary one, and it is meant to provide a basis for further explaining what, precisely, the government did as a matter of law, and an evaluation of whether what it did worked. It is too soon to pass a final judgment on the empirical soundness of the government's strategy or to adjudge its use of the law as comprehensively good or bad. ${ }^{15}$ What we do here is show precisely how the government's response was constrained by the law as it existed when the crisis hit and how it used the law it had, rather than the one it needed, culminating in the decision to seek further authority from Congress and then quickly reinterpreting that authority to make more deals.

In what follows, we evaluate the government's response to the crisis through a blow-by-blow, or historical, account. The gathering crisis pushed the government to rely on its traditional tools of economic control and financial regulation as it began to spread. Once Bear Stearns failed, those tools were abandoned and bailouts-or deals-became the new norm. We analyze each deal or nondeal in some detail and then dissect the bailout statute itself and the way the government interpreted, and then reinterpreted, it. Finally, we analyze the actions of the all-too-maligned SEC, as well as the other agencies involved in the government's deals. The result is a comprehensive review of the government's actions during the financial crisis. In doing so, we hope to inform and guide the coming legal debate about the validity of the government's actions and any future regulatory reform.

14. That regime was created by the Federal Deposit Insurance Corporation Improvement Act of 1991, 12 U.S.C. $\S 183 \ln (\mathrm{a})(\mathrm{C})$ (2006).

15. But see CONG. OVERSight PANel, ACCOUNTABILITY for the Troubled Asset RELIEF PROGRAM (2009), available at http://financialservices.house.gov/TARP.html (examining whether the Troubled Asset Relief Program expenditures were justified and prudent). 


\section{THE GOVERNMENT IN CRISIS}

\section{A. Before the Crisis: The Macroeconomic Government}

The first hints of public trouble in the credit markets began to emerge from the subprime mortgage market in April 2007. On April 2, 2007, New Century Financial, a leading subprime lender, filed for bankruptcy. ${ }^{16}$ Other lenders involved in this industry began to experience difficulties due to disruptions in the housing and mortgage markets. ${ }^{17}$ At first, the trouble seemed to be confined to these markets, and between April and August 2007 lenders in the general credit market, including the leveraged loan market, continued to extend credit on generous terms. ${ }^{18}$ But in early August 2007, the difficulties in the subprime mortgage market spread unevenly into the general credit and equity markets. In the month of August, the Standard \& Poor's (S\&P) 500 Index declined $13 \%,{ }^{19}$ the Chicago Board Options Exchange Volatility Index, an index measuring market volatility, peaked at $37.5 \%,{ }^{20}$ and the broader credit markets began to freeze up as lenders became wary of extending additional credit. ${ }^{21}$ One sign of the tightening in the credit markets was an August spike in the overnight dollar London Interbank Offered Rate (LIBOR), the rate at which banks loan money to one another on an overnight basis, to $5.59 \%{ }^{22}$

The Federal Reserve's response to the initial stages of this crisis was a traditional one designed to relubricate the credit markets. In the period from August 2007 to March 1, 2008, the Federal Reserve steadily lowered the target rate for federal funds in that period from $4.75 \%$ to $2.25 \%{ }^{23}$ and

16. Julie Creswell \& Vikas Bajaj, Home Lender Is Seeking Bankruptcy, N.Y. Times, Apr. 3, 2007, at C1.

17. See Vikas Bajaj, A Cross-Country Blame Game, N.Y. Times, May 8, 2007, at Cl .

18. For example, on July 12, 2007, Deutsche Bank and Credit Suisse agreed to extend up to $\$ 15$ billion in debt financing for the entire purchase price agreed to be paid by Hexion for Huntsman Corporation. This was a sizable commitment by the banks and permitted Hexion to finance the entire purchase price for Huntsman. See Press Release, Hexion Specialty Chem., Inc., Hexicon Specialty Chemicals, Inc. to Acquire Huntsman Corporation for $\$ 28.00$ Per Share in Cash (July 12, 2007), http://www.hexion.com/news_article.aspx?id=1531.

19. See Gregory Zuckerman \& Craig Karmin, Hedge Funds Get Rattled as Investors Seek Exits, Wall St. J., Sept. 6-7, 2008, at B1.

20. See Chicago BD. Options Exchange, 2008 Historical Data (2009), http://www.cboe.com/micro/vix/historical.aspx (follow "New methodology: VIX data for 2004 to present" hyperlink).

21. Greg Ip, Fed Cut Aims to Contain Damage: Stocks Soar as Bernanke Tackles Credit Crunch with Half-Point Move, WALL ST. J., Sept. 19, 2007, at A1.

22. August 2007 LIBOR rate data is available from the British Bankers' Association. BRITISH BANKERS' ASS'N, 2007 HISTORIC LIBOR RATES, http://www.bba.org.uk/bba/jsp/polopoly.jsp?d=141\&a=11947 (follow "historic BBA Libor rates" hyperlink, then select "2007 Historic Libor Rates" internal link).

23. FED. RESERVE BD., OPEN MARKET OPERATIONS (2008), 
the discount rate from $5.75 \%$ to $3.25 \%{ }^{24}$ The Federal Reserve's action was book-ended by an equally traditional federal government response aimed at consumers. On February 13, 2008, the President signed the Economic Stimulus Act of 2008 (Stimulus Act), which provided for tax rebates to citizens and legal residents of the United States in an aggregate amount of $\$ 100$ billion. $^{25}$

Notably, the Stimulus Act also provided for a temporary increase on the limits for conforming loans that Fannie Mae and Freddie Mac could purchase to include many jumbo mortgages originated between July 1, 2007, and December 31, 2008. ${ }^{26}$ The government response to the real estate crisis, the root cause of the economic disruption, was otherwise limited largely to the HopeNow initiative, a voluntary program to encourage loan modifications for borrowers experiencing financial difficulty in repaying their mortgages. ${ }^{27}$

In the fall of 2007 the stock markets recovered, and the S\&P 500 Index hit an all-time high on October $9 .^{28}$ The credit markets also began to liberalize in October and November. ${ }^{29}$ From October 1 to November 30, the overnight LIBOR rate declined to $4.72 \%{ }^{30}$ But the real estate crisis continued, as property prices continued to decline, and financial institutions, particularly those exposed to the subprime lending market, began to recognize that many mortgage holders would be unable or unwilling to pay off their debts, forcing banks into enormous write-downs of mortgage-related assets. ${ }^{31}$

Financial institutions at first turned to market solutions to shore up their

http://www.federalreserve.gov/fomc/fundsrate.htm.

24. Fed. Reserve Discount Window, Historical Discount Rates: Primary and SECONDARY CREDIT (2008), http://www.frbdiscountwindow.org/historicalrates.cfm?hdrID=20\&dtlID (follow "Primary and Secondary Credit" hyperlink).

25. Economic Stimulus Act of 2008, Pub. L. No. 110-185, 122 Stat. 613 (to be codified at 26 U.S.C. $\S 6428$ ). For an early study of the efficacy of this program, see Christian Broda \& Jonathan Parker, The Impact of the 2008 Tax Rebates on Consumer Spending: $\begin{array}{llll}\text { Preliminary Evidence 2008), } & \text { (July }\end{array}$ http://online.wsj.com/public/resources/documents/WSJ-2008StimulusStudy.pdf.

26. Economic Stimulus Act of 2008, Pub. L. No. 110-185, $\S \S 201,202,122$ Stat. 619, 619-21 (2008).

27. For details of the HopeNow program, see HOPE NOW, Support \& Guidance for Homeowners, http://www.hopenow.com/ (last visited Apr. 19, 2009). See also Ruth Simon, Some Borrowers Rescued: Over 1 Million Got Help to Keep Homes; Foreclosures Rising, WALL ST. J., Mar. 4, 2008, at A3.

28. Peter A. McKay, Dow and S\&P Hit Records on Fed's View, Wall St. J., Oct. 10, 2007, at C1. C4.

29. Vikas Bajaj, Investors Divided on the Fed's Rate Cut, N.Y. TIMES, Nov. 1, 2007, at

30. BRITISH BANKERS' Ass'N, supra note 22.

31. See Posner, supra note 2 , at 66-68. 
balance sheets. In the period from December 2007 through February 2008, financial institutions, along with other publicly traded companies, undertook a massive recapitalization, globally raising $\$ 155.1$ billion in new capital from investors. ${ }^{32}$ Sovereign wealth funds were the largest single investors, supplying $\$ 24$ billion of the total domestic investment and creating some consternation over the increasing prominence of these foreign investors. ${ }^{33}$ For a time, the stock market continued to trade near its fall 2007 highs. ${ }^{34}$ However, the relatively stable equity markets hid turmoil in the credit markets as banks continued to struggle under the weight of the housing crisis and mortgage-related assets on their balance sheets. The U.S. economy was undergoing something new-a credit-driven rather than equity-driven market correction.

Then Bear Stearns almost collapsed.

\section{B. The Preliminary Stage: The Government as Deal Facilitator}

\section{The Lessons of Bear Stearns}

As of March 2008, Bear Stearns, an institution that had survived eighty years of Wall Street upheavals, was in a battered but -at least in the view of its executives - unbowed state. The battering was clear enough. In June 2007 two hedge funds, which were advised by Bear and created to invest in subprime mortgage-related assets and had an estimated $\$ 1.5$ billion in assets at year-end of 2006 , had become insolvent. ${ }^{35}$ Their failure required Bear to commit $\$ 3.2$ billion in a vain attempt to stabilize the funds and made market participants particularly wary of the investment bank's

32. The figure was obtained by searching the Capital IQ database for private or public offerings made by firms in the Financials (primary) sector between December 1, 2007, and March 1, 2008.

33. Hearing Before the Subcomm. on Domestic and International Monetary Policy, Trade, and Technology and the Subcomm. on Capital Markets, Insurance, and Government Sponsored Enterprises of the H. Comm. on Financial Services, 110th Cong. (2008) (statement of Scott G. Alvarez, General Counsel, Board of Governors of the Federal Reserve System).

34. Michael M. Grynbaum, Discussion of a Fed Cut Only Stirs Up Concerns About a Weak Economy, N.Y. TIMES, Jan. 3, 2008, at Cl. The market indexes were down about $10 \%$ on the year by January 23 , rebounding slightly at the end of the month when the S\&P 500 reached 1,355.81. See Edmund L. Andrews, Fed, in Surprise, Sets Big Rate Cut to Ease Markets, N.Y. TIMES, Jan. 23, 2008, at A1; Michael M. Grynbaum, Rally Sputters in LateDay Sell-Off, N.Y. TIMES, Jan. 31, 2008, at C13. The indexes recovered slightly in February with the S\&P closing out the month at 1,380.02. See Peter A. McKay \& Joanna Slater, Markets Wind Up in a Draw as Economic Arrows Flutter, WALl ST. J., Feb. 28, 2008, at $\mathrm{C} 1$.

35. See Gretchen Morgenson, Bear Stearns Says Battered Hedge Funds Are Worth Little, N.Y. TIMES, July 18, 2007, at C2; Randall Smith, Holders in Two Funds Want to Replace Bear, WALL ST. J., Sept. 5, 2007, at C2. 
exposure to mortgage-related assets. ${ }^{36}$ Moreover, Bear was the most highly leveraged of the five large investment banks with an approximate 33:1 debt-to-equity ratio. ${ }^{37}$ Bear was considered to have the largest exposure to mortgage-related assets; the bank had already taken $\$ 1.9$ billion in writedowns related to its ownership of these types of assets in the fourth quarter of $2008 .^{38}$ But the news was not all bad. At the beginning of March, Bear's secured debt was rated investment grade by Standard and Poor's. ${ }^{39}$ On March 7, 2008, its stock price closed at $\$ 70.08$ per share; this was far down from its all-time high of $\$ 171.51$ in January 2007 , to be sure, but the market was not predicting Bear's collapse. ${ }^{40}$

JPMorgan's government-facilitated acquisition of Bear would turn out to be only the first of the government's deals during the market crisis. However, this first deal established a number of principles that would guide the government through the crisis. It is worthwhile to set forth these lessons before we glean them from the facts of the Bear acquisition.

First, in this initial stage, the government was hesitant to act but would do so when left with no other perceived choice. The criteria forcing the government to act would be vague, but mainly was the "too big to fail" doctrine. Institutions whose failure came too quickly or otherwise would imperil the soundness of the entire financial system would be salvaged. But here the government was picayune in its decisions, seemingly willing to save Bear but later permitting the larger Lehman Brothers to fail. We believe that Lehman was allowed to fail despite its larger size because of an overriding need for the government to appear to be a strong dealmaker willing to walk away-a position that the government felt was possible because the market had had a longer time to prepare for a Lehman downfall than a Bear one. This need was reinforced by the political and legal constraints upon the federal government, which further prevented it from saving Lehman Brothers.

Second, when acting to save an institution in the initial phase, the government looked first to penalize shareholders, but not bondholders, in a

36. Julie Creswell \& Vikas Bajaj, \$3.2 Billion Move by Bear Stearns to Rescue Fund, N.Y. TIMES, June 23, 2007, at Al.

37. It was exactly 32.8:1. Bear Stearns Cos., Annual Report (Form 10-K), exhibit 13 (Financial Report), at 52 (Jan. 29, 2008), http://www.sec.gov/Archives/ edgar/data/777001/000091412108000077/0000914121-08-000077.txt. at $\mathrm{A} 1$.

38. Kate Kelly, Cayne to Step Down as Bear Stearns CEO, WaLL ST. J., Jan. 8, 2008,

39. Bear Stearns had a credit rating of AAA until March 14, 2008, when S\&P cut its long-term rating by three notches to BBB. See Min Zeng, Prices of Treasurys Rise in Safety Move, WALL ST. J., Mar. 15-16, 2008, at B3.

40. See Andrew Ross Sorkin, In Sweeping Move, Fed Backs Buyout and Wall St. Loans, N.Y. TIMES, Mar. 17, 2008, at A1; NYSE Quotes, WALl ST. J., March 8-9, 2008, at B6. 
proclaimed fight against moral hazard. Directors were not directly targeted and officers only intermittently penalized. In the Bear Stearns deal, the government actually permitted JPMorgan to indemnify Bear's officers and directors and otherwise did not act to forestall any arrangements between JPMorgan and Bear's current officers to work at JPMorgan after the merger. Again, this may have been a bow to legal limitations as the government required the nominal cooperation of the Bear board of directors to arrange this bailout.

Third, the government insisted that market solutions be largely foreclosed for the sake of achieving orderly ones. In the Bear deal, the possibility that J.C. Flowers could pay more or otherwise find further financing to acquire Bear was halted by the government's insistence that an acquirer be found within an extremely short time frame. But ultimately, the government was bound by the law in its preferences, as the government found out when its attempt to arrange for Citigroup to acquire Wachovia's bank depositary assets was thwarted by Wells Fargo's timely bid. Wells Fargo exploited a legal opening to arrange its own trumping acquisitionone that the government went along with due to legal constrictions and its overriding preference for ordered solutions.

Finally, the government was willing to stretch the law and flex its authority where it could, but was not willing to boldly violate the law. The government used $\S 13$ of the Federal Reserve Act to buy time for the Bear deal. Then, the government assisted in structuring the transaction to meet these timing needs and prevent Bear's shareholders from forestalling the deal. In doing this the government likely facilitated the stretching, if not breaking, of Delaware corporate law. But still, the government could not fully penalize Bear's shareholders as it wanted to. Instead, it was ultimately limited by the law it could not break - the requirement for a vote, which led to Bear's shareholders achieving some recompense. The government's ultimate purpose was to conclude the deal as quickly as possible; if it could not fully implement its goals in order to do this, like any dealmaker, it would accept such restrictions.

Yet, the quick failure of Bear Stearns and the government's seeming unpreparedness was a key theme that would later come to the forefront. The government's actions were reactive rather than proactive. Moreover, the government was building a case of free riding-institutions now knew that if they were too big to fail the government would help them and market solutions would disappear. Nonetheless, Bear set a deal pattern, one that would emerge and affect future bailouts. 


\section{The Fall of Bear Stearns}

The near-bankruptcy of Bear Stearns unfolded extraordinarily quickly. It began on Monday, March 10, 2008, when rumors began to spread in the market that a major investment bank had rejected a standard $\$ 2$ billion repurchase loan request from Bear Stearns. ${ }^{41}$ From there, rumors began to increasingly spread that Bear Stearns was about to become insolvent and otherwise was in some type of financial difficulty. Counterparties became hesitant to trade with Bear and otherwise demanded collateral for their preexisting and future trades, and asset managers, such as hedge funds, began to move funds to other financial institutions. ${ }^{42}$ Bear's fall set a precedent for the decline of other financial institutions. Throughout the crisis, rumors of a financial institution's imminent collapse would become reality through a self-fulfilling feedback loop as market participants lost confidence in the unfortunate institution, demanding collateral, withdrawing assets, and refusing to do business with the suspect institution.

During this period, the SEC concluded that Bear Stearns was adequately capitalized. As the SEC would later admit,

Bear Stearns' registered broker-dealers were comfortably in compliance with the SEC's net capital requirements, and in addition ... Bear Stearns' capital exceeded relevant supervisory standards at the holding company level.... This was consistent with what the SEC had seen over the preceding weeks, during which SEC staff-both on-site and at headquarters-monitored the capital and liquidity positions of all the CSEs, in the case of Bear Stearns on a daily basis. ${ }^{4}$

Bear's counterparties and prime brokerage clients disagreed. By Thursday night Bear's liquid reserves had dropped from $\$ 18.3$ billion the week before to $\$ 5.9$ billion, and it owed Citigroup $\$ 2.4$ billion. $^{44}$ More perilously, Bear required daily financing of approximately $\$ 75$ billion to function. These funds were obtained in the daily short-term repurchase (repo) market, with Bear putting up collateral assets in exchange for cash liquidity. On Thursday morning, Bear was unable to obtain approximately $\$ 20$ billion of the $\$ 75$ billion required. ${ }^{45}$ The rapid decline of Bear's liquidity showed the perils of using short-term repo lending for liquidity

41. Roddy Boyd, The Last Days of Bear Stearns, ForTUNE, Apr. 14, 2008, at 89.

42. See Brett Philbin \& Rob Curran, Boeing Rides Higher, but Bear Struggles, WALL ST. J., Mar. 14, 2008, at C5; see also Kate Kelly, Fear, Rumors Touched Off Fatal Run on Bear Stearns, WALL. ST. J., May 28, 2008, at Al.

43. Press Release, SEC, Chairman Cox Letter to Basel Committee in Support of New Guidance on Liquidity Management (Mar. 20, 2008), http://sec.gov/news/press/2008/200848.htm.

44. Kelly, supra note 42.

45. See William D. Cohan, House of Cards: A Tale of Hubris and Wretched EXCESS ON WALL STREET 47-53 (2009). 
purposes. These funds could disappear at any time if the sophisticated lenders providing them became unwilling to lend. When that happened on Thursday, March 13, Bear concluded that without outside assistance it would have to file bankruptcy the next day. ${ }^{46}$ In the course of the Thursday night, the Federal Reserve Bank of New York (New York Federal Reserve) decided to guarantee a twenty-eight-day loan from JPMorgan to Bear in the amount of $\$ 30$ billion. $^{47}$

This particular government action also set a precedent: it was done through a Federal Reserve institution via the legal authority that would be used for each of the government's ad hoc bailouts (as well as a number of other moves designed to inject liquidity into the financial markets). For the legal authority to make this loan, the Federal Reserve relied upon the broad language of its discount window authority, $\S 13$ of the Federal Reserve Act, a law that was last invoked to the benefit of nonbanks in the Great Depression. ${ }^{48}$ The pertinent part of $\S 13$ reads,

In unusual and exigent circumstances, the Board of Governors of the Federal Reserve System, by the affirmative vote of not less than five members, may authorize any Federal Reserve bank... to discount for any individual, partnership, or corporation, notes, drafts, and bills of exchange when ... indorsed or otherwise secured to the satisfaction of the Federal Reserve bank: Provided, [t]hat before discounting ... the Federal Reserve bank shall obtain evidence that such individual, partnership, or corporation is unable to secure adequate credit accommodations from other banking institutions. $^{49}$

This section, which would form the basis of the government's response to a number of other bailouts, provides the Federal Reserve the right to make loans to, as the Federal Reserve interpreted it during the crisis, any

46. See Hearing Before the S. Joint Economic Comm., 110th Cong. (2008) (statement of Ben S. Bernanke, Chairman, Board of Governors of the Federal Reserve System), http://jec.senate.gov/index.cfm?FuseAction=Hearings.HearingsCalendar\&ContentRecord_i

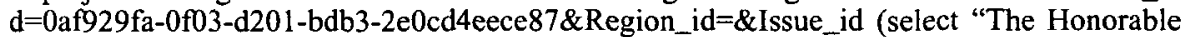
Ben Bernanke, Chairman of the Federal Reserve" hyperlink).

47. See Bear Stearns Cos., Current Report (Form 8-K) (Mar. 16, 2008), http://www.sec.gov/Archives/edgar/data/777001/000091412108000249/bel 2284854-8k.txt; see also Hearing Before the S. Comm. on Banking, Housing and Urban Affairs, 110 th Cong. (2008) (statement of Timothy F. Geithner, President and Chief Executive Officer, Federal Reserve Bank of New http://banking.senate.gov/public/index.cfm?FuseAction=Hearings. Testimony\&Hearing_ID = ec013d8f-fele-4fb6-a514-ab93be32ad38\&Witness_ID=b428e0eb-d844-4add-9d85-8fab78b a065a (select "viewfile" hyperlink).

48. Press Release, Fed. Reserve Bank of N.Y., Summary of Terms and Conditions Regarding the JPMorgan Chase Facility (Mar. 24, 2008), http://www.newyorkfed.org/newsevents/news/markets/2008/rp080324b.html; see also Greg Ip, Central Bank Offers Loans to Brokers, Cuts Key Rate, WALL ST. J., Mar. 17, 2008, at Al.

49. 12 U.S.C. $§ 343(2006)$. 
financial institution. In addition, it would also turn out that the Federal Reserve would have substantial leeway in setting the interest rates for these loans. This is because $\S 14(\mathrm{~d})$ authorizes the Federal Reserve to fix the rates for loans under this section "with a view of accommodating commerce and business." 50 The so-called discount window was open to virtually anyone, at least as far as its text went, even if decades of practice suggested otherwise. The only condition was that a supermajority of Federal Reserve board members agree that the circumstances were indeed "unusual and exigent." This meant that, in exchange for the inexpensive money, the recipient had to establish that it had sought credit elsewhere and make the loan "secured to the satisfaction" of the Federal Reserve. 51

Moreover, in administering the discount window and providing assistance to banks, the Federal Reserve's actions are effectively removed from judicial review. While no court has held that Federal Reserve decisions are unreviewable as a matter of law, courts have steered clear of substantively reviewing both monetary policy decisions and bank financial assistance. In Raichle v. Federal Reserve Bank, Judge Augustus Hand concluded that there was nothing inappropriate with a legally constituted bank making loans to other banks and setting interest rates for those loans. $^{52}$ And after the Franklin National Bank failed in 1974 and the Federal Reserve provided financial assistance, the Second Circuit concluded that

[a]bsent clear evidence of grossly arbitrary or capricious action on the part of [the Federal Reserve or the Treasury Department] ... it is not for the courts to say whether or not the actions taken were justified in the public interest, particularly where it vitally concerned the operation and stability of the nation's banking system. 53

Thus, the Federal Reserve, through its New York subordinate, acted in a novel manner and with relative impunity in providing this backstop guarantee to assist Bear Stearns. In later testimony, Chairman Bernanke would offer the reason. He stated that this guarantee was necessary in order to forestall the bankruptcy of Bear-an event which he asserted would have systemic ramifications and cause widespread, perhaps

50. Id. $\S 357$.

51. Id. $\S 343$. The Federal Reserve and Treasury Secretary have since suggested that this security requirement actually constrains the flexibility of the central bank in opening the discount window--but since the collateral requirement is left up to the Federal Reserve's discretion, these claims seem like disingenuous efforts to argue for a limitation on the power of the bank where there is none. See, e.g., Posting of David Zaring to Conglomerate, http://www.theconglomerate.org/2008/10/must-the-fed-ta.html (Oct. 15, 2008).

52. 34 F.2d 910, 913 (2d Cir. 1929).

53. Huntington Towers, Ltd. v. Franklin Nat'l Bank, 559 F.2d 863, 868 (2d Cir. 1977). 
catastrophic domino losses in the financial market. ${ }^{54}$

But the government appeared to sour on the idea of saving Bear quickly and turned to a preselected partner in the private sector to do the job. Secretary Paulson informed Bear that the Federal Reserve would terminate the guarantee and loan in seventy-two hours, leaving Bear to find an alternative transaction by that time or declare bankruptcy. ${ }^{55}$ The reasons for the government's reversal of course on Bear still remain somewhat murky, but the next move by the government was less so. ${ }^{56}$ It apparently already had an idea about an acquirer for Bear.

There were two prospective bidders-JPMorgan and a consortium of private equity firms led by J.C. Flowers. The Federal Reserve and the Treasury Department, which were both actively involved in structuring this bailout, were unwilling to commit to providing the approximately $\$ 20$ billion in financial assistance J.C. Flowers required to make an acquisition, essentially locking the J.C. Flowers group out of the process. $^{57}$ Furthermore, Treasury pushed JPMorgan to offer as low a price as possible for Bear, a company that on Friday had closed at $\$ 30$ a share and the prior Monday had closed at $\$ 70$ a share. Under Secretary of the Treasury Robert Steel would later testify that Secretary Paulson encouraged this low price in order to again prevent future moral hazard by financial institutions. ${ }^{58}$ The

54. See Hearing Before the S. Joint Economic Comm., 110th Cong. (2008) (statement of Ben S. Bernanke, Chairman, Board of Governors of the Federal Reserve System), http://jec.senate.gov/index.cfm?FuseAction=Hearings.HearingsCalendar\&ContentRecord_i $\mathrm{d}=0 \mathrm{af9} 29 \mathrm{fa}-0 \mathrm{f03}-\mathrm{d} 201$-bdb3-2e0cd4eece87\&Region_id=\&Issue_id (select "The Honorable Ben Bernanke, Chairman of the Federal Reserve" hyperlink). It remains unclear whether this would have actually occurred. Bear Stearns's prime-brokerage business constituted $21 \%$ of the industry and its collapse may have left many hedge funds without collateral and assets leading to follow-on economic effects. Certainly these follow-on effects were apparent in the case of the failure of Lehman.

55. See Kate Kelly, Bear Stearns Neared Collapse Twice in Frenzied Last Days, WALL ST. J., May 29, 2008, at A1; Stephen Labaton, Bear Stearns in the Committee Room, N.Y. Times, Apr. 4, 2008, at C1.

56. Two explanations have been proffered. First, that the guarantee had failed to forestall Bear's clients from withdrawing funds and that Bear was going to default on the JPMorgan loan on Monday. By forcing Bear into a transaction, the Federal Reserve was protecting its guarantee and preventing any monetary loss. This is the story put forth by the Federal Reserve. See Hearing Before the S. Comm. on Banking, Housing and Urban Affairs, 110th Cong. (2008) (statement of Timothy F. Geithner, President and Chief Executive Officer, Federal Reserve Bank of New York), http://banking.senate.gov/ public/index.cfm?FuseAction=Hearings. Testimony\&Hearing ID=ec013d8f-fe le-4fb6-a514 -ab93be32ad38\&Witness_ID=b428e0eb-d844-4add-9d85-8fab78ba065a (select "viewfile" hyperlink). The second reason offered is a political one: that the Treasury Department, particularly Secretary Paulson, did not want to be seen as bailing out Bear and facilitating future moral hazard. Given that the threat to the financial system remained if Bear collapsed, it also remains unclear whether the government would have fulfilled its threat to cut off Bear if it did not find such a transaction. See Kelly, supra note 55.

57. See Cohan, supra note 45 , at 88 ; Kelly, supra note 55.

58. See Hearing Before the S. Comm. on Banking, Housing and Urban Affairs, 110 th 
chastened investment bank took the deal. ${ }^{59}$

\section{JPMorgan Acquires Bear Stearns}

The final $\$ 2$ a share price agreed to be paid by JPMorgan was punishing, but punishing acquisitions of publicly held corporations can, at least in theory, be voted down by the shareholders. The terms of the final merger agreement show that this was a substantial worry of the participants. In order to ensure that the Bear shareholders would not block this transaction, the lawyers hastily negotiated a number of innovative deal-protection devices designed to forestall this possibility. The resulting deal terms are interesting partly because the hastily concluded acquisition contained some surprises for the sophisticated lawyers and clients involved, and partly because some of the deal terms were flatly inconsistent with the Delaware law that governed the transaction. As we will see, the resulting government-provoked transaction became a deal that required still more government intervention to close.

The lawyers for both sides innovated to negotiate an acquisition with terms different than those normally utilized in strategic acquisitions in order to meet their unique purposes. Most prominently, Bear granted to JPMorgan an option to purchase an amount of common stock equal to $19.9 \%$ of Bear's outstanding common stock. The option was exercisable if Bear agreed to be acquired by a third party. The maximum compensation JPMorgan could earn on this option by exercising it and selling the stock was uncapped (i.e., unlimited). ${ }^{60}$ In addition, in connection with Bear's agreement to be acquired, JPMorgan agreed to guarantee certain of Bear's trading liabilities through a third-party guarantee agreement. This guarantee, however, expired upon the termination of the merger agreement. Nonetheless, the guarantee would still apply to any liabilities incurred by Bear before termination so long as the Bear board of directors had not previously recommended that its shareholders vote against the JPMorgan transaction. ${ }^{61}$ Finally, the merger agreement contained a force-the-vote provision under Delaware General Corporation Law $\S 146$ which required Bear to repeatedly hold its shareholder meeting for one year from the date

Cong. (2008) (statement of Robert K. Steel, Under Secretary for Domestic Finance), http://banking.senate.gov/public/index.cfm?FuseAction=Files.View\&FileStore_id=95e2fla e-1dc8-49ad-84c0-f8d9ald38bd8.

59. Kelly, supra note 55.

60. Bear Stearns Cos., Current Report (Form 8-K), exhibit 99.2 (Stock Option Agreement) (Mar. 20, 2008), http://www.sec.gov/Archives/edgar/data/777001/ 000091412108000252/be12335840-ex99_2.txt.

61. Bear Stearns Cos., Current Report (Form 8-K), exhibit 99.1 (Guaranty Agreement) (Mar. 20, 2008), http://www.sec.gov/Archives/edgar/data/777001/ 000091412108000252/be12335840-ex99_1.txt. 
of the agreement or until Bear's shareholders approved the merger agreement and the merger. ${ }^{62}$

The option and the force-the-vote terms in the Bear merger agreement were modeled upon more-traditional provisions of this type. However, both deal-protection devices differed from the standard provisions in fundamental ways. The option granted by Bear to JPMorgan was an uncapped one, providing for unlimited compensation to JPMorgan in the case of a competing, higher bid, a feature that the Delaware courts had ruled invalid in other circumstances in the 1994 case of Paramount Communications, Inc. v. QVC Network, Inc. ${ }^{63}$ Moreover, the provision providing for Bear to rehold its shareholder meeting for one year until the merger agreement was approved was a modification of a traditional forcethe-vote provision which only required that the company hold one vote. It too was of dubious legal validity under the Blasius standard and perhaps other Delaware standards of review-including as coercive or preclusive antitakeover devices invalid under the Unocal doctrine. ${ }^{64}$

These innovations were negotiated in the hurry of a forty-eight-hour period. JPMorgan would soon discover that these provisions did not work as the parties originally intended. In particular, the one-year revote provision provided Bear Stearns a one year "put," or option-to-sell, right to JPMorgan. During this time, the JPMorgan guarantee would be in place and Bear could operate safe in the assurance that its liabilities would be backed by the guarantee. ${ }^{65}$ JPMorgan realized after the announcement of this agreement and the hostile reaction of Bear's shareholders that the

62. See Bear Stearns Cos., Current Report (Form 8-K), exhibit 2.1 (Agreement and Plan of Merger by and Between Bear Stearns Cos. and IP Morgan Chase \& Co.) (Mar. 20, 2008), http://www.sec.gov/Archives/edgar/data/777001/000091412108000252/be12335840ex2_1.txt.

63. 637 A.2d 34, 51 (Del. 1993).

64. See Blasius Indus., Inc. v. Atlas Corp., 564 A.2d 651, 661 (Del. Ch. 1988); Unocal Corp. v. Mesa Petroleum Co., 493 A.2d 946, 955-57 (Del. 1985). Blasius and Unocal set the framework for courts to review certain actions taken by boards of directors in the context of a shareholder vote or defensive measure, respectively. Blasius requires a "compelling justification" for intentional interference with shareholders' voting franchise by a board of directors. Blasius, 564 A.2d at 660-62; see also MM Cos. v. Liquid Audio, Inc., 813 A.2d. 1118 (Del. 2003). Unocal, as subsequently applied by the Delaware courts, applies a three-pronged test to determine whether the board reasonably perceived a threat to the corporation and whether the defensive measure taken was either preclusive or coercive and reasonable in relation to the threat posed. Unocal, 493 A.2d at 955-57; see also Unitrin, Inc. v. Am. Gen. Corp., 651 A.2d 1361 (Del. 1995). See generally Marcel Kahan \& Edward Rock, How to Prevent Hard Cases from Making Bad Law: Bear Stearns, Delaware, and the Strategic Use of Comity, 58 EMORY L.J. 713 (2009) (elaborating on the Blasius and Unocal standards in the context of the Bear Stearns transactions).

65. See Posting of Steven M. Davidoff to N.Y. Times DealBook, http://dealbook.blogs.nytimes.com/2008/03/24/bears-big-guarantee/ (Mar. 24, 2008, 9:30 EST). 
interaction of these two provisions could allow Bear to stabilize during this time period and find a third-party buyer who could pay a higher price. ${ }^{66}$ And Bear realized this too. ${ }^{67}$ Moreover, parties were still refusing to trade with Bear because of the uncertainty surrounding this transaction.

On this basis, the parties entered into a renegotiation to reform these provisions and more tightly bind Bear to JPMorgan. ${ }^{68}$ In exchange for an increase in the consideration paid to $\$ 10$ per share in JPMorgan common stock and a guarantee which extended to additional Bear liabilities, JPMorgan's $19.9 \%$ option was eliminated. In exchange, JPMorgan was issued a $39.5 \%$ stake in Bear or 95 million newly issued common shares in exchange for 20,665,350 newly issued common shares in JPMorgan worth $\$ 950$ million on the date of announcement. ${ }^{69}$ In addition, JPMorgan immediately acquired another $9.93 \%$ of Bear's shares in the open market, giving JPMorgan an aggregate $49.43 \%$ ownership of Bear at the time of the establishment of the record date for voting on the Bear transaction. ${ }^{70}$ Finally, the guarantee was amended so that it terminated 120 days after the first "no" vote of Bear's shareholders on the merger agreement and the merger. ${ }^{71}$

The initial transaction had largely been within the confines of a traditionally structured strategic acquisition. However, the second deal pushed further afar from the traditional deal structure and was designed to increase the chance that JPMorgan's acquisition of Bear would occur. This was particularly true of Bear's issuance of $39.5 \%$ of its outstanding common stock, a truly novel provision which, together with JPMorgan's market purchases, stretched Delaware law to the breaking point. ${ }^{72}$

66. See Andrew Ross Sorkin, JPMorgan in Negotiations to Raise Bear Stearns Bid, N.Y. Times, Mar. 24, 2008, at A1; Kelly, supra note 55.

67. Kelly, supra note 55.

68. Sorkin, supra note 66.

69. Bear Stearns Cos., Current Report (Form 8-K), exhibit 2.2 (Share Exchange Agreement) (Mar. 24, 2008), http://www.sec.gov/Archives/ edgar/data/777001/000091412108000260/be12368022-ex2_2.txt. The JPMorgan shares were not registered and JPMorgan did not provide registration rights to Bear for these shares. This was presumably done so that the resale of these shares by Bear would be extremely difficult. Bear could not therefore sell them to independently increase its liquidity continuing its dependence upon JPMorgan. See Posting of Steven M. Davidoff to N.Y. Times DealBook, http://dealbook.blogs.nytimes.com/2008/03/24/jpmorgan-and-bearthrow-down-the-gauntlet/ (Mar. 24, 2008, 14:34 EST).

70. Bear Stearns Cos., Definitive Proxy Statement (Schedule 14A) (April 28, 2008), http://www.sec.gov/Archives/edgar/data/777001/000119312508092860/ddefml4a.htm.

71. Bear Stearns Cos., Current Report (Form 8-K), exhibit 99.1 (Amended and Restated Guaranty Agreement) (Mar. 24, 2008), http://www.sec.gov/Archives/ edgar/data/777001/000091412108000260/be12368022-ex99_1.txt.

72. Bear's $39.5 \%$ share issuance was no doubt structured separately from the open market share purchase to comply with the Delaware ruling in Omnicare, Inc. v. NCS Healthcare, Inc., 818 A.2d. 914, 938 (Del. 2003). By separating these purchases in distinct 
JPMorgan, advised by its attorneys, appeared willing to push the bounds of Delaware law, but in structuring the revised transaction in this manner, JPMorgan no doubt felt safe in an assurance that a court would be reluctant to challenge a federal-government-backed deal. Here, the federal government had endorsed the second deal, albeit insisting that its guarantee be revised to provide that JPMorgan bear the first billion dollars of losses under it. ${ }^{73}$ The Federal Reserve was demonstrating its willingness for an ordered solution, but Treasury officials also reportedly expressed private displeasure at Bear stockholders receiving this increased consideration.

JPMorgan and its lawyers proved right in their judgments about any court challenge. On April 9, 2008, Vice Chancellor Roger Parsons abstained from ruling in the shareholder litigation brought by shareholders in the Delaware Chancery Court challenging the transaction. ${ }^{74}$ He stated, "I find the circumstances of this case to be sui generis. What is paramount is that this Court not contribute to a situation that might cause harm to a number of affected constituencies, including U.S. taxpayers and citizens, by creating the risk of greater uncertainty." 75

Professors Kahan and Rock have described this as a strategic use of comity, and they appear right. ${ }^{76}$ Delaware did not want to be seen as challenging the federal government. The plaintiffs in the New York case initially pursued a preliminary injunction hearing, but they too soon realized that a New York court would similarly be reluctant to challenge the federal government. On May 7, 2008, the plaintiffs dropped their motion for an injunction, instead electing to pursue monetary damages. ${ }^{77}$

JPMorgan's acquisition of Bear closed on May $30,2008 .^{78}$

transactions, JPMorgan could attempt to defend the share issuance if the open market purchases were found by a Delaware court to violate Omnicare's prohibitions on completely locked-up acquisition transactions. See Posting of Steven M. Davidoff to N.Y. Times DealBook, http://dealbook.blogs.nytimes.com/2008/03/24/is-jpmorgan-getting-too-clever/ (Mar. 24, 2008, 12:06 EST) (stating that JPMorgan's share acquisitions were likely structured to preserve a litigation position that these were two purchases that should be viewed separately).

73. Press Release, Fed. Reserve Bank of N.Y., supra note 48.

74. See In re Bear Stearns Cos. Shareholder Litigation, C.A. NO. 3643-VCP, 2008 WL 959992, at*8 (Del. Ch. Apr. 9, 2008).

75. Id. at *6.

76. See Kahan \& Rock, supra note 64; see also Faith Stevelman, Regulatory Competition, Choice of Forum, and Delaware's Stake in Corporate Law, 34 DEL. J. CoRP. L. 57 (2009).

77. Posting of Steven M. Davidoff to N.Y. Times DealBook, http://dealbook.blogs.nytimes.com/2008/05/09/euthanizing-bear/ (May 9, 2008, 11:28 EST). The plaintiffs' claims were subsequently dismissed by the New York court on December 4, 2008. In re Bear Stearns Litigation, 870 N.Y.S.2d 709 (Sup. Ct. 2008), available at 2008 WL 5220514.

78. Bear Stearns Cos., Current Report, (Form 8-K) (June 2, 2008), http://www.sec.gov/ Archives/edgar/data/777001/000091412108000468/0000914121-08-000468-index.htm. 


\section{The Initial Stage: The Government as Dealmaker}

The period following the fall of Bear Stearns and the crisis in subprime mortgages prompted four responses by the government over the next six months. First, on the day that Bear agreed to be acquired by JPMorgan, the Federal Reserve opened its discount window beyond the banks that it oversees, specifically to the seventeen-odd institutions listed by the New York Federal Reserve as "primary dealers" in government securities that reported their statistics to the Federal Reserve. ${ }^{79}$ The availability of this inexpensive money was to be secured by a wide range of investment-grade securities. ${ }^{80}$ Once again, $\S 13$ of the Federal Reserve Act was the basis for the novel expansion of the window. ${ }^{81}$

Second, the government used the crisis to push for some long-cherished reform of the financial regulatory system. On March 31, 2008, Secretary Paulson released a report recommending administrative and legislative changes to government regulation of finance. The recommendations-the so-called Paulson Blueprint-plumped for enhanced powers for bank regulation, to be placed into the hands of the Federal Reserve as well as Treasury, and for the regulatory supervision apparatus of the government to be consolidated by, among other things, merging the CFTC with the SEC. ${ }^{82}$ The report did not result in any immediate congressional action, and indeed was derided by many legislators as having no chance of passage, not least because it was propounded by an unpopular Administration during an election year.

Third, the Federal Reserve, after its novel involvement in the Bear Stearns takeover, reverted to its more typical role of setting macro-level monetary policy. In the period from March 18, 2008, to October 8, 2008, the Federal Reserve continued to cut the target rate for federal funds from $2.25 \%$ to $1.5 \%{ }^{83}$ and the discount rate from $2.5 \%$ to $1.75 \%{ }^{84}$

Fourth, on July 24, 2008, the government passed the Housing and Economic Recovery Act of 2008 (HERA), ${ }^{85}$ an attempt to address the

79. Federal Reserve Bank of New York, Primary Dealer Credit Facility: Program Terms and Conditions, http://www.newyorkfed.org/markets/pdcf_terms_080316.html (last visited Apr. 16, 2009).

80. Id.

81. See 12 C.F.R. $\S 201.4(\mathrm{~d})$ (2009).

82. See U.S. DEP'T OF TREASURY, BLUEPRINT FOR A MOdERnized FinANCIAL REGULATORY STRUCTURE (2008), http://www.treas.gov/press/releases/reports/Blueprint.pdf.

83. FED. RESERVE BD., supra note 23.

84. See FED. RESERVE Discount Window, Historical Discount Rates, http://www.frbdiscountwindow.org/historicalrates.cfm?hdrID=20\&dtlID (follow "primary and secondary credit" link).

85. Housing and Economic Recovery Act of 2008, Pub. L. No. 110-289, 122 Stat. 2654 (2008) (to be codified at 42 U.S.C. $\S 4511$ ). 
housing crisis. HERA provided, in theory, $\$ 300$ billion in aid to subprime housing buyers (if they could qualify for it) and also set the GSEs as principal actors in engineering a housing recovery. ${ }^{86}$ The bill increased the regulatory oversight of the two GSEs and expanded the conservatorship powers of the federal government over the entities. ${ }^{87}$ At the time of the passage of this Act, Secretary Paulson, commenting on the conservatorship powers the HERA provided the new Federal Housing Administration (FHA), stated that "[i]f you've got a bazooka, and people know you have it, then you may not have to take it out." 88

These four actions were each, in their own way, dramatic, but none of them were designed to comprehensively resolve the crisis, which had spread from housing to finance and existed in the present, while portending an increasingly threatening future. The hope apparently was that the broadening of the discount window would be enough to protect the financial system. The homeowner aid, though somewhat small solace, was aimed at that section of the economy, and the regulatory reform proposals, which were anything but small gestures, were quickly deemed to be a project for the future. ${ }^{89}$

The government apparently hoped that the markets would take the lead in sorting themselves out. However, for some companies, particularly Fannie Mae and Freddie Mac, the private markets no longer appeared to be a good alternative. In July and August 2008 storm clouds began to gather over both companies. The government urged the institutions to recapitalize, but their stockholders resisted the dilution, and investors, wary perhaps of an equity-destroying Bear Stearns-like bailout, stayed away. ${ }^{90}$

On July 11, 2008, the Office of Thrift Supervision (OTS) ominously closed the IndyMac Bank and placed it into conservatorship with the Federal Deposit Insurance Corporation (FDIC). ${ }^{91}$ This was the secondlargest bank failure in the United States. Even after the bank was seized, people lined up in the thousands to withdraw their money despite the existence of federal insurance for their deposits, which was particularly troubling for the government. ${ }^{92}$

86. Id. $\S 1311$.

87. Id.

88. Stephen Labaton \& David M. Herszenhorn, A Rescue for Fannie and Freddie Kindles Opposition and Political Duels, N.Y. TIMES, July 16, 2008, at C1.

89. See Damian Paletta, Regulators Take Steps to Aid Bank Liquidity, WALl ST. J., July 16 , 2008, at A2 (discussing the FDIC's new policies aimed at increasing financing availability for mortgage origination and securitization).

90. James R. Hagerty \& Serena $\mathrm{Ng}$, Banks Hit as Fannie, Freddie Get Downgrade, WaLl ST. J., Aug. 23-24, 2008, at A1.

91. Louise Story, Regulators Seize IndyMac After a Run on the Bank, N.Y. TIMES, July 12,2008 , at C5.

92. See E. Scott Reckard \& Andrea Chang, Banks Hit by Fallout from the Crisis at 
In late August, the ratings agencies downgraded the preferred stock ratings of Fannie and Freddie from $A$ minus to AA minus, in the case of Standard \& Poor's, and from A1 to Baa3, in the case of Moody's. In light of this, the need for each GSE to raise capital was further heightened but also made more difficult. ${ }^{93}$ The market pressure on Fannie's and Freddie's stocks due to solvency fears created yet another detrimental self-reinforcing feedback loop ensuring that these fears would come to pass. This problem appeared particularly exacerbated in the case of Fannie and Freddie by the possibility of nationalization by the federal government, a factor that further shied off possible investors. Paulson's big bazooka unfortunately appeared to serve the opposite from its intended purpose.

\section{The Nationalization of Fannie Mae and Freddie Mac}

After losing the market's confidence, Fannie and Freddie lost the government's confidence the weekend of September 5, 2008. First, government auditors discovered that the accounting records of Fannie and Freddie significantly overstated their capital. ${ }^{94}$ According to these accounting reevaluations, the GSEs, thinly capitalized in the best of times, were technically insolvent. Second, the government concluded that whatever efforts the GSEs were making to recapitalize were failing. Treasury resolved to seize the enterprises on September 7, pursuant to its authority under HERA-a rare instance during this period where the Federal Reserve's $\S 13$ powers were not involved. ${ }^{95}$

That statute provided that the FHA, the primary regulator of the GSEs,

IndyMac, L.A. TIMES, July 15, 2008, at A1. Notably, at the time the Office of Thrift Supervision (OTS) attacked Senator Charles Schumer for causing the collapse of the bank. The OTS stated in its press release announcing the closing that

[t]he immediate cause of the closing was a deposit run that began and continued after the public release of a June 26 letter to the OTS and the FDIC from Senator Charles Schumer of New York. The letter expressed concerns about IndyMac's viability. In the following eleven business days, depositors withdrew more than $\$ 1.3$ billion from their accounts.

See Press Release, Office of Thrift Supervision, OTS Closes IndyMac Bank and Transfers Operations to FDIC (July 1 l, 2008), http://www.ots.treas.gov/index.cfm?p=PressReleases\& ContentRecord_id=37f10b00-1 e0b-8562-ebdd-d5d38f67934c\&Content Type_id=4c12f337b5b6-4c87-b45c-838958422bf3\&MonthDisplay=7\& YearDisplay=2008.

93. See Hagerty \& $\mathrm{Ng}$, supra note 90 (describing the effects of such downgrades on banks and investors and noting the increased fears among them that the government might move to take full control of the GSEs).

94. See Gretchen Morgenson \& Charles Duhigg, Mortgage Giant Overstated Size of Capital Base, N.Y. TIMES, Sept. 7, 2008, at Al.

95. The ensuing conservatorship decision was technically invoked by the Federal Housing Authority (FHA), an independent government agency, but the FHA appeared to follow the decisions of the Treasury Department on this matter-at least, the negotiations happened at Treasury, and the conservatorship was announced by Paulson See Charles Duhigg, As Crisis Grew, a Few Options Shrank to One, N.Y. TimES, Sept. 8, 2008, at A1. 
"is authorized ... to appoint conservators for the enterprises." "96 Moreover, HERA had provided the Treasury Secretary with an equally broad grant of authority to recapitalize the GSEs. Section 1117 of HERA stated, "the Secretary of the Treasury is authorized to purchase any obligations and other securities issued by the corporation ... on such terms and conditions as the Secretary may determine and in such amounts as the Secretary may determine." 97

The CEO of each GSE was fired and replaced. In addition, the FHA later cut the exit package of the Fannie CEO as much as $\$ 8$ million and the Freddie CEO from $\$ 15$ million $^{98}$ under the authority of $\S 1318$ of the Federal Housing Enterprises Financial Safety and Soundness Act of 1992 as amended by HERA. ${ }^{99}$ This last act would be the sole example of the government acting to claw back executive pay in connection with a bailout. In order to increase each GSE's capital, Treasury also entered into senior preferred share purchase agreements with Fannie Mae and Freddie Mac for each to issue up to $\$ 100$ billion of senior preferred stock to the Treasury Department. ${ }^{100}$

The GSEs initially issued only $\$ 1$ billion of preferred stock but each was permitted to draw greater amounts up to this $\$ 100$ billion limit as needed up to the amount, if any, by which its total liabilities exceeded total assets. ${ }^{101}$ The issued preferred shares were ranked senior to Fannie's and Freddie's existing preferred shares and paid Treasury a $10 \%$ yield if paid in cash and $12 \%$ if paid in kind. ${ }^{102}$ This yield was significantly below the approximate $15 \%$ yield on the GSEs' other outstanding preferred. ${ }^{103}$ The

96. 12 U.S.C $\$ 4513(b)$ (2006).

97. Housing and Economic Recovery Act of 2008, Pub. L. No. 110-289, § 1117, 122 Stat. 2654, 2684 (2008) (to be codified at 12 U.S.C. $\$ 1719$ ).

98. James R. Hagerty, Regulator Plans to Bar Big Severance, WALL ST. J., Sept. 15, 2008 , at Al.

99. 12 U.S.C. $\S 4518$ (2006), amended by Pub. L. No. 110-289, § 1114, 122 Stat. 2654, 2679-81 (2008).

100. See Fed. Nat'l Mortgage Ass'n, Current Report (Form 8-K), at 4 (Sept. 11, 2008) [hereinafter FNMA Form 8-K], http://www.sec.gov/Archives/edgar/data/310522/ 000095013308003096/w67133e8vk.htm; Fed. Home Loan Mortgage Corp., Current Report (Form 8-K) (Sept. 11, 2008) [hereinafter FHLM Form 8-K], http://www.sec.gov/ Archives/edgar/data/1026214/000102621408000030/f67154e8vk.htm. These preferred stock commitments would later be increased to $\$ 200$ billion each. See Press Release, U.S. Dep't of the Treasury, Statement by Secretary Tim Geithner on Treasury's Commitment to Fannie Mae and Freddie Mac (Feb. 18, 2009), http://www.treas.gov/press/releases/tg32.html.

101. Office of Pub. Affairs, U.S. Dep't of the Treasury, Fact Sheet: Treasury SENIOR PREFERRED STOCK PURCHASE AGREEMENT (2008), http://www.treas.gov/press/releases/reports/pspa_factsheet_090708\%20hpl 128.pdf.

102. Id.

103. Press Release, Fannie Mae, Fannie Mae Announces Third Quarter Common and

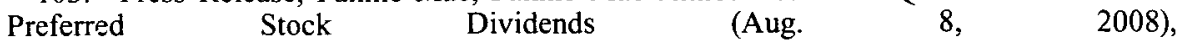
http://www.fanniemae.com/newsreleases/2008/4445.jhtml;jsessionid=K1 SEMXFZDKW2V 
terms of the preferred prevented each GSE from paying any dividend on the GSE's equity securities while any part of the government's preferred interest remained outstanding. ${ }^{104}$

Treasury also received a warrant to purchase $79.9 \%$ of the outstanding common stock of each of Fannie and Freddie. The warrant was exercisable for a twenty-year period and had a nominal exercise price of $\$ 0.00001$ per share. ${ }^{105}$ Through this mechanism, the government effected a transaction to significantly, but not completely, dilute the holders of these securities and significantly reduce their value. But the government did not place its ownership interest higher into the capital structures of each GSE in order to penalize or otherwise wipe out the secured or subordinated debt of these entities.

This was likely done for both political and economic reasons-again the government's actions were constrained by the outer boundaries of the law. The secured debt was issued by Fannie and Freddie to finance mortgage lending and had historically been viewed as having an implicit (now effectively explicit) government guarantee. The amount outstanding was over $\$ 5.14$ trillion in mortgage-backed securities and guarantees, and Treasury could not eliminate or otherwise impair this debt without risking significant, if not catastrophic, disruption to the mortgage market. ${ }^{106}$ The subordinated debt was generally perceived by the market as riskier and was not viewed as having a government guarantee. ${ }^{107}$ Fannie and Freddie utilized this debt to finance their riskier, nonconforming loans and for trading capital. ${ }^{108}$ However, a substantial portion of the subordinated debt, like much of the secured debt, was held by foreign financial institutions and sovereigns. It was privately viewed that if this debt was impaired, it would

J2FQSISFGI?p=Media\&s=News+Releases; Press Release, Freddie Mac, Freddie Mac Summary of Dividends (2008), http://www.freddiemac.com/investors/pdffiles/div0908.pdf.

104. OFFICE OF PUB. AfFAirs, supra note 101.

105. See FNMA Form $8-\mathrm{K}$, supra note 100 , at $2,9$.

106. Fannie's total mortgage portfolio in the consolidated balance sheets as of December 31,2007 , was $\$ 2,832,793$ million with an additional $\$ 206.5$ billion for other guaranties not recorded in the consolidated balance sheets. FED. NAT'L MORTGAGE ASS'N, ANNUAL REPORT (Form 10-K) (Feb. 27, 2008) [hereinafter FNMA Form 10-K], http://www.sec.gov/Archives/edgar/data/310522/000095013308000795/w48295el0vk.htm. Freddie's total mortgage portfolio as for December 31, 2007, was $\$ 2,102,676$ million. FREDDIE MAC, 2007 ANNUAL REPORT [hereinafter FHLMA Annual Report], http://www.freddiemac.com/investors/ar/pdf/2007annualrpt.pdf. The combined mortgage portfolios and guarantees of both GSEs amounted to $\$ 5,141,969$ million. See James R. Hagerty et al., U.S. Seizes Mortgage Giants: Government Ousts CEOs of Fannie, Freddie; Promises Up to $\$ 200$ Billion in Capital, WALL ST. J., Sept. 8, 2008, at Al.

107. See Standard \& PoOr's, Research Update: Fannie MaE and Freddie MaC Ratings Placed on Credit Watch Negative; Senior Debt Rating Affirmed 2 (2008).

108. See FNMA Form 10-K, supra note 106, at 116; FHLMA Annual Report, supra note 106 , at 5 . 
drive away foreign lenders from U.S. debt at a time when the United States required this money to service its federal obligations. ${ }^{109}$ Thus, the government limited its actions to impairing the value of the GSEs' preferred and common stock. Here, the government particularly impacted the many depositary institutions that were permitted to invest in the GSEs' preferred stock and had done so in search of a higher return.

Moreover, the government did not completely wipe out the preferred and common shareholders of the GSEs. Rather, the government limited its interest to the $79.9 \%$ figure. The exact reasons for this limitation have yet to be disclosed, but it does not appear that this issuance was structured to maintain value for the security holders. Rather, it was likely done for one or more of the following reasons: (1) to support a position that the GSEs did not have to be consolidated onto the books of the federal government for accounting purposes (something the Congressional Budget Office disputed); (2) to build a case that each GSE was not now a governmentcontrolled entity so that the government's unique accounting rules did not have to be adopted by these entities; (3) to ensure that these GSEs could still deduct interest paid on their loans from the government, something they would be unable to do under $\S 163$ of the Internal Revenue Code if they were deemed "controlled" by the government; ${ }^{10}$ and (4) to ensure for Employee Retirement Income Security Act (ERISA) purposes that the GSEs were not deemed "controlled" by the government, making the government joint and severally liable for these entities' ERISA plan liabilities. ${ }^{111}$

A former Treasury official would later assert that this was indeed done for accounting purposes in order to keep Fannie Mae's and Freddie Mac's liabilities off the government's balance sheet. ${ }^{112}$ But for whatever reason, the government felt that it could not completely eliminate these security holders' interests. The government's willingness, as with Bear, to seemingly act within the law had allowed the Fannie and Freddie preferred and common shareholders to retain a meaningful interest in the companies. Moreover, to the extent the government was fighting moral hazard, it would have presumably have wanted to also impair Fannie's \$11.1

109. David M. Dickson \& David R. Sands, Overseas Debt Drives Bailout of Fannie, Freddie, WASH. TIMES, Sept. 9, 2008, at A1.

110. This reason was likely not applicable here as the GSEs lacked profits in the foreseeable future.

111. See Employee Retirement Income Security Act of 1974, 29 U.S.C. $\S 1002(14)(E)$ (2006).

112. See Swagel, supra note 6 ("The 79.9 percent ownership was chosen in light of accounting rules that would have brought GSE assets and liabilities onto the government balance sheet at 80 percent ownership."). 
billion ${ }^{113}$ and Freddie's $\$ 4.5$ billion $^{114}$ outstanding subordinated debt. This did not happen. Instead, the government was acting as a dealmaker structuring a bailout using the law, but also acting within and to the limits of its political interests. This led Treasury and the Federal Reserve to impair the preferred and common shareholders and the FHA to limit the severance packages of these CEOs, but it did not go so far as allowing the government to act purely in pursuit of its stated purposes. Even assuming that it had any bearing in a financial action of this enormity, moral hazard in this context thus seemed to, at best, be a shaky principle to rely upon to justify the government's structuring actions.

In connection with the conservatorship of Fannie and Freddie, the federal government had now become the owner or guarantor of approximately $42 \%$ of American mortgages, and the extent of the guarantees was only growing in size and scope. ${ }^{15}$ Secretary Paulson announced that these entities' retained mortgage and mortgage-backed securities portfolio would be shrunk to a smaller size of approximately $\$ 850$ billion in assets by December 31,2009 , and would continue to decline by $10 \%$ per year until each reached an asset portfolio size of $\$ 250$ billion. ${ }^{116}$ However, this would only occur in later years. Instead, Secretary Paulson announced that the government intended to grow these institutions over the next fifteen months in order to provide assistance to the housing market. ${ }^{117}$

In addition, the Federal Reserve also announced that it would accept a wider array of collateral at the discount window from investment banks, including equity securities. ${ }^{118}$ The legal authority for this was, once again, the flexible $\S 13$ of the Federal Reserve Act, which makes the discount window widely available. Haphazardly, the Treasury and Federal Reserve were beginning to guarantee much of the U.S. financial system.

113. Fed. Nat'l Mortgage Ass'n Quarterly Report (Form 10-Q), at 82 (Aug. 8, 2008), http://www.fanniemae.com/ir/pdf/earnings/2008/q22008.pdf.

114. See Fed. Home Loan Mortgage Corp., Quarterly Report (Form 10-Q) (Aug. 6, 2008),

http://sec.gov/Archives/edgar/data/1026214/000102621408000026/f58905el0vq.htm.

115. The figure is as of September 20, 2008. See Fed. Nat'l Mortgage Ass'n, Quarterly Report (Form 10-Q), at 9 (Nov. 10, 2008), http://sec.gov/Archives/edgar/data/310522/000095013308003686/w71392el0vq.htm; Fed. Home Loan Mortgage Corp., Quarterly Report (Form 10-Q) (Nov. 14, 2008), http://sec.gov/ Archives/edgar/data/1026214/000102621408000043/f65508e10vq.htm\#113.Sep.

116. See OFFICE OF PUB. AfFAIRS, supra note 101.

117. See Press Release, U.S. Dep't of the Treasury, Statement by Secretary Henry M. Paulson Jr. on Treasury and Federal Housing Finance Agency Action to Protect Financial Markets and Taxpayers (Sept. 7, 2008), http://www.ustreas.gov/press/releases/hp1 129.htm.

118. Press Release, Bd. of Governors of the Fed. Reserve Sys. (Sept. 14, 2008), http://www.federalreserve.gov/newsevents/press/monetary/20080914a.htm. 


\section{The Week that Changed Everything}

In the wake of the partial nationalization of Fannie and Freddie, the already-troubled credit markets began to completely freeze up. ${ }^{119}$ But the government still did not directly act. Indeed, when the Federal Reserve met on September 16, it did not again lower interest rates and instead focused on the problem of commodity inflation. ${ }^{120}$ Still, it was apparent that the credit market remained disrupted. This was a very different animal than an equity decline, which had been typical of financial crises in the past century. Unlike equity crises, this was something that was harder for the public to see.

\section{a. The Bankruptcy of Lehman Brothers and the Sale of Merrill Lynch}

During the weekend of September 13, 2008, Lehman suffered from the same self-fulfilling feedback loops as Bear. On September 10, 2008, Lehman had pre-announced quarterly earnings: a loss of $\$ 3.9$ billion for that quarter and gross asset write-downs of $\$ 7.8$ billion. ${ }^{121}$ Lehman also announced on that day plans to hive off its troubled commercial-real-estaterelated and other assets into a separate "bad" bank. ${ }^{122}$ The plan had been criticized as insufficient by many analysts. ${ }^{123}$ Rumors began to circulate of Lehman's inability to survive. ${ }^{124}$ These rumors quickly created their own feedback loop as customers began to pull assets from Lehman and demand collateral on counterparty trades as they became concerned for Lehman's

119. Carrick Mollenkamp et al., Lending Among Banks Freezes, WALL ST. J., Sept. 17, 2008, at Al.

120. See Press Release, Bd. of Governors of the Fed. Reserve Sys. (Sept. 16, 2008), http://www.federalreserve.gov/newsevents/press/monetary/20080916a.htm (noting that "the inflation outlook remains highly uncertain"). This was not an irrational move by the Federal Reserve. The economy and exports were still growing while commodity inflation was reaching historical levels. Moreover, there was a common wisdom theory being circulated that the current credit crisis had been brought on by an unduly low level of interest rates set by the Federal Reserve in the period from 2001 to 2005. See, e.g., Allan Sloan, How Keeping Short Rates Low Created a Fiasco, WASH. Post, Sept. 17, 2008 , at D7.

121. Lehman Bros. Holdings, Inc., Current Report (Form 8-K), exhibit 99.1 (Press Release, Lehman Brothers Announces Preliminary Third Quarter Results and Strategic $\begin{array}{lllll}\text { Restructuring), at } 5 \text { (Sept. } & \text { 10, }\end{array}$ http://sec.gov/Archives/edgar/data/806085/0001 10465908057829/a08-22764_2ex99d1.htm.

122. Id. at 3. Lehman intended to spin off $\$ 25$ billion to $\$ 30$ billion of its commercial real estate portfolio into a separate publicly traded company, Real Estate Investments Global, in the first quarter of 2009. Id.

123. Randall Smith, Lehman's Revamp Plan Draws Doubters: Analysts Wonder If Fixes Can Occur in Time to Be of Help, WALL ST. J., Sept. 11, 2008, at C1.

124. See Joe Bel Bruno, Lehman Plunges on Concerns About Capital Levels, ASSOCIATED PRESS, Sept. 9, 2008 ("The steep decline in Lehman's shares began shortly after Dow Jones Newswires reported that the head of South Korea's financial regulator said talks about a possible investment had ended."). 
survival. By the weekend of September 13, Lehman's liquidity position had significantly deteriorated, to approximately $\$ 1$ billion, and the company was facing a loan call by JPMorgan. ${ }^{125}$ Lehman was the next financial institution faced with insolvency if it could not find a buyer or obtain government backing. Initially, Bank of America and Barclays were interested acquirers. ${ }^{126}$

But Merrill Lynch \& Co. had its own problems emerging at this time; after Lehman, Merrill was perceived as the next at risk of the five investment banks. Merrill's CEO Jonathan Thain would conclude that if Lehman did not survive, his bank would now be viewed as the weakest of the investment banks and subject to the same viral self-fulfilling feedback loops. ${ }^{127}$ The perception of the viability of the investment-bank model was now in question. In light of the market turmoil and higher leverage ratios of these investment banks compared to more-regulated bank holding companies, market participants were fearful of doing business and investing in these institutions. Market investors, aware of this wariness, began selling their stock in the investment banks, once again making it harder for them to raise capital and assuage investors, leading to more concern about the survival of these institutions-the feedback loop was whirring.

Fearful of Merrill's survival and being stuck in such a loop, Thain contacted Bank of America about an acquisition, and that weekend Merrill agreed to be acquired in an approximately $\$ 50$ billion transaction by Bank of America. ${ }^{128}$ This left only Barclays as a willing acquirer of Lehman. Likely due to political reality, personal preference, and legal limitations on the government's power, Paulson insisted that the private market find a solution to Lehman Brothers. However, Barclays was thrown out of the race when its own British regulator, the Financial Services Authority, refused to approve an acquisition. ${ }^{129}$ Perhaps because they felt that the government would actually act and they could still free ride on such

125. Carrick Mollenkamp et al., The Two Faces of Lehman's Fall: Private Talks of Raising Capital Belied Firm's Public Optimism, WaLl ST. J., Oct. 6, 2008, at A1. On September 11, JPMorgan demanded from Lehman $\$ 5$ billion in additional collateral in easyto-sell securities to cover lending positions that JPMorgan's clients had with Lehman. Id.

126. See Hilsenrath et al., supra note 7.

127. See Merrill Lynch \& Co., Proxy Statement (Schedule 14A), at 49-52 (Nov. 3, 2008), http://www.sec.gov/Archives/edgar/data/65100/000095012308014246/ g15211mldefm14a.htm; see also Jonathan Keehner \& Bradley Keoun, Bank of America Said to Reach $\$ 44$ Billion Deal to Buy Merrill, BLoOMBERG.Com, Sept. 14, 2008, http://www.bloomberg.com/apps/news?pid=20601110\&sid=alGol3fTq1Us (quoting an analyst stating that "[i]f Lehman fails, the next bank to be attacked would be Merrill. They are attempting to forestall that attack by linking with Bank of America.").

128. See Cohan, supra note 45 , at 435.

129. Id. at 439 . 
government conduct, the major financial institutions also refused to assist Lehman directly and instead put in a $\$ 70$ billion facility to backstop trading when Lehman filed for bankruptcy. ${ }^{130}$ On Monday, September 15, 2008, Lehman's holding company filed for Chapter 11. ${ }^{131}$ Notably, most of Lehman's subsidiaries did not file for bankruptcy, and on that Tuesday, Lehman agreed to sell its U.S. broker deal operation minus certain troubled commercial-real-estate-related assets to Barclays for a fire-sale price of $\$ 250$ million. $^{132}$

Many observers would accuse the government of making a mistake in failing to bail out Lehman, leaving its bondholders without recourse, the credit insurance that it had underwritten meaningless, and its significant issued commercial paper worthless. The finance minister of France criticized the government for letting such an important global financial player default on its obligations. ${ }^{133}$ Regardless of whether Lehman should have been allowed to fail, it is still unclear whether the government realized the extent of Lehman's obligations. On the other hand, the drastic market reactions that flowed from Lehman's failure ultimately drove the government to adopt a more comprehensive approach to the crisis.

But that approach had to wait. We interpret part of what drove the decision to let Lehman fail to an inclination by Paulson, who, as dealmakers sometimes do; wanted to make a statement about his willingness to bail out all financial institutions. Secretary Paulson would later publicly state that the reason he did not bail out Lehman was because "[w]e didn't have the powers," since Lehman lacked enough assets to provide sufficient collateral for a Federal Reserve loan. ${ }^{134}$ The government was clearly hamstrung here by the failure to have the power to simply seize Lehman. However, given that the Federal Reserve had previously interpreted (and would later interpret) its statutory authority to have broad reach to make loans in the context of the Bear Stearns matter, we believe this explanation is not credible. The government may not have been able to seize Lehman but the Federal Reserve could loan it money. Instead, it appears that Paulson was restricted from acting politically and wanted to

130. See Carrick Mollenkamp et al., Crisis on Wall Street as Lehman Totters, Merrill Is Sold, AIG Seeks to Raise Cash: Fed Will Expand Its Lending Arsenal in a Bid to Calm Markets; Moves Cap a Momentous Weekend for American Finance, WALl ST. J., Sept. 15, 2008, at A1.

131. Lehman Brothers Files for Chapter 11 Bankruptcy Protection, Associated PrESs, Sept. 15, 2008; Ben White \& Michael M. Grynbaum, The Street After Lehman Brothers, N.Y. Times, Sept. 16, 2008, at C1.

132. Jeffrey McCracken et al., Lehman in New Talks to Sell Assets to Barclays, WALL ST. J., Sept. 16, 2008, at Cl.

133. See Nocera \& Andrews, supra note 1.

134. Id. 
make a statement, as dealmakers do, about his willingness to bail out all financial institutions.

In the wake of the Lehman bankruptcy and Merrill's agreement to be acquired by Bank of America, the investment-banking model was shaky at best. On September 21, the final two independent investment banks regulated by the SEC, Goldman Sachs \& Co. and Morgan Stanley, Inc., left the agency's regulation to become bank holding companies, overseen by the Federal Reserve-and potentially protected by that apparently more capable agency. ${ }^{135}$ These two investment banks were pursuing a path toward stability by acquiring bank deposits-an ironic event as bank deposits were also short-term financing. Nonetheless, the market perception was that this model was more reliable than one which relied upon short-term prime brokerage deposits and repo lending for liquidity. The SEC's program overseeing investment banks like Bear Stearns and Lehman was quietly shuttered, meaning that any pretence that the SEC could make at performing banking-style supervision of the capitalization of investment banks ended. ${ }^{136}$ As the SEC chair would testify before Congress, somewhat charitably,

[The supervisory] program was fundamentally flawed from the beginning, because investment banks could opt in or out of supervision voluntarily. The fact that investment bank holding companies could withdraw from this voluntary supervision at their discretion diminished the perceived mandate of the CSE program, and weakened its effectiveness. ${ }^{137}$

\section{b. The Nationalization of AIG}

As Lehman died and Merrill disappeared, another famous financial name also teetered on the edge of insolvency. American International Group (AIG), a global financial conglomerate with the largest insurance business in the United States, had suffered approximately $\$ 21.7$ billion in losses out of its London subsidiary, which had been writing insurance and credit default swaps on mortgage-related assets. ${ }^{138}$ AIG looked more stable than the investment banks. ${ }^{139}$ AIG was principally an insurance company-the

135. See Posting of Michael J. de la Merced et al. to N.Y. Times DealBook, http://dealbook.blogs.nytimes.com/2008/09/21/goldman-morgan-to-become-bank-holdingcompanies/ (Sept. 21, 2008, 21:35 EST).

136. Press Release, SEC, Chairman Cox Announces End of Consolidated Supervised Entities Program (Sept. 26, 2008), http://www.sec.gov/news/press/2008/2008-230.htm.

137. Id.

138. As of September 30, 2008, the net unrealized market valuation loss of AIG's London Subsidiary, AIG Financial Products Corp., from super senior credit default swap portfolio amounted to \$21.726 billion. Am. Int'l Group, Inc., Quarterly Report (Form 10$\mathrm{Q}$ ), at 65 (Nov. 10, 2008) [hereinafter AIG Third Quarter Form 10-Q], http://www.sec.gov/Archives/edgar/data/5272/000095012308014821/y72212elovq.htm.

139. See Monica Langley et al., Bad Bets and Cash Crunch Pushed Ailing AlG to Brink, 
conventional wisdom was that any loss of confidence would only affect it slowly rather than in the overnight manner Bear and Lehman were struck. Nonetheless, AIG became caught in a different species of feedback loop, one driven by ratings cuts and mark-to-market accounting rules.

The decline in AIG stock, due to its losses and its inability to effectively raise capital due to these stock declines, had led the rating agencies to cut AIG from its AAA rating to A minus. ${ }^{140}$ Under the $\$ 441$ billion in derivative contracts AIG was a party to, it was consequently required to put up $\$ 14.5$ billion in collateral. ${ }^{141}$ AIG had never anticipated that it would be downgraded, but the collateral requirement in the midst of a credit crisis rendered the company technically insolvent and showed the fallacy of AIG's assumption. Moreover, in connection with this collateral requirement, AIG's accountants reviewed its asset values and AIG was forced to record mark-to-market losses of approximately $\$ 60$ billion. ${ }^{142}$ On Monday, September 15,2008, it was technically insolvent when the New York State Insurance Commissioner permitted AIG to borrow \$20 billion from AIG's own regulated insurance reserve funds. ${ }^{143}$

The federal government initially refused to provide financial assistance to AIG. But the Lehman treatment was short-lived. AIG held over one trillion dollars in assets and had 971 billion dollars in liabilities, ${ }^{144}$ and if it defaulted on its obligations, there was every prospect of a sequence of many cross-defaults, which in turn would have forced not just losses but a significant number of corporations to refinance their debt in a credit market that was incapable of doing so. The Federal Reserve thus decided on September 16 to provide financial assistance to AIG.

Once again, though, the government would be constricted by the limits of the law in structuring its rescue. And once again, the government stuck to its developing game plan for dealmaking, driving a hard bargain in reliance on previous precedent and relying on $\S 13$ of the Federal Reserve Act for authority. On September 16, AIG disclosed that

[i]n connection with the revolving credit facility, AIG issued a warrant to the Board of Governors of the Federal Reserve ... that permits the Federal

\footnotetext{
WALL ST. J., Sept. 18, 2008, at A1.

140. Hugh Son, AIG Rating Cuts Threaten Funding Quest, Shares Plunge, $\begin{array}{lll}\text { BLOOMBERG.COM, } & \text { Sept. } & \text { 16, } \\ \text { http://www.bloomberg.com/apps/news?pid=20601087\&sid=amuMN6feT0kE\&refer=home. }\end{array}$

141. Matthew Karnitschnig et al., AIG Faces Cash Crisis as Stock Dives 61\%, WALL ST. J., Sept. 16, 2008, at A1; Mark Pittman, Goldman, Merrill Collect Billions After Fed's AIG $\begin{array}{lllll}\text { Bailout Loans, } & \text { BLOOMBERG.COM, 2008, }\end{array}$ http://www.bloomberg.com/apps/news?pid=newsarchive\&sid=aTzTYtlNHSG8;.

142. See AIG Third Quarter Form 10-Q, supra note 138, at 114.

143. See Karnitschnig et al., supra note 141 .

144. Am. Int'l Group, Inc., Quarterly Report (Form 10-Q), at 1-2 (Aug. 6, 2008), http://sec.gov/Archives/edgar/data/5272/000095012308008949/y59464e10vq.htm.
} 
Reserve, subject to shareholder approval, to obtain up to $79.9 \%$ of the outstanding common stock of AIG (after taking into account the exercise of the warrant). ${ }^{145}$

On September 26, AIG announced that it had entered into definitive agreements with regard to its government assistance. ${ }^{146}$ The Federal Reserve extended an $\$ 85$ billion loan on hard terms. The interest rate was $8.5 \%$ over LIBOR on funds drawn and $8.5 \%$ on undrawn funds plus a $\$ 1.7$ billion commitment fee paid to the Federal Reserve. Moreover, the credit agreement with the Federal Reserve required that AIG's free cash flow be paid over to service the Federal Reserve loan as well as the proceeds of any of AIG's asset disposals or capital raisings. ${ }^{147}$ For security the Federal Reserve received a first priority lien on all of the unregulated assets of AIG. ${ }^{148}$ Due to insurance and other state and federal regulation, this was the limit that the government could receive under current law. The loan terms were better than AIG could have received in the market, but were still clearly designed to force AIG to downsize or perhaps disappear in order to service the debt.

In exchange for providing this loan, the government received AIG preferred shares equivalent to a $79.9 \%$ voting and dividend interest in AIG-the GSE precedent in deals was rapidly becoming the norm. ${ }^{149}$ Though the loan was issued by the Federal Reserve, again pursuant to its authority under $\S 13$, the preferred shares were actually issued to a trust for the benefit of the Treasury Department. ${ }^{150}$ It is unclear why the interest was for the benefit of Treasury and not the Federal Reserve; presumably, this was a matter of control and who would realize the profits. In addition, the government has yet to fully explain why the interest was placed into trust rather than issued directly to the government. The presumption, however, is that the government did this in order to keep a distance between the government and AIG, and provide some colorable pretext to prevent political meddling in the workings of the company. There was also

145. Am. Int'l Group, Inc., Current Report (Form 8-K) (Sept. 18, 2008), http://www.sec.gov/Archives/edgar/data/5272/000095012308011147/y71385e8vk.htm.

Initially, AIG stated that the government would only take up to a $79.9 \%$ interest. This led to speculation that a market loan could be arranged. Rumors were that former AIG CEO Hank Greenberg would arrange an alternative that would prevent shareholders from being wiped out. See Joanna Chung, Former AIG Chief to Outline Alternate Rescue Plan, FIN. TIMES, Oct. 14, 2008, at 30.

146. Am. Int'l Group, Inc., Current Report (Form 8-K) (Sept. 26, 2008), http://sec.gov/Archives/edgar/data/5272/000095012308011496/y71452e8vk.htm.

147. Id. exhibit 99.1 (Credit Agreement by and between American International Group, Inc. and Federal Reserve Bank of New York), at 24.

148. Id. exhibit 99.1, at 42 .

149. Id. exhibit 99.1, at exhibit D.

150. Id. 
the question of whether the Government Corporation Control Act of $1945,{ }^{151}$ which requires congressional authorization in certain circumstances for the government to own private companies, would be violated if the government took full control. When the trust instrument was released three months later, it provided the trustees almost complete control of AIG, an extraordinary delegation of the government's power. ${ }^{152}$ Clearly, matters of open government and the ordinary controls an investor would desire were not the government's goals or perhaps within their grasp given the legal limitations. Again, though, the government had acted to significantly dilute current common stockholders of AIG in a manner comporting with and limited by political and legal realities. Once again, the statutory lever for action was $\S 13$ of the Federal Reserve Act, and, once again, that source of authority explains why it was the Federal Reserve that took action to seize AIG rather than another government institution such as the Treasury Department. The idea was that under the plain language of the statute, interpreted imaginatively, the Federal Reserve could extend credit, upon the right showing, to any company or individual. The Federal Reserve assumed the power to do so and, in effect, included a power to insist on conditions on the loan, like the severe conditions imposed on AIG.

The ordinary details of corporate law were not the sort of hurdles that the government found very worrying. AIG did not have sufficient authorized common stock in its certificate of incorporation to issue warrants to the government, but it did have a "blank check" preferred provision in its certificate. ${ }^{153}$ This type of provision permits a corporation to issue preferred shares on such terms and with such rights as the board deems appropriate. This permitted AIG to issue out 100,000 shares of convertible participating serial preferred stock with rights to $79.9 \%$ of the votes and dividends paid on AIG common and preferred stock. ${ }^{154}$ Once again, the lawyers had innovated to bring about a novel solution to meet the government's dealmaking needs.

New York Stock Exchange (NYSE) Listed Company Manual $\S 312.03$ requires a company to obtain a shareholder vote prior to the issuance of an amount equal to $20 \%$ or greater of its common stock or preferred shares

151. 31 U.S.C. $\$ 9102(2006)$.

152. See Am. Int'l Group, Inc., Current Report (Form 8-K), exhibit 10.1 (AIG Credit Facility Trust Agreement), at 3-10 (Jan. 23, 2009), http:/www.sec.gov/Archives/edgar/data/5272/000095012309001 128/y 74153exv10w1.htm.

153. AIG had 5,000,000,000 common shares authorized and 2,948,038,001 common shares outstanding as of September 30, 2008. AIG Third Quarter Form 10-Q, supra note 138 , at 2 .

154. See Am. Int'l Group, Inc., Current Report (Form 8-K), exhibit D (Sept. 26, 2008), $\mathrm{http} / / / \mathrm{sec}$.gov/Archives/edgar/data/5272/000095012308011496/y71452e8vk.htm. 
convertible into common stock. ${ }^{155}$ This would normally have required AIG to obtain shareholder approval for this issuance. However, there is an exception under NYSE Listed Company Manual $\S 312.05$ if the delay in vote would "seriously jeopardize the financial viability" of a company and "reliance by the company on this exception is expressly approved by the Audit Committee of the Board."156 AIG, a NYSE-listed company, relied upon the exemption to avoid a shareholder vote on the preferred share issuance. ${ }^{157}$ The NYSE had permitted reliance upon this exemption before in the Bear Stearns transaction, and it did so here as well. ${ }^{158}$ It appears that this rule was simply ignored in the case of Fannie and Freddie with the NYSE taking no action. Nonetheless, AIG still was required under Delaware law to hold a shareholder vote to amend its certificate of incorporation to authorize the issuance of the common stock the preferred is convertible into. AIG initially appeared to take the position that the government's preferred shares would be able to vote on the transaction, making approval a foregone conclusion. ${ }^{159}$ However, when a shareholder suit was brought challenging this practice as violating Delaware law, which allowed for a separate class vote of the common shareholders, AIG backtracked and asserted that the common stockholders would separately vote to approve this conversion.

In the months following, the AIG rescue would take up more government resources, showing the perils of ad hoc bailout as the problems with AIG turned out to be more than just short-term liquidity. On October 8 , the New York Federal Reserve agreed to accept up to $\$ 37.8$ billion in investment-grade fixed-income securities from AIG in exchange for cash collateral. The exchange was meant to provide additional liquidity to AIG and allow AIG to exchange that cash for the securities it had lent to third parties. Then on October 27, 2008, the New York Federal Reserve allowed four of AIG's subsidiaries to participate in the Federal Reserve's commercial paper program up to an amount of $\$ 20.9$ billion and to use the proceeds of the loans to prepay moneys borrowed by AIG under AIG's $\$ 85$

155. NYSE LISTED COMPANY MANUAL $\S 312.03$ (2009), available at http://nysemanual.nyse.com/lcm/ (follow "Section 3" hyperlink; then follow "312.00 Shareholder Approval Policy" hyperlink).

156. Id. § 312.05 .

157. See Press Release, Am. Int'l Group, Inc., AIG Notice (Sept. 26, 2008), http://media.corporate-ir.net/media_files/irol/76/761 15/releases/092608a.pdf.

158. See JPMorgan Chase \& Co., Current Report (Form 8-K) (Mar. 24, 2008), http://sec.gov/Archives/edgar/data/19617/000089882208000319/jpm8k.htm.

159. See Posting of Steven M. Davidoff to N.Y. Times DealBook, http://dealbook.blogs.nytimes.com/2008/09/26/notes-from-the-maelstrom/ (Sept. 26, 2008, 12:04 EST). AIG would later back away from this position on the eve of the restructuring of its transaction. See Transcript of Teleconference, Walker v. Am. Int'l Gorup [sic], Inc., No. 4142-CC (Del. Ch. Nov. 7, 2008). 
billion credit facility with the New York Federal Reserve. ${ }^{160}$

On November 10, the government announced another restructuring of its financial support to AIG and the New York Federal Reserve announced two new lending facilities for AIG, again invoking $\S 13$ of the Federal Reserve Act. ${ }^{161}$ This brought the government's potential support for AIG up to $\$ 173.1$ billion. The government's initial thought that the bailout of AIG would cost a mere $\$ 20$ billion was mistaken. But the new rejiggered bailout was a dose of reality - the government had initially failed to comprehensively deal with the AIG situation and the ability of counterparties to demand cash collateral. Instead, the government's punitive actions in the ostensible name of moral hazard had harmed AIG and only hastened this process. The government's new approach was now designed to stabilize AIG rather than dismember it.

But AIG would return to the well for a third time on March 1, 2009, for another $\$ 30$ billion in loan commitments. The government again reworked the terms of its bailout, and the government's aggregate commitments to AIG, excluding the commercial paper program, rose to $\$ 182.5$ billion. ${ }^{162}$

This would explode in public fury the week of March 17, 2009, over the payment of approximately $\$ 165$ million in bonuses to executives at AIG's financial products business. ${ }^{163}$ This was the selfsame business that had entered into the now-infamous credit default swaps (CDSs) contracts that

160. Am. Int'l Group, Inc., Current Report (Form 8-K) (Oct. 30, 2008), http://www. sec.gov/Archives/edgar/data/5272/000095012308013926/y72249e8vk.htm; Matthew Karnitschnig et al., U.S. to Take Over AIG in \$85 Billion Bailout: Central Banks Inject Cash as Credit Dries Up, WALL ST. J., Sept. 17, 2008, at A1. For a more in-depth analysis of the AIG bailouts, see William K. Sjostrom, Jr., The AIG Bailout, 66 WASH. \& LEE L. REV. (forthcoming 2009), available http://papers.ssrn.com/sol3/papers.cfm?abstract_id=1346552.

161. See Press Release, Bd. of Governors of the Fed. Reserve Sys. (Nov. 10, 2008), http://www.federalreserve.gov/newsevents/press/other/20081110a.htm. The government rearranged its $79.9 \%$ ownership interest in AIG in connection with this new deal. Under the EESA, Treasury was required to take an equity interest in connection with any security purchase. However, the amount under the EESA was in the "reasonable" discretion of the Secretary of the Treasury. In the case of AIG the government only received warrants to purchase shares equivalent to $2 \%$ of $\mathrm{AIG}$ 's issued and outstanding shares. This was less than the $15 \%$ value of the total injection Treasury took in other injections. The reason is that if Treasury had taken a warrant amount similar to the other deals, it would have wiped out all of AIG's equity. Nonetheless, the government still negotiated to receive an additional $77.9 \%$ "equity" interest in AIG in connection with the making of the Federal Reserve loan-the same preferred shares previously issued only in a reduced amountbringing its total interest in AIG up to $79.9 \%$ as it was in the initial bailout.

162. Hearing Before the Subcomm. on Capital Markets, Insurance, and Government Sponsored Enterprises of the H. Comm. on Financial Services, 111 th Cong. (2009) (statement of Orice M. Williams, Director, Financial Markets and Community Investment, Government Accountability Office).

163. See Edmund L. Andrews \& Peter Baker, At AIG, Huge Bonuses After $\$ 170$ Billion Bailout, N.Y. TIMES, Mar. 15, 2009, at A1. 
had destroyed AIG. The outrage over these inappropriately structured retention payments-they were paid regardless of performance-was justified. But the outrage was more-it reflected public anger at repeated, unexplained government action that appeared to benefit corporate executives at the expense of the wider public. In the wake of the extreme display of public discontent, President Barack Obama ordered that the government attempt to obtain repayment of the bonuses. ${ }^{164}$

The outcry missed the real issue with AIG, though. In the wake of the public scrutiny, AIG also disclosed that almost $\$ 60$ billion in the government's bailout funds had gone to European banks to satisfy collateral calls. ${ }^{165}$ The $\$ 165$ million was meaningless compared with this $\$ 60$ billion payment.

The government had also allowed these European and American banks to be made whole at 100 cents on the dollar without value to the American taxpayer except for the decaying AIG businesses. In addition, it was also disclosed that the government had repurchased at notional value $\$ 62$ billion worth of securities to unwind AIG's book of CDSs. This payment was made in connection with the November lending facilities and was made despite the fact that these were collateralized at about $57 \%$ of that value. ${ }^{166}$

The payments may have been justified in order to ensure market confidence in AIG and the full repayment of the government funds. In other words, the government now needed to act to ensure that AIG stayed in a suitable operating condition in order to ensure that AIG repaid the tens of billions it still owed to the government. Nonetheless, the failure of the government to adequately justify these payments was yet another source of public discontent.

\section{c. The SEC Takes Action}

One could be excused for wondering where the SEC was during the week that Lehman went bankrupt and AIG almost collapsed. In fact, however, the SEC rarely played an important role at any stage of the crisis. The SEC, after all, was in no position to bail out or backstop the investment banks under its aegis-and, indeed, was forced to eliminate its program

164. See Posting to New York Times DealBook, http://dealbook.blogs.nytimes.com/2009/03/17/obama-in-effort-to-undo-bonuses-at-aig/?scp $=2 \& \mathrm{sq}=$ Obama\%20order\%20bonuses\&st=cse (Mar. 17, 2009, 7:42 EST).

165. Press Release, Am. Int'l Group, Inc., AIG Discloses Counterparties to CDS, GIA and Securities Lending Transactions (Mar. 15, 2009), http://www.aig.com/ aigweb/internet/en/files/Counterparties150309RELonly_tcm385-155648.pdf.

166. See Posting of Steven M. Davidoff to New York Times DealBook, http://dealbook.blogs.nytimes.com/2009/03/17/seven-sad-truths-about-aig/ (Mar. 17, 2009, 12:42 EST). 
overseeing those banks. During the week that changed everything, the SEC did act, however; it intervened in the market place itself, initiating a muchcriticized ban against short sellers. It followed that ban up with an accounting clarification that also proved to be somewhat controversial. And its remaining activities tended toward longer term investigations rather than immediate action. Nonetheless, these actions were symbolic more than substantive. When looking back at the SEC's actions, it appears that the SEC, lacking regulatory power and sidelined by the Federal Reserve and Treasury, was acting more to show that it was indeed acting and providing value, however questionable, than for any holistic or integritydriven regulatory purpose.

Short selling, where the seller borrows a share, sells it immediately, and repays the original seller later (after, the seller hopes, the price of the share has declined), is a well-worn feature of securities markets-as is the criticism of the practice by the CEOs of the companies that are shorted and a minority of academic economists. ${ }^{167}$ In the post-Bear Stearns stage of the crisis, the SEC announced investigations into market manipulationwidely perceived to be a warning that it would investigate short sellers who spread false rumors about companies. ${ }^{168}$ When those investigations did not reduce the quantity of shorting, it banned the practice, albeit temporarily. The SEC's bans on shorting, passed as emergency rules in the wake of the post-Lehman and AIG collapses and then partly extended through some awkward interim temporary final rules for the better part of a year, occasioned criticism from many market participants and economists.

The criticism turned, in part, on the overinclusiveness of the ban, which the SEC announced as a mechanism to protect financial stocks but which turned into something more. The exchanges that administered the rules quickly let seemingly anyone take advantage of the ban, listing companies such as GE, IBM, and auto manufacturers among those who volunteered to be covered by the ban. ${ }^{170}$ After its temporary ban on naked shorting and any short selling of financial and other stocks expired, the SEC adopted "interim temporary final rules" that extended the naked shorting ban and forced some hedge funds to report their shorts on a weekly basis - a

167. See Itay Goldstein \& Alexander Guembel, Manipulation and the Allocational Role of Prices, 75 REv. ECON. STUD. 133, 133-35 (2008) (arguing that short selling manipulates price information, distorting resource allocation and reducing economic efficiency).

168. For background, see Press Release, SEC, SEC Expands Sweeping Investigation of Market Manipulation (Sept. 19. 2008), http://sec.gov/news/press/2008/2008-214.htm.

169. See Tom Lauricella et al., SEC Extends 'Short' Ban as Bailout Advances, WaLL ST. J., Oct. 2, 2008, at C1.

170. See SEC Short Ban List Now Covers More than 900 Firms, REUTERS, Sept. 22, 2008 , http://www.forbes.com/reuters/feeds/reuters/2008/09/22/2008-0922T223757Z_01_N22281931_RTRIDST_0_SHORTSELLING-SEC-UPDATE-3.html. 
controversial decision, given that it had the potential to reveal the trading strategies of the funds, which they regard as proprietary. The rules also extended the SEC's ban on naked shorting ${ }^{171}$ and required large hedge-fund managers to disclose their shorts, a controversial move given that hedge funds are very secretive about their trading strategies. ${ }^{172}$

As for accounting, shortly after banning shorting, the SEC issued a clarification about "fair value" accounting, an alternative to the mark-tomarket accounting which, now that the market was heavily discounting mortgage-related assets, was devastating the balance sheets of publicly traded financial institutions. As the SEC's chief accountant explained, "When an active market for a security does not exist, the use of management estimates that incorporate current market participant expectations of future cash flows, and include appropriate risk premiums, is acceptable." 173 Although it is unclear whether this clarification departed materially from already-extant accounting standards, the implication was clear: companies that relied on fair value accounting could presume that they would not be targeted by SEC enforcement. The agency also began a longer term study on mark-to-market accounting. ${ }^{174}$

The short ban was quite controversial, but the SEC's other crisis-related actions were decidedly less so because they did not appear to be particularly meaningful solutions. For example, it was not so controversial to investigate the quality of credit-rating-agency evaluations of the mortgage-backed financial instruments that led to the crisis-but that was just an investigation, ${ }^{175}$ and one that drew its criticisms of the work of the financial ratings agencies rather late in the progression of the crisis. ${ }^{176}$ Nor was the SEC's ongoing auction-rate-securities investigation particularly

171. Amendments to Regulation SHO, 73 Fed. Reg. 61,706 (Oct. 17, 2008) (to be codified at 17 C.F.R. pt. 242), available at http://www.sec.gov/rules/final/2008/3458773.pdf. Naked shorting is an often-criticized practice where a stock is shorted without actually borrowing it.

172. Disclosure of Short Sales and Short Positions by Institutional Investment Managers, 73 Fed. Reg. 61,678 (Oct. 17, 2008) (to be codified at 17 C.F.R. pts. 240 \& 249), available at $\mathrm{http} / /$ www.sec.gov/rules/final/2008/34-58785.pdf.

173. Press Release, SEC, SEC Office of the Chief Accountant and FASB Staff Clarifications on Fair Value Accounting (Sept. 30, 2008), http://sec.gov/news/press/2008/2008-234.htm.

174. See Press Release, SEC, SEC Commences Work on Congressionally Mandated Study on Accounting Standards (Oct. 7, 2008), http://sec.gov/news/press/2008/2008242.htm.

175. See Press Release, SEC, SEC Proposes Comprehensive Reforms to Bring Increased Transparency to Credit Rating Process (June 11, 2008), http://sec.gov/news/press/2008/2008-1 10.htm.

176. See Press Release, SEC, SEC Examinations Find Shortcomings in Credit Rating Agencies' Practices and Disclosure to Investors (July 8, 2008), http://sec.gov/news/press/2008/2008-135.htm. 
interesting, though the agency would trumpet the settlements made in the investigation as part of the government's financial crisis response. ${ }^{177}$

Former SEC Chairman Christopher Cox has said that "[n]ever in this agency's history has this fundamental mission been more relevant, and more urgent." 178 But the SEC will probably review its performance during the crisis and wonder about its regulatory relevance, let alone the urgency of its role as a market watchdog. The SEC has played a peripheral role in the government's response to the financial crisis-even though the collapse of two investment banks that it putatively regulated both announced and greatly exacerbated the crisis.

During that response the scope of the SEC's mission has, if anything, declined: the agency has lost its authority to oversee the investment banks after the failures of Bear Stearns and Lehman. It had nothing to say about Merrill Lynch as that investment bank concluded a quick merger with Bank of America in the wake of Lehman's failure. In addition, as the bailout began to take shape, the SEC appeared to play little part in the work of the Federal Reserve and the Treasury Department in devising a government response. While those agencies, for example, were devising the bailout, the SEC reminded investors that broker accounts are insured by the Securities Investor Protection Corporation (SIPC), ${ }^{179}$ celebrated the speedy acquisition of Lehman's bankrupt remains by Barclays, ${ }^{180}$ and announced that it would be putting possible market manipulators under oath. ${ }^{181}$ All of this occurred in the midst of a sense of malaise within the agency. As the New York Times reported after the Bear Stearns failure, "Staff lawyers in the S.E.C. enforcement division say high turnover, tight budgets and a new, looser attitude toward corporate wrongdoing are sapping morale. The

177. See Press Release, SEC, Citigroup Agrees in Principle to Auction Rate Securities Settlement (Aug. 7, 2008), http://sec.gov/news/press/2008/2008-168.htm. The premise behind the auction-rate-securities investigations was that these banks had promised investors that they could sell certain long-term securities at weekly auctions, making the securities quite liquid. But when the credit markets began to tighten in early 2008, the auctions failed, and banks refused to purchase the securities in lieu of a buyer. The SEC investigations into auction-rate-securities representations mostly preceded the heart of the financial crisis, but they were not entirely unrelated to the general tightening of credit that began once the housing bubble popped. See Jenny Anderson \& Vikas Bajaj, New Trouble in Auction-Rate Securities, N.Y. TIMES, Feb. 15, 2008, at C6.

178. See Christopher Cox, Chairman, SEC, Opening Remarks at SEC Roundtable on Modernizing the Securities and Exchange Commission's Disclosure System (Oct. 8, 2008), http://sec.gov/news/speech $/ 2008 /$ spch $100808 \mathrm{cc} . \mathrm{htm}$.

179. See Press Release, SEC, Statement of SEC Division of Trading and Markets Regarding the Protection of Customer Assets (Sept. 20, 2008), http://sec.gov/news/press/2008/2008-216.htm.

180. See Press Release, SEC, SEC Acts to Support Swift Court Approval of Barclays Acquisition of Lehman Brothers, lnc. (Sept. 20, 2008), http://sec.gov/news/press/2008/2008-215.htm.

181. See Press Release, SEC, supra note 168. 
staffing and budget of the S.E.C. have lagged far behind the explosive growth of the markets the commission must police." 182

The result of the crisis may be especially unkind to the SEC, which appears likely to become a consumer protection and prosecution shop rather than a tool the government can use to address systemic risk in finance. This latter power now appears much more likely to stay with the Federal Reserve or Treasury Department. In a move consistent with public choice stories about agencies, ${ }^{183}$ the SEC has sought new turf to replace its old turf. It has since asked Congress for the authority to regulate credit default swaps - the form of insurance that contributed to AIG's fall. It has also sought congressional legislation for a precise role for SEC supervision of the brokerage arms of the investment banks. ${ }^{184}$

The SEC has played this role before-after the fall of Enron in 2001, it sought more authority to make up for its failure to identify the company's wrongdoings, and received it in Sarbanes-Oxley. But while it may achieve more consumer-like authority over the financial markets, we believe it is likely that the real systemic powers to be granted in the coming regulatory reform will go to the Federal Reserve and Treasury. ${ }^{185}$ If this occurs, then in the grand-scale regulatory turf wars, the SEC will be a net loser.

\section{d. The Treasury Guarantees the Money Market System}

The bankruptcy of Lehman and the nationalization of AIG had a terrible effect on the financial markets, not least because of all the counterparties wiped out by Lehman's bankruptcy. Panic gripped lenders and the credit markets began to shut down overnight. Market participants acted on fear and information asymmetry-at this point any mortgage-related assets held by financial institutions were poison to be valued as worthless at best-to

182. Jenny Anderson, A Fear that the Market's Watchdog Is Losing Its Bite, N.Y. TiMES, Apr. 8, 2008, at Cl.

183. But see Daryl J. Levinson, Empire-Building Government in Constitutional Law, 118 HARV. L. REV. 915, 921-22 (2005) (arguing that the evidence of unfettered turf accumulation is mixed at best).

184. Turmoil in U.S. Credit Markets: Recent Actions Regarding Government Sponsored Entities, Investment Banks and Other Financial Institutions: Hearing Before the S. Comm. on Banking, Housing and Urban Affairs, 110 th Cong. 6 (2008) (statement of Christopher Cox, Chairman, U.S. Securities and Exchange Commission), http://banking.senate.gov/public/index.cfm?FuseAction=Files.View\&FileStore_id=cl7161d 3-a5f7-4544-9ade-7dc2197ddce0 ("With each of the remaining major investment banks now constituted within a bank holding company, it remains for the Congress to codify or amend as you see fit the Memorandum of Understanding between the SEC and the Federal Reserve, so that functional regulation can work.").

185. This appears to be the intent of the current regulatory reform proposals put forth by the Obama Administration. See U.S. DeP'T OF THE TrEasury, Financial Regulatory REFORM (2009), http://www.financialstability.gov/docs/regs/FinalReport_web.pdf. 
move funds to more secure assets. The dollar LIBOR rate on overnight lending went from $2.15 \%$ on September 12 to $6.44 \%$ on September $16 .{ }^{186}$ Meanwhile, in a sign that the markets were beginning to lose confidence in financial institutions, credit default swaps on Morgan Stanley's and Goldman Sachs's debt rose dramatically. ${ }^{187}$ As this panic and follow-on effects from the Lehman bankruptcy and AIG nationalization spread, other, normally staid areas of finance were thrown into turmoil. Perhaps most perilously, money market funds came very close to their own sort of unprecedented collapse. These funds had for decades provided a great deal of unexciting credit to the financial markets, usually by investing in shortterm bonds and commercial paper. ${ }^{188}$

The returns on such funds were rarely impressive, but the risks of holding them had always been thought to be minimal. That is, until September 16, when the Reserve Primary Fund declared that it had "br[oken] the buck," meaning that every dollar invested in the fund was, as of the 16th, worth less than a dollar. ${ }^{189}$ Reserve Primary broke the dollar floor after writing off $\$ 785$ million in Lehman Brothers debt. ${ }^{190}$ Investors never suspected that they could be susceptible to these kinds of losses; Reserve Primary was a blue-chip fund in a blue-chip industry: at the beginning of September it was worth $\$ 64.8$ billion, and, in addition to being massive, it was the oldest money market fund in the country. ${ }^{191}$

Money market funds had essentially never lost money (on one other occasion, in 1994, a small fund broke the buck), and the fall set off a wave of shocked withdrawals by investors in the funds. ${ }^{192}$ The resulting outflow of money was remarkable, even for an industry that has always offered easy entry and exit; Reserve Primary's assets plunged more than $60 \%$ to $\$ 23$ billion in two days. ${ }^{193}$ Other funds admitted that they too had suffered substantial losses from the disappearance of Lehman, which was an enormous producer of the commercial paper that was the bread and butter

186. BRITISH BANKERS' ASS'N, supra note 22.

187. See DBRS Lowers Outlook on Morgan Stanley, Goldman Ratings, REUTERS, Sept. 17, 2008, http://www.reuters.com/articlePrint?articleId=USN1751866920080917 ("The cost of protecting Morgan Stanley and Goldman debt with credit default swaps rose on Wednesday, reflecting investor uncertainty about the financial sector. Five-year CDS on Morgan Stanley rose by 40 basis points to 796 basis points.").

188. These funds are required by the SEC to hold debt that matures in ninety days, by weighted average. See Christopher Condon, Reserve Primary Money Fund Falls Below \$1 a Share, BLOOMBERG.COM, Sept. 16, 2008, http://www.bloomberg.com/apps/news?pid=20601087\&sid=aAj 1 pHOSthQA\&refer=home.

189. Id.

190. Id.

191. Id.

192. See John Waggoner, Money Market Fund Breaks a Buck, USA TODAY, Sept. 17, 2008 , at 4B.

193. See Condon, supra note 188. 
of the money markets. ${ }^{194}$

The results were close to catastrophic for the industry, as the funds experienced substantial investor flight to treasury bonds and other asset classes. Over that week, $\$ 170$ billion of investor funds flowed out of the money market institutions. ${ }^{195}$ The follow-on effects of this collapse were potentially even more catastrophic - if the money market system collapsed, the principal purchaser of commercial paper would disappear from that market. If that happened, hundreds of U.S. corporations would no longer be able to finance their working capital at a time when credit on that scale was largely unavailable. For perhaps the third time that week, a financial doomsday seemed to loom.

The government once again substantially stretched its regulatory authority to act quickly to preserve the assets of the country's principal purchasers of short-term debt. On September 19, the Treasury Department announced that it would insure the funds up to a ceiling of $\$ 50$ billion. ${ }^{196}$ As the Department explained, its goals were to "provide[] support to investors in funds that participate in the program and [assure that] those funds will not 'break the buck" and "alleviate investors' concerns about the ability for money market mutual funds to absorb a loss."197

The program was created and financed through a novel use of Treasury's supervision of an obscure pile of assets on hand for international currency crises. Treasury based its power to insure the money market on the Gold Reserve Act of $1934 .{ }^{198}$ That statute created the Exchange Stabilization Fund (ESF), which permitted the Department to hold gold and various currencies to deal with macro shocks to the economy. ${ }^{199}$ As amended in the late 1970s, the Gold Reserve Act, another Depression-era-style broad grant of authority, provided in relevant part that

[t] he Department of the Treasury has a stabilization fund.... Consistent with the obligations of the Government in the International Monetary Fund on orderly exchange arrangements and a stable system of exchange rates, the Secretary ..., with the approval of the President, may deal in gold, foreign

194. Evergreen Investments, a money market fund owned by Wachovia, for example, had to be bailed out by its parent to avoid breaking the buck. See Daisy Maxey, Wachovia to Bolster Evergreen Funds, More Support to Come, Dow JONES NEWSWIRES, Sept. 15, 2008, http://lloyds.com/CmsPhoenix/DowJonesArticle.aspx?id=404668.

195. See Diana B. Henriques, Treasury to Guarantee Money Market Funds,

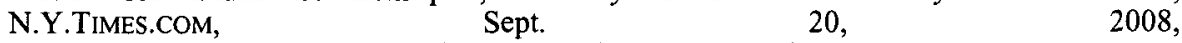
http://www.nytimes.com/2008/09/20/business/20moneys.html.

196. Press Release, U.S. Dep't of the Treasury, Treasury Announces Guaranty Program for Money Market Funds (Sept. 19, 2008), http://www.treasury.gov/press/releases/hp1147.htm.

197. Id.

198. Id.

199. U.S. Dep'T OF THE TREasury, Exchange Stabilization Fund: InTROduction (2007), http://www.treas.gov/offices/international-affairs/esf/. 


\section{exchange, and other instruments of credit and securities. ${ }^{200}$}

Treasury concluded that "other instruments" could be interpreted to permit it to provide guarantees for money market funds, although funds like Reserve Primary dealt largely in dollars, and the Gold Reserve Act was clearly aimed at non-dollar-denominated wealth. Treasury also obtained the President's approval for the interpretation, as the text of the statute required. ${ }^{201}$

Treasury's money market insurance had takers in the two weeks following the announcement, including "some of the nation's largest mutual fund companies," as the New York Times reported, but it failed to unfreeze the short-term credit markets. ${ }^{202}$ Moreover, its failure mimicked, at least initially, the government's other foray into short-term credit in the aftermath of the fall of Lehman and AIG. ${ }^{203}$ The Federal Reserve also enacted an initial money market financing facility on September 18, one day before Treasury announced its money market insurance program. ${ }^{204}$ One month later, the Federal Reserve bolstered its own money market relief program by pairing it with a facility that would both finance and purchase the commercial paper and short-term debt that were the stock in trade of money market funds. ${ }^{205}$

The Exchange Stabilization Fund-backed insurance was also a shortlived program. Congress quickly acted to make the ESF program a onetime-only program. The final version of EESA provided that the Secretary was "prohibited from using the Exchange Stabilization Fund for the establishment of any future guaranty programs for the United States money market mutual fund industry," 206 and the House report accompanying the bill made it very clear that the program was designed to "[p]rotect[] the Exchange Stabilization Fund from incurring any losses due to the temporary money market mutual fund guarantee by requiring the program created in this Act to reimburse the Fund [and p]rohibit[] any future use of the Fund for any guarantee program for the money market mutual fund

200. 31 U.S.C. $\S 5302(a)(1)$, (b) (2000) (emphasis added).

201. Id. § 5302(b).

202. Diana B. Henriques, As Cash Leaves Money Funds, Financial Firms Sign Up for U.S. Protection, N.Y. Times, Oct. 2, 2008, at Cl0.

203. That second foray was the decision by the Federal Reserve to establish its own program to purchase commercial paper (the sort of short-term bonds issued by financial institutions like Lehman and large companies like GE).

204. FED. ReSERVE, ASSET BaCKed COMMERCIAL PAPER (ABCP) MONEY MARKeT MUtUAL FUND (MMMF) LIQUIDITY FACILITY (AMLF OR "THE FACILITY"), http://www.frbdiscountwindow.org/mmmf.cfm?hdrID=14 (last visited June 9, 2009).

205. Press Release, Bd. of Governors of the Fed. Reserve Sys. (Oct. 21, 2008), http://www.federalreserve.gov/newsevents/press/monetary/2008102 la.htm.

206. Emergency Economic Stabilization Act of 2008, Pub. L. No. 110-343, § 131, 122 Stat. 3797 (2008) (to be codified at 12 U.S.C. $\$ 52336$ ). 
industry. $" 207$

That statute was passed on October 4, meaning that the effective ongoing life of the money market insurance gambit was roughly a fortnight. $^{208}$ It nonetheless exemplified the novel market participation being tried by the government as the crisis worsened and the at least shortterm failure of many of those first stretches of regulatory authority to permit participation in new capital markets. Rather than being a central part of the government's response to the crisis, the money market fund insurance policy is interesting more as an example of it. Ad hoc, marked by a rapid response to unprecedented financial market chaos, and authorized by an unconventional interpretation of a Depression-era statute that created a program meant to do something else, Treasury's money market adventure looked quite like the Federal Reserve's own novel forays into support of the financial markets, even if there was little else consistent about what the government was up to.

\section{The End of the Beginning: Government as Deal Machine}

\section{The Bankruptcy of Washington Mutual}

The Washington Mutual (WaMu) and Wachovia transactions occurred while the EESA was being debated and eventually passed. Both of these institutions and a number of other large consumer banks were, at the time, suffering from slow-motion bank runs. The government's rescue efforts of WaMu and Wachovia aptly illustrated the government's dealmaking skills. $^{209}$ In WaMu's demise, the FDIC was the primary governmental actor. Pursuant to its authorization under the Federal Deposit Insurance Act, on September 25, the FDIC seized the bank depositary assets of WaMu and sold them to JPMorgan for a $\$ 1.9$ billion cash payment. ${ }^{210}$ The FDIC announced this transaction without informing the WaMu management. In fact, the CEO of WaMu was on a plane at the time, unaware that his company's depositary assets had been seized. ${ }^{211}$ It was

207. H. Comm. on Fin. Servs., $111 \mathrm{Th}$ CONG., Section-By-Section Analysis of the LEGISLATION (2009), http://www.financialservices.house.gov/essa/final_bill_section-bysection.pdf.

208. Congress did not eliminate the program through the EESA, as some earlier drafts of the bill suggested.

209. National City Corp. would subsequently also be acquired by PNC Financial Services Group, Inc. in a government-supported transaction. See Press Release, PNC Financial Services Group, PNC to Acquire National City (Oct. 24, 2008), http://pnc.mediaroom.com/index.php?s=43\&item $=591$.

210. See Robin Sidel et al., WaMu Is Seized, Sold Off to J.P. Morgan, in Largest Failure in U.S. Banking History, WALL ST. J., Sept. 26, 2008, at A1.

211. Id. 
subsequently disclosed that the FDIC had decided to engineer this transaction over a week before. ${ }^{212}$ The FDIC had prearranged JPMorgan's purchase; JPMorgan had even been able to confidentially undertake a $\$ 10$ billion capital raising before and in connection with this purchase. ${ }^{213}$ The day after the FDIC's seizure and sale, the remaining independent holding company of WaMu filed for bankruptcy. ${ }^{214}$ TPG, which had invested $\$ 1.35$ billion in WaMu in April 2008, lost its entire investment, one of the largest and quickest losses by a private equity firm ever. ${ }^{215}$

\section{The Forced Sale of Wachovia}

The collapse and workout of Wachovia unfolded in a less orderly manner, again showing the limits of government power. As of the weekend of September 27, Wachovia appeared to be insolvent. The FDIC was again the primary government actor; in a hectic weekend, the FDIC selected Citigroup as the acquirer for Wachovia's depositary assets. In choosing Citigroup, the FDIC was expressing the government preference for orderly as opposed to market solutions. The FDIC refused to support a competing offer by Wells Fargo to acquire the entirety of Wachovia and a proposal by Wachovia itself to maintain it as a stand-alone entity. On Monday, September 29, Citigroup and Wachovia executed an exclusivity agreement, pursuant to which the parties agreed to negotiate definitive documentation for Citigroup to purchase the depositary assets of Wachovia for $\$ 2.1$ billion. $^{216}$ Wachovia would remain a functioning company operating a rump business consisting of "Wachovia Securities, which combined with A.G. Edwards is the nation's third largest brokerage firm ... and Evergreen Investments, which is Wachovia's asset management business, as well as Wachovia retirement services and Wachovia's insurance brokerage businesses." 217

Citigroup's plans were disrupted, however, when Wells Fargo decided to again bid for Wachovia on that Thursday. Wells Fargo likely did so because of the imminent passage of the EESA, which would permit Wells Fargo to utilize $\$ 74$ billion in Wachovia's carryforward losses, a tax

212. Id.

213. See Posting of Heidi N. Moore to Deal Journal, http://blogs.wsj.com/deals/ 2008/09/29/how-jp-morgan-raised-1 15-billion-in-24-hours/ (Sept. 29, 2008, 9:03 EST).

214. Peg Brickley, Washington Mutual Files for Chapter 11 Bankruptcy, Dow JoNES NEWSWIRES, Sept. 29, 2008, http://English.capital.gr/NewsPrint.asp?id=585174.

215. See Peter Lattman, WaMu Fall Crushes TPG, Wall St. J., Sept. 27-28, 2008, at B1.

216. Wachovia Corp., Current Report (Form 8-K), at 2 (Sept. 29. 2008), http://sec.gov/Archives/edgar/data/36995/0001 19312508203284/d8k.htm.

217. Id. 
advantage that now made this acquisition quite financially attractive. ${ }^{218}$ This time the FDIC provided its approval to this transaction and, in fact, informed Wells Fargo that if a merger proposal was not signed by October 3, Wachovia's banking subsidiaries would be put into receivership. That Thursday night, October 2, Wells Fargo and Wachovia agreed to a merger agreement for Wells Fargo to acquire the entirety of Wachovia for approximately $\$ 15.1$ billion. $^{219}$ Here, we see the FDIC's actions as acknowledging the legal realities that under the agreements Citigroup and Wachovia had signed, Wells Fargo could still make a competing bid.

Wells Fargo's lawyers were from Wachtell, Lipton, Rosen \& Katz, the same law firm who represented JPMorgan in the Bear Stearns acquisition, and they negotiated an agreement with similar features as the one in Bear Stearns. Wachovia agreed to a force-the-vote provision modeled on the one in the Bear agreement that required the company to rehold its shareholder meeting to approve the merger repeatedly during a six-month period after a first "no" vote on the transaction. ${ }^{220}$ Wachovia also issued ten shares of preferred stock to Wells Fargo in exchange for one thousand shares of Wells Fargo, equivalent to a $39.9 \%$ preferred share interest in Wachovia. $^{221}$ Wells Fargo could use these shares to approve the transaction. As Bear and AIG did, Wachovia sidestepped the NYSE Rules on a shareholder vote for this issuance by invoking the "insolvency" exception, asserting that Wachovia would have had to file bankruptcy without this transaction. ${ }^{222}$

Citigroup sued Wells Fargo and Wachovia in New York state court that Saturday and the parties litigated in state and federal court over the weekend as Citigroup attempted to salvage its deal in the courts. ${ }^{223}$ However, on Tuesday the FDIC privately intervened and forced the parties to halt their litigation and sign a tolling agreement in order to negotiate a resolution. The FDIC then attempted to mediate a deal, but when Citigroup and Wells Fargo could not agree on a resolution, Citigroup dropped its bid for these assets and Wells Fargo proceeded to acquire Wachovia. ${ }^{224}$ The government's preference in these matters for an ordered solution to a

218. Eric Dash \& Ben White, Wells Fargo Swoops In, N.Y. Times, Oct. 4, 2008, at C1.

219. See Wachovia Corp., Current Report (Form 8-K), exhibit 99(a) (Merger News Release) (Sept. 29, 2008) [hereinafter Wachovia Form 8-K], http://sec.gov/Archives/edgar/data/36995/000119312508205973/dex99a.htm.

220. Id. exhibit 2.1 (Merger Agreement), at 29, 32.

221. Id. exhibit 2.2 (Share Exchange Agreement).

222. Id.

223. See Posting of Steven M. Davidoff to N.Y. Times DealBook, http://dealbook.blogs.nytimes.com/2008/10/05/the-mad-dash-to-a-legal-victory/ (Oct. 5, $2008,22: 49$ EST) (detailing the litigation between the parties during that weekend).

224. Francesco Guerrera \& James Politi, Wells Set to Acquire Wachovia in $\$ 11.7 \mathrm{bn}$ Deal After Citi Pulls Out, Fin. Times, Oct. 10, 2008, at A17. 
designated bidder had once again been in evidence. Citigroup had, in hindsight, made a mistake in failing to lock up Wachovia, and Wells Fargo had forced the government to allow a market solution. Wells Fargo, given a measure of government endorsement due to its superior legal position, had once again showed that acquirers in such circumstances were not afraid to push the envelope on the law. Here, Wells Fargo and its lawyers followed the path first tread by JPMorgan in its Bear acquisition. Again, a government-backed acquisition had substantially stretched but not broken the laws for the structuring of an acquisition, safe in the assumption that the courts would not want to intervene.

\section{The Saving of Morgan Stanley}

The last pre-EESA episode of government as dealmaker occurred over the weekend of October 11. On Friday, October 10, 2008, it did not appear that Morgan Stanley would survive the weekend. The S\&P 500 Index had declined $18 \%$ that past week, mirroring a decline with the rest of the general stock market. ${ }^{225}$ Morgan Stanley closed at the end of Friday at $\$ 9.68$ a share, down $57 \%$ in the space of a week. ${ }^{226}$ The next Tuesday, October 14, Morgan Stanley was scheduled to close its $\$ 9$ billion investment from Mitsubishi Bank for $21 \%$ of Morgan at a price of at least $\$ 25.25$ per share. ${ }^{227}$ However, the stock price of Morgan reflected a heightened publicly perceived risk that this injection would not occur. Morgan Stanley was now trading with a market capitalization less than Mitsubishi's entire investment. ${ }^{228}$ Mitsubishi had signed a definitive purchase agreement for this transaction, but over that weekend invoked the material adverse change clause in the agreement. ${ }^{229}$

The government responded in this case to assure a deal. Reportedly over that weekend the Treasury Department had privately assured Morgan that it

225. See Google Finance, S\&P 500 Index Historical Prices, http://www.google.com/finance/historical? $\mathrm{cid}=626307 \&$ startdate $=\mathrm{Oct}+6 \% 2 \mathrm{C}+2008 \&$ endda te $=$ Oct $+10 \% 2 \mathrm{C}+2008$ (last visited July 30,2009 ).

226. Google Finance, Historical Prices for Morgan Stanley, http://finance.google.com/finance/historical?q=NYSE:MS\&start=125\&num=25 (last visited Apr. 8, 2009).

227. Press Release, Morgan Stanley, Mitsubishi UFJ Financial Group to Invest $\$ 9$ Billion in Morgan Stanley (Sept. 29, 2008), http://www.morganstanley.com/about/press/articles/6962.html; see also Morgan Stanley, Inc., Current Report (Form 8-K), exhibit 10.1 (Securities Purchase Agreement) (Oct. 3, 2008), http://www.sec.gov/Archives/edgar/data/895421/000089882208000945/body8k.htm.

228. See Posting to N.Y. Times DealBook, http://dealbook.blogs.nytimes.com/ 2008/10/10/morgans-market-value-falls-below-mitsubishi-deal-price/ (Oct. 10, 2008, 13:04 EST).

229. See Andrew Ross Sorkin, Morgan Is Backed: Fed Offers Assurances for Japanese Bank's Investment, N.Y. TIMES, Oct. 13, 2008, at A1. 
would support the investment bank if the Mitsubishi investment failed. The government also provided assurances to Mitsubishi that if the government was subsequently forced to provide capital to Morgan it would not significantly dilute Mitsubishi's investment. ${ }^{230}$ The government's prior requirement that shareholders be significantly harmed in any bailout was beginning to inhibit private solutions as parties refused to invest, fearful of later government action. It was at this point that the government abandoned this position for future transactions. With these government assurances, Morgan Stanley and Mitsubishi agreed to a minor reworking of their transaction; on Monday the investment completed and Mitsubishi invested the full $\$ 9$ billion in Morgan. ${ }^{231}$

After the Morgan transaction, the government would have one more surprise deal left, its biggest of all, the $\$ 125$ billion investment forced upon the nine largest U.S. financial institutions. This would mark a change in the government's approach as it turned from dealmaker to administrator of the Troubled Asset Relief Program (TARP). In order to understand the government's final spate of dealmaking in this period, it is first necessary to turn to the EESA and its negotiation and underpinnings.

\section{THE GOVERNMENT TAKES COMPREHENSIVE ACTION}

After the government decided to act comprehensively, the result was a departure from ad hoc deals but not-at least not entirely-from ad hoc dealmaking. In this Part, we analyze the legislative process that went into the bailout and the terms of the bailout itself. As we have already suggested, although the financial crisis was rooted in the decline of the property market, the variety of short-term shocks and intermediate emergencies that characterized its day-to-day and week-to-week evolution shaped the way the government responded to it. After the failure of Lehman and near failure of the other investment banks contributed to the quick decline in the availability of short-term credit, unprecedented problems in the money market sector of the financial industry, and a knockon effect on a number of other banks, the Treasury and Federal Reserve changed course in that week that changed the world. The two agencies announced that a comprehensive solution to the financial crisis would now be required, one that would necessitate the imprimatur of Congress.

Clearly, the government's ad hoc strategy was failing and a greater response was needed. But the Federal Reserve had, up to that point, spent

230. Id.

231. See Press Release, Morgan Stanley, Mitsubishi UFJ Financial Group Closes $\$ 9$ Billion Equity Investment in Morgan Stanley as Part of Global Strategic Alliance (Oct. 13, 2008), http://www.morganstanley.com/about/press/articles/7025.html. 
many of its own billions in bailing out the investment banks and injecting liquidity into the capital markets. In addition, the government was using Fannie and Freddie to purchase up to $\$ 40$ billion in underperforming mortgage-backed securities per month. ${ }^{232}$ The government, no doubt, could have continued to provide liquidity and even conducted the mortgagerelated asset purchases it would propose to Congress with its current authority. So, Why did it now turn to Congress?

We believe that that the government's turn to Congress was for three reasons. First, a significant government action was likely necessary to restore confidence in the market and allow for investors to return to the marketplace. Second, foreign regulators were beginning to act in a more holistic manner, raising the possibility of capital flight abroad to morestable government-backed financial institutions. Finally, although the Federal Reserve had a substantial amount of funds at its disposal, the Treasury Department did not, and neither of these institutions had very clearly delineated authority to intervene flexibly and comprehensively in the financial markets. Going to Congress for additional authority allowed for a more comprehensive and regulatory-defined response. The government may have wanted to get some legislative assent to its ever more unprecedented interventions in the economy. ${ }^{233}$ Moreover, it is also possible that the Treasury Secretary grew tired of relying on the independent and difficult to oversee Federal Reserve to implement its preferred rescue approaches. ${ }^{234}$ The result was a turn away from the dealto-deal approach and toward Congress. But in turning toward Congress, the government was also allowing for more political future dealmaking by recentering legal authority for the bailout away from the Federal Reserve and to the Treasury Department.

\section{A. The Paulson Proposal and the Congressional Reaction}

The text of the first draft of the bailout bill submitted to Congress came from the Treasury Department on September 20, with all the hallmarks of emergency; there has never been a shorter draft statute that would have committed such a large amount of money. Treasury sought at least $\$ 700$

232. Dawn Kopecki, Fannie, Freddie to Buy $\$ 40$ Billion a Month of Troubled Assets, BLOOMBERG.COM, Oct. 11, 2008, http://www.bloomberg.com/apps/news?pid=20601103\&sid=aDjJYMSphyM0\&refer=news.

233. Many of the commentators on the bailout will no doubt, for reasons along these lines, analogize the bailout to the use of force authorization that preceded the 2003 invasion of Iraq. For a libertarian version of such fears, see Ron Paul, Commentary: Bailouts Will Lead to Rough Economic Ride, CNNPolitics.COM, Sept. 23, 2008, http://www.cnn.com/2008/POLITICS/09/23/paul.bailout/.

234. See Hilsenrath et al., supra note 7 (chronicling the debate between the Federal Reserve and Treasury regarding the government's response to the financial crisis). 
billion taxpayer dollars to purchase the troubled, difficult-to-value, and impossible-to-sell mortgage-related assets of financial institutions. This socalled Paulson proposal was three pages long and consisted of 849 words. ${ }^{235}$

Under the Paulson proposal, Treasury would be empowered to "purchase, and to make and fund commitments to purchase, on such terms and conditions as determined by the Secretary, mortgage-related assets from any financial institution having its headquarters in the United States." 236 To do this, Treasury was to be allowed to sell "securities" to raise the $\$ 700$ billion necessary, and could have no more than " $\$ 700,000,000,000$ outstanding at any one time," a requirement that would have permitted the Secretary to loan out more than that amount in total, as long as he was able to sell off previously acquired assets. ${ }^{237}$ Moreover, the bill authorized Treasury to implement the bailout via wide-ranging powers, including the right to appoint personnel and manage these assets. ${ }^{238}$

The limitations on Treasury's power were threefold. First, the draft contained a two-year sunset clause, a characteristic congressional imposition for controversial modern legislation. ${ }^{239}$ Second, the draft required the Treasury secretary to report to Congress on the process of

235. See Posting to N.Y. Times DealBook, Sept., 20 2008, http://dealbook.blogs.nytimes.com/2008/09/20/the-bush-administrations-700-billion-rescueplan/ (Sept. 20, 2008, 11:29 EST). The word count was obtained through Microsoft Word's word-count function.

236. See 110 Th CONG., Legislative Proposal for Treasury Authority to Purchase MORTGAGE-RELATED ASSETS (2008) http://www.moore.house.gov/ Resources/documents/TreasuryBailoutDraftBill.doc [hereinafter Treasury Draft Bill].

237. Id. $\S 6$. Though this would help if the crisis was larger than the initial number proposed-at the time there was speculation that it might be over a $\$ 1.5$ trillion crisis. See Joe Nocera, A Hail Mary Pass, Hoping to Find a Receiver in the End Zone, N.Y. Times, Sept. 20, 2008, at Cl.

238. Specifically, the proposed statute provided the following:

The Secretary is authorized to take such actions as the Secretary deems necessary to carry out the authorities in this Act, including, without limitation:

(1) appointing such employees as may be required to carry out the authorities in this Act and defining their duties;

(2) entering into contracts, including contracts for services authorized by section 3109 of title 5, United States Code, without regard to any other provision of law regarding public contracts;

(3) designating financial institutions as financial agents of the Government, and they shall perform all such reasonable duties related to this Act as financial agents of the Government as may be required of them;

(4) establishing vehicles that are authorized, subject to supervision by the Secretary, to purchase mortgage-related assets and issue obligations; and

(5) issuing such regulations and other guidance as may be necessary or appropriate to define terms or carry out the authorities of this Act.

Treasury Draft Bill, supra note 236.

239. Id. §5. 
using the $\$ 700$ billion. $^{240}$ Third, in enacting these provisions, the Secretary's draft directed his attention to two particular goals: the interests of "providing stability or preventing disruption to the financial markets or banking system; and ... protecting the taxpayer."241

Most controversially, Paulson's proposal did not provide for judicial review of anything his Department did; instead "[d]ecisions by the Secretary pursuant to the authority of this Act are non-reviewable and committed to agency discretion, and may not be reviewed by any court of law or any administrative agency." 242 By providing no review of Treasury's decisions, either by a court or any other part of the Executive Branch, it was not clear what sort of limits the suggested considerations for the Secretary's purchasing decisions would impose.

Generally, when Congress legislates in the economy, it can do as it wishes-even when that action would involve massive government expenditures with few procedural strings attached. Congress bailed out savings and loans before, ${ }^{243}$ and survived constitutional challenge then. ${ }^{244}$ The constraints on the sort of legislation represented by the Paulson bill only come from the Constitution, and, when legislation does not impinge on particular rights guaranteed by the Bill of Rights, the constitutional pitfalls are threefold, implicating the Due Process Clause, the nondelegation doctrine, and the Commerce Clause. Because these constitutional concerns arose in every version of the bailout bill, including the one eventually passed by Congress, we sketch the way that they apply to legislation here; our principal insight, however, is that when Congress acts, the nature of the authority game changes - the constraints on economic legislation are few, and lie mostly in disfavored provisions of constitutional law.

The Due Process Clause forbids deprivations of life, liberty, or property without "due process of law." 245 That famously undefined term has required centuries of judicial unpacking but, as currently interpreted, did not look like a serious restriction on the Paulson draft (or, indeed, any other variant of the bailout legislation). To be sure, the purchase of troubled assets threatened to deprive the asset holders of their property; the bailout, given Treasury's past practices, would be accompanied by a sub silentio threat that the government might pay pennies on the dollar for the troubled

240. Id. $\S 6$.

241. Id. $\S 4$.

242. Id. $\S 8$.

243. See, e.g., Federal Deposit Insurance Corporation, The S\&L Crisis: A ChronoBibliography, http://www.fdic.gov/bank/historical/s\&l/ (last visited Apr. 9, 2009).

244. See Donald F. Kettl, The Savings-and-Loan Bailout: The Mismatch Between the Headlines and the Issues, 24 POL. SCI. \& POL. 441 (1991).

245. U.S. CONST. amend. V. 
assets. But courts have never been willing to make constitutional cases out of the type of arms-length transactions contemplated by Paulson's asset purchase proposal, even in situations where the sellers to the government have little other option. ${ }^{246}$ Volunteers, in short, generally forfeit the limited rights that due process exercises over their sales to the government. ${ }^{247}$

Usually when Congress acts in the economy, it alludes to the Commerce Clause, which permits the federal government to legislate (and otherwise act) "to regulate Commerce ... among the several States."248 There was no such allusion in the Paulson proposal. ${ }^{249}$ But ever since Wickard $v$. Filburn, Congress has been permitted to devise administrative schemes that regulate the most local of transactions, like (in that case) the growth of wheat by farmers for personal consumption. ${ }^{250}$ Troubled mortgage-related assets, which tended to agglomerate pieces of many mortgages concluded in many different local jurisdictions, were unlikely to be interpreted differently, and, indeed, no one during the bailout debate suggested that the bill unconstitutionally expanded Congress's ability to regulate interstate commerce.

The constitutional question most troublingly presented by the Paulson draft-albeit less obviously by the congressional statutes that elaborated Treasury's responsibilities and that followed it-was whether the bill delegated an unconstitutionally undefined amount of power to Treasury. The nondelegation doctrine provides that statutes that do not provide an "intelligible principle" limiting broad authority delegated to the Executive Branch might unconstitutionally give the Executive the power to perform essentially legislative functions. ${ }^{25}$

246. See Jere D. McGaffey, Formation of the Partnership, in 1 PARTNERShIPS, LLCs, AND LLPS 51, 78 (2007).

247. A similar analysis would apply under the Takings Clause. Under the traditional Penn Central test, regulatory takings claims are only viable when the government frustrates "distinct" investment-backed expectations and where there is a substantial diminution in the value of the asset. See Penn Cen. Transp. Co. v. New York City, 438 U.S. 104 (1978). It is not clear that the shareholders in financial institutions could not expect dilution of their shares through equity injections, either from the government or from other shareholders; this sort of dilution is common in public corporations. Moreover, courts have looked for substantial diminutions in value directly attributable to the taking, which may be difficult to prove in light of the battering financial stocks were taking anyway and, except in the case of AIG, might be too high a barrier for an equity dilution claim to get off the ground. See, e.g., Concrete Pipe \& Prods. of California, Inc. v. Constr. Laborers Pension Trust, 508 U.S. 602, 645 (1993) (finding that a $46 \%$ diminution in value did not support a taking).

248. U.S. CONST. art. I, \& 8, cl. 3.

249. Although it did use the phrase "commercial mortgages." See Emergency Economic Stabilization Act of 2008, Pub. L. No. 110-343, \& 3, 122 Stat. 3766 (to be codified at 12 U.S.C. $\S 5202)$.

250. Wickard v. Filburn, 317 U.S. 111, 128-29 (1942).

251. See J.W. Hampton, Jr., \& Co. v. United States, 276 U.S. 394, 409 (1928) (concluding that an "intelligible principal" in the statute permitted the Customs Service to 
Nondelegation questions arise for any statute that awards responsibilities for administration to any agency, but the doctrine has only had one good year-1935, when two extraordinarily broad delegations from the New Deal Congress to the Roosevelt Administration were found to transgress the limits of the clause. ${ }^{252}$ The Paulson draft, expansive though it was, was probably no more likely to suffer from this particularly rare constitutional defect. The statute was focused on a particular topic, asset purchases, which alone suggested the existence of an intelligible principle. ${ }^{253}$ The draft also directed Treasury to protect the taxpayer as well as provide stability to the markets, which was also a sign that it was focused on particular goals. ${ }^{254}$

The possible nondelegation problem in the Paulson proposal laid in the fact that the bill did, in authorizing the bailout, permit the Secretary to run banks (or appoint the employees to do so), buy things, issue regulations, and so on. Broad though these powers were, they were not limited by the Paulson draft: "The Secretary is authorized to take such actions as the Secretary deems necessary to carry out the authorities in this Act, including, without limitation" sales, appointments, regulations, etc. ${ }^{255}$

It was that "without limitation" language-suggesting that the powers granted to Treasury were examples, rather than limited authorizations, that most raised the possibility of unconstitutionality. After all, unlimited powers to spend $\$ 700$ billion looks almost exactly like the powers that Congress, and not the Treasury Department, is supposed to exercise, and the nondelegation doctrine is premised on the idea that Congress cannot give away too many of its legislative powers. Had it been passed, the Paulson draft could, at least in regard to this provision, have been a fascinating test of the nondelegation doctrine.

However, Congress did not pass the Paulson bill word for word. It instead countered with a few draft bills offering the Treasury Secretary more limited authority. Of these, the so-called Dodd proposal exemplified the legislative response. That proposal added detail to the Paulson proposal and some possibly ceremonial restrictions on corporate governance but retained the basic concepts of the bailout-the $\$ 700$ billion, the administration by Treasury, and the broad flexibility the government would have to tailor its approach to events. The most important parts of the

revise tariff duties).

252. See Panama Ref. Co. v. Ryan, 293 U.S. 388 (1935); A.L.A. Schechter Poultry Corp. v. United States, 295 U.S. 495 (1935).

253. J.W. Hampton, Jr., \& Co., 276 U.S. at 409.

254. See Treasury Draft Bill, supra note 236 and accompanying text.

255. Emergency Economic Stabilization Act of 2008, Pub. L. No. 110-343, § 101, 122

Stat. 3767 (2008) (to be codified at 12 U.S.C. $\$ 5211$ ) (emphasis added). 
congressional counterproposal were those granting wider discretion to Treasury to purchase securities, thereby permitting equity injections as well as purchases of troubled-asset purchases, and those cabining Treasury's discretion through an oversight board, reporting by the Government Accountability Office, and, most notably, permitting judicial review. As the Senate explained, "We include[d] a provision to ensure the federal government gets warrants from companies that sell their bad assets to us." This was an optional proposal, to be sure, but one that gave Treasury the authority to implement the bailout through those injections. ${ }^{256}$

After an extremely short debate, and a series of front-page headlines, on September 29, the House of Representatives, led by an unlikely coalition of conservative Republicans opposed to government intervention in markets and liberal Democrats convinced that the bailout would not help the most downtrodden victims of the collapse of the housing bubble, voted down the Dodd proposal that amended the Paulson plan. ${ }^{257}$ The stock market cratered during the vote itself, ${ }^{258}$ much handwringing ensued, and three days later, the House revisited the bill, slightly amended and larded with a number of tax breaks and other member-specific benefits.

Both it and the Senate quickly passed the amended statute on October 4, which had grown from 3 pages in length to 451 pages in length in less than two weeks. Much of the additional verbiage was dedicated to the pork necessary to create a legislative majority in the House. But the bailout plan itself had expanded remarkably and Treasury had actually obtained in aggregate more authority to structure the program.

\section{B. The Bailout Statute}

The bailout statute was rooted in two programs that the Secretary could implement-one similar to the original troubled-asset purchases proposal, and the other a new, and relatively optional, insurance program. As for the initial program, the statute provided,

The Secretary is authorized to establish the Troubled Asset Relief Program (or "TARP") to purchase, and to make and fund commitments to purchase, troubled assets from any financial institution, on such terms and conditions as are determined by the Secretary, and in accordance with this Act and the policies and procedures developed and published by the Secretary. ${ }^{259}$

256. Summary of Dodd Legislative Changes to Treasury Proposal (Sept. 22, 2008), http://www.dodd.senate.gov/index.php?q=node/4567.

257. Carl Hulse \& David Herzenhorn, Defiant House Rejects Huge Bailout; Stocks Plunge; Next Step is Uncertain, N.Y. TIMES, Sept. 30, 2008, at Al.

258. The Dow Jones Index itself dropped almost 400 points in 5 minutes. Id.

259. Emergency Economic Stabilization Act of 2008, Pub. L. No. 110-343, § 101(a)(1), 122 Stat. 3767 (2008) (to be codified at 12 U.S.C. \$5211). 
Again, the grant of authority here was quite broad. The critical term troubled assets was defined in the congressional legislation to include not just "residential or commercial mortgages and any securities, obligations, or other instruments that are based on or related to such mortgages, that in each case was originated or issued on or before March 14, 2008, the purchase of which the Secretary determines promotes financial market stability" but also "any other financial instrument that the Secretary, after consultation with the Chairman of the Board of Governors of the Federal Reserve System, determines the purchase of which is necessary to promote financial market stability," which would also prove to be helpful language for the Secretary's pivot from asset purchases to equity injections. ${ }^{260}$

As for the insurance program, apparently added to the bill at the behest of Republicans uncomfortable with the more direct market intervention represented by asset purchases, it was a mandatory feature of the Secretary's plan. But the terms of offering were entirely at the Secretary's discretion:

The Secretary may develop guarantees of troubled assets and the associated premiums for such guarantees. Such guarantees and premiums may be determined by category or class of the troubled assets to be guaranteed.... Such guarantee may be on such terms and conditions as are determined by the Secretary, provided that such terms and conditions are consistent with the purposes of this Act. ${ }^{261}$

To implement these programs, the final iteration of the legislation granted Treasury substantial authority. The Secretary had the power to hire, fire, contract, issue regulations, "establish[] vehicles" to hold assets, and so on-Treasury's powers exercised pursuant to this section were only subject to judicial review for arbitrariness and capriciousness. ${ }^{262}$

Arbitrary and capricious review is the standard language of the Administrative Procedure Act (APA), but the complicated way it was finally added to the bailout statute is worth some analysis. Judicial review is the most powerful oversight tool Congress has, and in recent high profile statutes-such as the Military Commissions Act in the war on terror ${ }^{263}$-it elected not to require it. The policy reasons why are straightforward: judicial review is slow and ex post, judges are inexpert at complicated financial matters, and in the case of the savings and loan bailout it was adjudged by some to be ineffective. ${ }^{264}$ Requiring it had the potential to

260. Id. \& 3(9).

261. Id. $\S 102$.

262. Id. \& $101(\mathrm{c})(4)$

263. See generally Military Commissions Act of 2006, 10 U.S.C. $\S 948$ (2006).

264. Emergency Economic Stabilization Act of 2008, Pub. L. No. 110-343, §101(c)(4), 122 Stat. 3765,3767 (2008) (to be codified at 12 U.S.C. $\$ 5211$ ). 
change the entire character of the bailout from something done quickly by the Secretary to something done much more bureaucratically, with final determinations made over, potentially, a course of years of appeals, reversals, and remands. The chosen arbitrary and capricious standard is a favorable one for the government but not overwhelmingly so. In reported APA decisions in National Labor Relations Board and Environmental Protection Agency cases, the government wins somewhere between 55\% and $65 \%$ of the time, according to estimates from Cass Sunstein and Thomas Miles. ${ }^{265}$ Moreover, the judicial review was drafted confusingly. On the one hand, "Actions by the Secretary ... shall be held unlawful and set aside if found to be arbitrary, capricious, an abuse of discretion, or not in accordance with law." But, on the other hand, "No injunction or other form of equitable relief shall be issued against the Secretary for actions pursuant to section 101 [the power-granting section] ... other than to remedy a violation of the Constitution."266

Because arbitrary and capricious review essentially is equitable relief, it was unclear how, exactly, this sort of review would work. Indeed, the Supreme Court said exactly that in Doe v. Chao, where it referred to the "the general provisions for equitable relief within the Administrative Procedure Act" and cited a section of the same Title 5, Chapter 7 referenced in the bailout bill's judicial review provisions. ${ }^{267}$ And so the bill appeared to grant judicial review in one section, and then took it away, by taking away equitable relief, in the other section.

Perhaps attributable to the speed of the bailout's passage - the time from the Paulson proposal to the president's signature was less than a fortnightthe precise availability of the judicial review provisions of the bill were never clarified by Congress. ${ }^{268}$ The section-by-section notes prepared by the drafters said only that the section "[p]rovides standards for judicial review, including injunctive and other relief, to ensure that the actions of the Secretary are not arbitrary, capricious, or not in accordance with law., 269

265. Thomas J. Miles \& Cass R. Sunstein, The Real World of Arbitrariness Review, 75 U. CHI. L. REV. 761, 777 (2009).

266. Emergency Economic Stabilization Act of 2008, § 119(a)(1)-(2).

267. 540 U.S. 614,619 n.1 (2004). Laurence Tribe has characterized these provisions of the APA as equitable. See Laurence H. Tribe, Death by a Thousand Cuts: Constitutional Wrongs Without Remedies After Wilkie v. Robbins, CATO SuPREME CT. REV. 23, 46 n.88 (discussing 5 U.S.C. $\$ 706$ ).

268. Rumors of the bailout appeared on September 19, and the plan finally passed on October 3. See Bush Praises Senate Passage of Bailout, WMUR RADio, Oct. 2, 2008, http://www.wmur.com/news/17604991/detail.html\#-.

269. H. COMm. ON Fin. Servs., 111 th Cong., Section-By-Section Analysis of the LEGISLATION (2009), http://www.financialservices.house.gov/essa/final_bill_section-bysection.pdf. 
The other oversight mechanisms added by Congress to Paulson's initial, almost wholly unsupervised draft were standard but numerous-they included an Inspector General, regular evaluation by the Government Accountability Office, an oversight board, and frequent congressional reporting. ${ }^{270}$ As for the funding, the $\$ 700$ billion was approved, but in tranches, with $\$ 250$ billion available immediately and an additional $\$ 100$ billion released upon the Secretary's certification that more funds would be needed. ${ }^{271}$ The final $\$ 350$ billion was not given to the Secretary immediately. However, its issuance was all but guaranteed; it would only be denied Treasury if there was a fast-tracked congressional joint resolution of disapproval before its disbursal. ${ }^{272}$

The final statute contained a great deal more direction for Treasury than did the initial draft, but the direction was not very specific. For example, the Secretary was told to consult with various agencies (a weak constraint), to issue regulations (though those could come after the bailout began), and instructed that he "shall take such steps as may be necessary to prevent "unjust enrichment," "which is specified as meaning the Secretary could not pay more for the asset than the financial institution did when it bought it. $^{273}$ The statute also required that the Secretary set conflict-of-interest regulations. ${ }^{274}$

Few observers had targeted excessive executive compensation as one of the causes of the crisis, but it had played a role in the political campaigns of successful Democratic candidates who would be voting on the legislation, and some powerful constituencies of the party found it to be appealing. ${ }^{275}$ Legislative efforts to do something about executive compensation in the United States-famously, the highest in the world--found, in the crisis, a potential outlet for realization. Limits on executive compensation, clawbacks, and golden parachute bans, controversial favorites of some corporate scholars, ${ }^{276}$ appeared in the bill, but in a way that gave the Secretary substantial authority to define how they would be

270. Emergency Economic Stabilization Act of 2008, Pub. L. No. 110-343, §§ 104, 105, $121,125,122$ Stat. $3770,3770-71,3788,3791$ (2008) (to be codified at 12 U.S.C. $\$ \S 5214$ $15,5231,5233)$.

271. Id. § 115 .

272. Id.

273. Id. $\S 101(\mathrm{e})$ (emphases added).

274. Id. $\S 108(\mathrm{a})$.

275. Susan Lorde Martin, Executive Compensation: Reining in Runaway AbusesAgain, 41 U.S.F. L. REV. 147, 147 (2006) ("Every ten years or so, the problem of excessive executive compensation draws public attention, leading to some political action.").

276. See generally LuCIAN BebChuK \& Jesse Fried, PAy Without Performance: The Unfulfilled Promise of EXeCutive Compensation (2004). See also Lucian Bebchuk \& Yaniv Grinstein, The Growth of Executive Pay, 21 Ox. REv. ECON. POL. 283 (2005). 
implemented. ${ }^{277}$ In cases where

the Secretary receives a meaningful equity or debt position in the financial institution ..., the Secretary shall require ... limits on compensation that exclude incentives for senior executive officers of a financial institution to take unnecessary and excessive risks ... ; a provision for the recovery by the financial institution of any bonus or incentive compensation paid to a senior executive officer based on statements of earnings, gains, or other criteria that are later proven to be materially inaccurate; and a prohibition on the financial institution making any golden parachute payment to its senior executive officer during the period that the Secretary holds an equity or debt position in the financial institution. ${ }^{278}$

The three executive compensation limitations imposed by Congress were imposed with rather different language. The furthest reaching of the provisions - the compensation limitation - was created with terms entirely up to the Secretary to define. The retroactive clawback provision for previously paid compensation also turned, essentially, on the details the Secretary chose to impose. But the golden parachute provision was straightforwardly prohibitory.

Treasury, in short, had the flexibility to define the extent of the nonparachute terms of the executive compensation provisions as it wished. As Treasury never before regulated executive pay, the grant of authority was theoretically dramatic, but in practice unlikely to amount to a substantively meaningful limitation on American executive compensation. This calculus would later change when Congress enacted further restrictions in the $\$ 787$ billion stimulus bill, the American Recovery and Reinvestment Act of 2009. ${ }^{279}$ The provisions were inserted in the bill at the behest of Senator Dodd and opposed by the Obama Administration. As passed these provisions further limited compensation and purported to limit incentive compensation for the five most senior executive officers and twenty highest paid executives at companies receiving more than $\$ 500$ million in TARP funds. ${ }^{280}$

Moreover, some of the oversight mechanisms, though not overly onerous in what they could require Treasury to do, raised their own legal concerns. The Oversight Board, for example, was comprised of the Federal Reserve Chair, the Treasury Secretary, the Director of the Federal Housing Finance Agency (FHFA), the Chairman of the SEC, and the Secretary of

277. Emergency Economic Stabilization Act of 2008, Pub. L. No. 110-343, § 111,122 Stat. 3776, 3776-77 (2008) (to be codified at 12 U.S.C. $\$ 5221$ ).

278. Id.

279. American Recovery and Reinvestment Act of 2009, Pub. L. No. 111-5, 123 Stat. $115,516-20$ (2009).

280. Id. § 7001; see also Edmund L. Andrews \& Eric Dash, Stimulus Plan Places Tightens Reins on Wall St. Pay, N.Y. TIMES, Feb. 14, 2009, at A1. 
Housing and Urban Development. ${ }^{281}$ Three of these five officials-the Federal Reserve chair, the SEC chair, and the director of FHFA-chaired so-called independent agencies. Independent agency chairs may only be fired for cause, and the prospect of being unable to remove overseers limits the President's ability to oversee the overseers, which is not without constitutional moment, ever since Myers $v$. United States, which announced the theory of the unitary executive and awarded the president relatively broad removal powers. ${ }^{282}$

However, the Oversight Board was hardly charged with notable responsibilities; it was meant to "review[] the exercise of authority under a program developed in accordance with this Act, including [] policies implemented by the Secretary," and the "effect of such actions in assisting American families in preserving home ownership, stabilizing financial markets, and protecting taxpayers." But the tangible results of this review would be to make "recommendations, as appropriate, to the Secretary" and "report[] any suspected fraud." 283

Accordingly, although the composition of the Oversight Board might be interesting to administrative law scholars, it is unlikely that its unconventional structure will result in a judicial setback for the bailout because it will be difficult to pinpoint anything that the Board will have done that will injure anyone, and therefore it may be difficult to establish standing.

The bailout statute represented a dramatic expansion of the government powers to enter the financial markets, but it also represented a massive grant of flexibility to the Treasury Department, accompanied by hundreds of billions of authorized dollars. That the authorization was unprecedented is perhaps obvious. But by creating a vehicle for Treasury to purchase distressed assets and pairing the vehicle with substantial flexibility, it gave the Department the authority to explore a variety of alternative approaches to resolve the crisis. In short, although the bailout statute appeared to contemplate creating a government market participant, it did not forbid the government from returning to the ad hoc approach it had taken earlier and doing deals-that is, taking equity-with the financial institutions most troubled by the credit crisis. As would be quickly seen, Congress had taken Paulson's one-shot mortgage-related deal and given him a machine gun available for multiple dealmakings.

281. Emergency Economic Stabilization Act of 2008, Pub. L. No. 110-343, § 104, 122 Stat. $3766(2008)$ (to be codified at 12 U.S.C. $\$ 5214$ ).

282. 272 U.S. 52, 176 (1926).

283. Emergency Economic Stabilization Act of 2008, Pub. L. No. 110-343, § 104(a)(2)(3), 122 Stat. 3770 (2008) (to be codified at 12 U.S.C. $\S 5214$ ). 


\section{The Commercial Paper Program}

Even as the legislative response to the crisis produced a bill that the government began to gear up to implement, the Federal Reserve found it difficult to give up action by regulation through its very flexible interpretation of $\S 13$ of the Federal Reserve Act. Still apparently worried about the illiquid short-term credit markets-the markets that were supposed to be the most liquid of all—and the limited immediate success of the money market insurance initiative of the Treasury Department, the Federal Reserve announced its own foray into commercial paper, the shortterm bonds issued by financial institutions like Lehman and large companies like General Electric and, because of their less-than-ninety-day duration, exempted from regulation by the SEC. ${ }^{284}$

On October 6, the Federal Reserve announced that it would purchase commercial paper directly from issuers-a substantial commitment, given that the commercial paper market was worth $\$ 1.6$ trillion at the time. ${ }^{285}$ The Federal Reserve apparently hoped that a direct commercial paper purchase program would offer direct relief to big institutions that needed to be sure of the availability of short-term financing but were still unable to find money market funds or other willing purchasers. It dubbed its effort the "Commercial Paper Funding Facility."

Once again, the governance issues were striking. Congress did not okay the foray into commercial paper, and no one even mentioned commercial paper during congressional testimony during the bailout legislation debate. Moreover, creating the program moved the Federal Reserve into a form of business oversight because the agency would be getting either security or money in exchange for its paper from corporations. ${ }^{287}$

None of this appeared to trouble the central bank. The Federal Reserve created the commercial paper facility by emergency regulation and a quick, albeit supermajority, vote. ${ }^{288}$ This is not to suggest that the Federal

284. Jon Hilsenrath \& Prabha Natarajan, Federal Reserve to Buy Commercial Paper, SMART MONEY, Oct. 7, 2008, http://www.smartmoney.com/breakingnews/smw/?story $=20081007094827$.

285. For the number, see John Carney, Commercial Paper: Neither a Borrower nor a Lender Be, Clusterstock, Oct. 6, 2008, http://www.clusterstock.com/2008/10/ commercial-paper-neither-a-borrower-nor-a-lender-be. For background, see Edmund L. Andrews \& Michael M. Grynbaum, Central Bank Would Buy Companies' Unsecured Debt, N.Y. TIMES, Oct. 7, 2008, at A1.

286. BD. OF Governors of the Fed. Reserve Sys., Report Pursuant to Section 129 of THE EMERgenCy ECON. Stabilization ACt of 2008: Commercial PaPer Funding

FACILITY (2008), http://www.federalreserve.gov/monetarypolicy/files/129mmiff.pdf.

287. Stephen Labaton, S.E.C. Concedes Oversight Flaws Fueled Collapse, N.Y. TimES, Sept. 27, 2008, at Al.

288. Craig Torres, Fed to Purchase U.S. Commercial Paper to Ease Crunch, BLOOMBERG.COM, Oct. 
Reserve was engaged in a headlong rush to give Wall Street and big corporations whatever they wanted; the government action, though obviously a subsidy of sorts, was no giveaway. The Federal Reserve did not buy the paper at a big discount. It used a "spread over the 3-month overnight index swap (CIS) rate," mooting one hundred basis points as a target for the paper, in an effort to mimic what would happen in the commercial paper market under more-normal market conditions. ${ }^{289}$ It required some security (although it defined that security quite flexibly), such as assets, an upfront fee, or a guarantee from someone else. And it organized the facility in a somewhat nonintuitive manner; it created a special purpose vehicle to which it will loan money at the federal funds rate. "Draws on the facility will be on an overnight basis," will be "with full recourse to the S[pecial] P[urpose] V[ehicle] and will be secured by all the assets of the SPV.,"290

Finally, the arrangement was designed to last for a short period-six months-although, of course, given its broad interpretation of its $\S 13$ powers, the Federal Reserve could renew the facility as it wished. We discuss the Federal Reserve's actions with regard to commercial paper partly to be comprehensive, but partly also as a reminder that the bailout statute was one of a number of approaches that the government was pursuing during the crisis. The Federal Reserve in particular continued to resourcefully resort to its $\S 13$ powers to try other ways of helping to ease the credit squeeze, and, of course, during this period it was exploring a variety of macroeconomic approaches including coordinated injections of liquidity into the money supply and the like. ${ }^{291}$

\section{THE AFTERMATH OF GOVERNMENT ACTION}

We save much of the consideration of the implementation of the bailout-a work in progress, with effects that will be felt for years-for the future. But one aspect of the immediate aftermath of the bailout bill's passage is worth analysis. As soon as Treasury received its authority to purchase troubled assets, it decided not to do so. Following the lead of the United Kingdom and other European countries, Treasury instead decided to take equity in struggling banks rather than taking the assets off their hands.

http://www.bloomberg.com/apps/news?pid=20601087\&sid=aAyx4qPsKSZk\&refer=home.

289. BD. OF GOVERNORS OF THE FED. RESERVE SYS., supra note 286.

290. Id. at 2-3. Why the fancy footwork? As John Carney has observed, "This neatly gets around any issue about whether the Fed should be in the business of making unsecured loans since it won't be lending directly to commercial paper issuers." See John Carney, Another Huge Bailout: Fed's New Commercial Paper Fund, Clusterstock, Oct. 7, 2008, http://www.clusterstock.com/2008/10/fed-announces-commercial-paper-bailout-fund.

291. See Treasury Draft Bill, supra note 236 and accompanying text. 
The dealmaking precedent formed by the government's actions before the bailout, in short, proved hard to break.

The Treasury Department, after obtaining hard-won legislation, pivoted from the asset purchase plan mooted before Congress to an equity purchase program, and in the end decided to make equity injections a central part of any rescue. ${ }^{292}$ Why did Treasury turn from the plan it had asked Congress to approve to an entirely different approach? The markets did not respond well to the possibility of government purchases of hard-to-value assets. After a few days of stock market declines, continued credit market turmoil, and an increasing internationalization of the crisis as banks in Europe began to find their own balance sheets in crisis, observers began to call for the injection of equity into banks, with the idea roughly being that providing banks with the capital on hand to meet their obligations that would not be met if they had to sell their unsaleable assets would be better than taking the unsaleable assets off their hands. ${ }^{293}$

The European proposal was accompanied by a more comprehensive government intervention into the markets, though this comprehensiveness was partly a function of the fact that European depositors were less protected than their American counterparts to begin with. The European governments, in addition to announcing that they would guarantee the safety of the deposits in banks - thus providing the insurance on deposits that already existed in the United States via the FDIC - suggested that they were inclined to inject capital into the banks themselves. In addition, a number of economists, of all ideological stripes, urged a partial nationalization of the banks as a more efficient way to unfreeze the credit markets. ${ }^{294}$

The result was something that looked like a global rejection of the value of the American asset purchase plan. After Great Britain announced that it would bail out its banks by taking equity in them, other European countries began to announce similar approaches. ${ }^{295}$ Meanwhile, the troubled-asset

292. See Press Release, U.S. Dep't of the Treasury, Secretary Geithner Introduces Financial Stability Plan (Feb. 10, 2009), http://www.financialstability.gov/docs/factsheet.pdf. The Treasury Department would later return to attempt to implement a troubledasset purchase program in partnership with private entities. See Press Release, U.S. Department of the Treasury, Joint Statement by Secretary of the Treasury Timothy F. Geithner, Chairman of the Board of Governors of the Federal Reserve System Ben S. Bernake, and Chairman of the Federal Deposit Insurance Corporation Sheila Bair (July 8, 2009), http://www.financialstability.gov/latest/tg_07082009.html.

293. See Greg Mankiw's Blog, http://gregmankiw.blogspot.com/2008/10/how-torecapitalize-financial-system.html (Oct. 8, 2008) ("There is broad agreement among economists that what the financial system needs right now is not only an injection of liquidity but also a recapitalization.").

294. See id.

295. See Paul Krugman, Op-Ed., Gordon Does Good, N.Y. TIMEs, Oct. 13, 2008, at A29 
purchase plan contained a number of logistical complexities, running from valuation to eligibility, and so on, which suggested that it would be difficult to implement quickly. The notable result was that the Americans deferred to the global approach. First, Treasury announced that it would consider, like Britain, taking equity in banks. ${ }^{296}$ It paired this announcement with the FDIC deposit guarantee increase to $\$ 250,000$ and the first Federal Reserve commercial paper initiative. ${ }^{297}$ Moreover, Treasury indicated that it believed it had the authority to turn away from asset purchases, even though it had not sought this authority in its initial bailout request. As Treasury Secretary Paulson said on October 8,

[T] he EESA adds broad, flexible authorities for Treasury to buy or insure troubled assets, provide guarantees, and inject capital. We will use all of the tools we've been given to maximum effectiveness, including strengthening the capitalization of financial institutions of every size. 298 We will design programs that encourage healthy institutions to participate. ${ }^{298}$

The "strengthening . . capital[]" phrase - or partly nationalizing banks, in essence-was not what the initial bailout appeared to contemplate; it was, after all, both pitched and passed as a "Troubled Assets Relief Program." Based on the debate that happened when the statute was passed, observers could be excused for thinking that the assets at issue were the mortgage-backed securities that the financial institutions could not sell.

But the relevant grant of authority provided more; it authorized the Secretary to

make and fund commitments to purchase . . . troubled assets from any financial institution, on such terms and conditions as are determined by the Secretary, and in accordance with this Act and the policies and procedures developed and published by the Secretary...[including] establishing vehicles that are authorized, subject to supervision by the Secretary, to purchase, hold, and sell troubled assets and issue obligations.

Moreover, "troubled assets" were defined, in relevant part, as

any other financial instrument that the Secretary, after consultation with the Chairman of the Board of Governors of the Federal Reserve System,

(noting that at a specially convened European summit, the major economies of Europe agreed to generally follow Great Britain's prescriptive approach to the banking crisis).

296. Edmund L. Andrews \& Mark Landler, U.S. May Take Ownership Stake in Banks to Ease Credit Crisis, N.Y. TIMES, Oct. 9, 2008, at A1.

297. See Saskia Scholtes, FDIC Expands Its Guarantees as Confidence Flags, FIN. TiMES, Oct. 15, 2008, at 9 (on FDIC limits); Press Release, Fed. Reserve Bd. (Sept. 19, 2008), http://www.federalreserve.gov/newsevents/press/monetary/20080919c.htm (on commercial paper).

298. See Press Release, U.S. Dep't of the Treasury, Statement by Sec'y Henry M. Paulson, Jr. on Fin. Markets Update (Oct. 8, 2008), http://www.treas.gov/press/releases/hp1 189.htm (emphasis added).

299. Emergency Economic Stabilization Act of 2008, Pub. L. No. 110-343, §101, 122 Stat. 3767 (2008) (to be codified at 12 U.S.C. $\$ 5211$ ). 
determines the purchase of which is necessary to promote financial market stability, but only upon transmittal of such determination, in writing, to the appropriate committees of Congress. ${ }^{300}$

The result was a rapid change in the way Treasury decided to use its $\$ 700$ billion authorization, and one more consistent with the emerging global approach. ${ }^{301}$ Over a busy weekend on October 19, Treasury announced that it would inject a quick $\$ 125$ billion into the nation's largest banks, and that it had cajoled them all into accepting the money as their duty as regulated entities. ${ }^{302}$

As a legal matter, Treasury announced that it interpreted a detail added to the bailout bill to give Treasury the authority to change its approach so quickly:

The law gives the Treasury Secretary broad and flexible authority to purchase and insure mortgage assets, and to purchase any other financial instrument that the Secretary, in consultation with the Federal Reserve Chairman, deems necessary to stabilize our financial markets-including equity securities. Treasury worked hard with Congress to build in this flexibility because the one constant throughout the credit crisis has been its unpredictability. ${ }^{303}$

The terms of the capital injections would grant the government warrants to purchase common stock and outright grants of preferred stock, which was pari passu to existing preferred shares in the capital structure of the banks. The scheme certainly had the effect of diluting the equity of the existing shareholders of the banks, but it contained provisions encouraging relatively quick repayment-the government's initial dividend rate was to be $5 \%$, but that rate would increase to $9 \%$ after five years. The warrants would also be reduced both in size and in value if the financial institution that accepted the equity would repurchase the preferred shares or the warrants quickly. ${ }^{304}$

In fact, on November 12, 2008, Secretary Paulson announced that the government was completely abandoning the idea of TARP and instead using the entirety of its first $\$ 250$ billion for injections in troubled financial

300. Id. $\S 3$ (emphases added).

301. See Krugman, supra note 295.

302. See Mark Landler, U.S. Investing \$250 Billion to Bolster Bank Industry; Dow Surges 936 Points, N.Y. TimES, Oct. 14, 2008, at A1.

303. See Press Release, U.S. Dep't of the Treasury, Interim Assistant Sec'y for Financial Stability Neel Kashkari Remarks Before the Inst. of Int'l Bankers (Oct. 13, 2008), http://www.treas.gov/press/releases/hp1 199.htm.

304. The executive compensation limitations on those banks that accepted the equity would also, of course, encourage their quick repayment of the government's investment. In addition, the Federal Reserve later amended its regulations to allow these preferred share injections to be treated as Tier 1 capital. See Press Release, Bd. of Governors of the Fed. Reserve Syst. (Oct. 16, 2008), http://www.federalreserve.gov/newsevents/press/bcreg/20081016b.htm. 
institutions. ${ }^{305}$ And using this authority broadly, Secretary Paulson also announced that the EESA capital injection program would be extended to nonbank financial institutions that provide credit, such as credit card providers. ${ }^{306}$ Treasury also announced that it would try to distribute the first $\$ 250$ billion tranche quickly. ${ }^{307}$

In this gap period between November 2008 and January 20, 2009, the date the Obama Administration took office, the Treasury Department continued its practice of regulation by deal to increasing public and congressional criticism. In particular, it devoted large resources to two large banks, providing more dealmaking regulation, where control remained in the hands of the operators of the enterprise, but investment remained the government's role. Consider Citigroup: an inefficient behemoth in the best of times, it appeared to be coming apart amidst market fears for its ability to survive in late November. ${ }^{308}$

Over the weekend of November 22, the FDIC, Federal Reserve, and Treasury Department stepped in to stabilize Citigroup. The Treasury, Federal Reserve, and FDIC collectively agreed to fund the off-balancesheet purchase of approximately $\$ 306$ billion of Citigroup's troubled assets. $^{309}$ This appeared to be a variation on the bad bank model that Lehman had proposed and was modeled on the initial, failed WachoviaCitigroup deal. Treasury agreed to take the first $\$ 5$ billion of losses on these assets, the FDIC the next $\$ 10$ billion, and the Federal Reserve the remainder. The government guarantee was subject to a loss-sharing agreement wherein $10 \%$ of the losses were to be borne by Citigroup.

In addition, Citigroup agreed to guarantee the first $\$ 29$ billion in losses. In exchange for this guarantee, the government received $\$ 7$ billion in preferred shares in Citigroup and invested another $\$ 20$ billion in exchange for a further issuance of preferred shares. But unlike other beneficiaries under the EESA, this preferred stock barred the paying of dividends by Citigroup above one cent per share for three years and yielded a higher interest rate of $8 \%$ from their issuance. The government slotted Citigroup in the middle bailout category between the stable financial banks and the

305. See Press Release, U.S. Dep't of the Treasury, Remarks by Sec'y Henry M. Paulson, Jr. on Fin. Rescue Package \& Econ. Update (Nov. 12, 2008), http://www.treas.gov/press/releases/hp1265.htm.

306. Id.

307. See Press Release, U.S. Dep't of the Treasury, Statement by Sec'y Henry M. Paulson, Jr. on Capital Purchase Program (Oct 20, 2008), http://www.treas.gov/press/releases/hp1223.htm.

308. See Eric Dash \& Louise Story, Citigroup Leads the Way as Financial Stocks Go into Freefall, N.Y. TIMES, Nov. 21, 2008, at B1.

309. Citigroup Inc., Current Report (Form 8-K) (Nov. 26, 2008), http://idea.sec.gov/Archives/edgar/data/831001/000095012308016585/y72849e8vk.htm. 
systemically failing ones like AIG. Finally, Treasury received $\$ 2.7$ billion in warrants to purchase common shares of Citigroup. These warrants were priced beneficially to Citigroup on a twenty-day moving average, so the strike price was $\$ 10.61$ per share, a price significantly out of the money compared to Citigroup's trading price the Friday before the deal announcement of $\$ 3.78$. Treasury only took $10 \%$ of the total value of the preferred in warrants, as opposed to $15 \%$ in prior EESA transactions. The reason likely was to keep the government's ownership interest below a certain threshold. On January 2, 2009, after announcing the Citigroup bailout, the government created the Targeted Investment Program-a new program under the EESA encompassing bailouts like Citigroup that were investments in neither systemically failing nor stable financial institutions. ${ }^{310}$

On February 27, Citigroup announced that its federal bailout would again be reworked. This time Citigroup agreed to offer to exchange common stock for up to $\$ 27.5$ billion of Citigroup's preferred shares. The federal government agreed to exchange up to $\$ 25$ billion of its preferred shares under this offer. ${ }^{311}$ The offer closed on July 24, 2009, with the government now owning $34 \%$ of Citigroup. ${ }^{312}$

The Citigroup model and this new program would be used in the Bank of America bailout in early January 2009. At the time Bank of America claimed that its need for funds was related to a massive $\$ 15.3$ billion loss at the newly acquired Merrill Lynch, a fact that Bank of America apparently knew of in mid-December but did not disclose at the time. ${ }^{313}$ This nondisclosure would become quite controversial as Bank of America CEO Ken Lewis would later claim that this information was not disclosed at the request of the federal government. Nonetheless, in December Bank of America informed the government that it was thinking of invoking the material adverse change clause in its acquisition agreement for Merrill Lynch to attempt to terminate its obligation to acquire the bank. The full details of the government's conversations with Bank of America are still unknown, but apparently the government claimed that Bank of America lacked a legal basis to make this allegation and that, in order to preserve

310. See Press Release, U.S. Dep't of the Treasury, Treasury Releases Guidelines for Targeted Investment Program (Jan. 2, 2009), http://www.ustreas.gov/press/releases/hp1338.htm.

311. Citigroup Inc., Current Report (Form 8-K) (Feb. 27, 2009), http://www.sec.gov/Archives/edgar/data/831001/000095010309000421/dp12698_8k.htm.

312. See Associated Press, Citigroup Completes \$58 Billion Stock Swap, ForBES.COM, July 27, 2009, http://www.forbes.com/feeds/ap/2009/07/27/ap6702311.html.

313. See Bank of America Corp., Current Report (Form 8-K), exhibit 99.1 (Press Release) (Jan 16, 2009), http://idea.sec.gov/Archives/edgar/ data/70858/000119312509007109/0001193125-09-007109-index.idea.htm. 
market stability, it preferred that Bank of America complete the acquisition. The government also apparently threatened to remove Mr. Lewis from his position if he invoked the material adverse change clause and offered a carrot of more financial assistance. ${ }^{314}$ The Bank of America bailout was finalized on January 15, 2009, bringing the total government investment in Bank of America to $\$ 45$ billion. ${ }^{315}$

Meanwhile, public criticism increased, claiming that the government's program was ineffective, opaque, haphazard, and overly beneficial to financial institutions. ${ }^{316}$ On January 11, 2009, the Congressional Oversight Panel for Economic Stabilization released a scathing report on the implementation of the EESA asserting that "[t]here has been much public confusion over the purpose of the TARP, and whether it has had any effect on the credit markets, helped in price discovery for frozen assets, or increased lending." 317 That same day Congressman Barney Frank submitted the TARP Reform and Accountability Act of 2009 to Congress with the purpose of "reform[ing] the Troubled Asset Relief Program of the Secretary of the Treasury and ensur[ing] accountability under such Program." 318 In the wake of these criticisms, the Obama Administration publicly proposed a return to the initial troubled-asset purchase program proposed by Treasury Secretary Paulson. This was a startling turn of events, and we believe it highlighted the failure of the government to publicly put forward a more cohesive plan.

\section{ANALYSIS AND CONCLUSION}

We conclude with a reflection on the consistent patterns of financial crises, and then return to some of the lessons we take from the government's response to this most recent one and their implications for the scholarly literature. We think that, as a study of deals, the government did save the financial system but did not achieve its full objectivefinancial stabilization-through its dealmaking. But this judgment will need to be reevaluated with the benefit of time and further research. We consider other implications of the government's response for deal and regulation theory. For regulation, we conclude that the crisis marks a rejection of federalism, a triumph of agencies over courts, an example of

314. See Liz Rappaport, Lewis Testifies U.S. Urged Silence on Deal, WALl ST. J., Apr. 23, 2009, at Al.

315. See Bank of America Corp., Current Report (Form 8-K) (Jan. 22, 2009), http://idea.sec.gov/Archives/edgar/data/70858/000119312509009753/d8k.htm.

316. See Floyd Norris, Another Crisis, Another Guarantee, N.Y. Times, Nov. 25, 2008, at $\mathrm{B} 1$.

317. See CONG. Oversight PANEL, supra note 15 , at 8.

318. TARP Reform and Accountability Act of 2009, H.R. 384, 111 th Cong. (2009). 
the nuanced effects law can have on emergency, and a surprising foray into corporatist governance. For deals, we conclude that the crisis illustrates a way out of the path-dependence story that characterizes much deals scholarship, a surprising embrace by the government of a venture capital model of deals where a private equity model might have made more sense.

We agree with Charles Kindleberger that financial crises have a timeline. ${ }^{319}$ Government responses to crises have their own pattern as well. The response often begins with the scramble of governments to keep up with fast-paced and deleterious market events, leading to an initial, ad hoc phase in government action, where emergencies are responded to with emergency-style rules and emergency-style process. ${ }^{320}$ In sufficiently serious crises, the next phase may be a legislative one-beginning with outraged congressional hearings and then new legislative authority. At about this time, implementation of the criminal investigations hit their stride, leading to the ex post punishment-often quite severe punishmentof a few symbols of the crisis, such as high-ranking CEOs and some unfortunate exemplars of excess. ${ }^{321}$ Finally, there is reform; either reform forgone in favor of blue-ribbon commissions and minor regulatory reorganization, or reform embraced by new legislation and a restructuring of the financial regulatory system.

If this pattern is relatively robust, it is hardly a template for what to do. Instead, the felt-and, we suspect, correct-lesson from prior panics is that the key to stemming a downfall is leadership and the confidence it provides investors. The goal is to ameliorate the short-term disjunctions in capital markets as investors-due to information asymmetry and outright feartransfer assets in a desperate search for safety. In The Panic of 1907, Robert Bruner and Sean Carr detail the role of J.P. Morgan Jr. in leading the New York markets toward stability. ${ }^{322}$ That crisis, like this one, began with macroeconomic turbulence, came to a head with the fall of a bank (although not one that collapsed into an orchestrated sale, as did Bear Stearns), and subsided in a flurry of dealmaking and asset guarantees led by Mr. Morgan rather than by the Treasury Department. ${ }^{323}$ In a more recent

319. See Charles P. Kindleberger \& Robert Aliber, Manias, PANics, AND Crashes: A History OF FINANCIAL CRISES 24-25 (5th ed. 2005).

320. See Oversight of Implementation of the Emergency Economic Stabilization Act of 2008 and of Government Lending and Insurance Facilities: Impact on the Economy and Credit Availability: Hearing Before the H. Comm. on Financial Services, 110th Cong. (2008) (statement by Henry M. Paulson Jr., Secretary, United States Department of the Treasury), http://www.treasury.gov/press/releases/hp 1279.htm.

321. We draw no definitive conclusions about the usefulness of the criminal response here. Nonetheless, it is typically, and apparently is in this case, a part of the government's postbailout tool kit that it deems important.

322. See generally RoBert F. BRUNER \& SEAN D. CARR, The PANIC OF 1907 (2007).

323. Id. 
U.S. financial crisis, albeit a smaller one, the collapse of Long-Term Capital Management, the New York Federal Reserve played a crucial leadership role organizing a private-sector solution. ${ }^{324}$ And that leadership often turns on dealmaking. In its initial response, the government, or the primary actor in the case of J.P. Morgan, is a dealmaker, deciding which entities live or die, structuring transactions to save the market, and attempting to restore stability through dramatic transactions.

The government's experience during this financial crisis was consistent with some prior ones in this way, though it demonstrated the limits of such a response-and perhaps the difficulties faced by the government in this crisis suggest that it embraced the dealmaking role creatively but imperfectly. The government drove hard, creative bargains, but each deal did not restore the confidence the government thought it would. Instead, in today's complex, interconnected world, each deal seemingly brought on more problems and unintended consequences as it created a world where free riding on government action became the norm. Moreover, the government's so-called guiding principle of moral hazard, even to the extent it was applied with integrity-which it was not-seemed to be out of sorts in such a momentous financial crisis. The government nonetheless resisted a comprehensive solution and continued to structure and initiate deals reactively. It did so until it became clear that this path was no longer appropriate. In short, we view the government's turn to the EESA as a signal that it felt bound by legal restraints and ultimately could not push past them until it acted to adopt a more comprehensive, confidencebuilding program designed to alleviate the lost confidence, fear, and information asymmetry in the markets. It was at this point that the principle of moral hazard was abandoned for more practical approaches.

But then it structured the biggest deal of all-the $\$ 125$ billion TARP injection into the nine largest U.S. financial institutions - acting in a similar manner but with a more comprehensive tone. This big deal, mirrored on the pattern of smaller ones, did make a difference. But the bailout deal underscored the lack of a holistic approach to the crisis. Ultimately, the legislative bailout marked the end of the beginning of the crisis, but not the end of the government's action in the crisis.

As to all of this, the bailout is now being administered and implemented - this will constitute the middle stage of the crisis. Once the crisis is over, it will be worth reflecting further on what went wrong with the system of financial regulation and how it might be reformed. But work on what should come next, and on how this massive new intervention in the economy would be implemented, precisely, we save for future research—it

324. For an overview, see Roger LOWENSTEIN, WhEN GENIUS FAILED (2000). 
is too soon to know how the only partly implemented bailout scheme will work. But in this study we have attempted to lay the framework for that study and also a foundation for government action in future crises.

Although events like the financial crisis are momentous enough for analysis in their own right, it is worth noting some of the implications of the bailout for scholarship, particularly the scholarship of where decisionmaking power lies, and how deals are made.

A Triumph of Agencies over Courts. In light of the crisis, some public law scholars will feel better about their preferred interpretations on the locus of decisionmaking than others. For example, those writers less inclined to focus on the centrality of the courts in the administrative state look like they were on to something. Amid the drama of the crisis, there has not been a single judicial decision of note, which is consistent with a trend in administrative law. Much of what agencies do now, such as regulation by best practice and international harmonization, is regulation exempt from judicial review. ${ }^{325}$ Ever since the founding of the Office of Management and the Budget, it has appeared that legal interpretation within the Executive Branch itself is a critical component of government decisionmaking - so much so that some scholars have characterized the modern era as one of "presidential administration." 326 The bailout, by essentially cutting courts out of the analysis, is largely consistent with this analysis of the focus of government actions. The difference is that the President has had apparently little to do with the government's administration of the crisis, which has been coordinated by a cabinet secretary and the head of a so-called independent agency-one that lies at least partly outside the Executive Branch. ${ }^{327}$

325. For an overview of best practices rulemaking, see David Zaring, Best Practices, 81 N.Y.U. L. REV. 294 (2006).

326. See, e.g., Elena Kagan, Presidential Administration, 114 HARv. L. REv. 2245, 2246 (2001). As a descriptive matter, Presidentialists tend to locate the (to their minds) worth enhancements of the President's role in the domestic administrative state in a series of executive orders. President Reagan's 1981 Executive Order on regulatory review, No. 12,291 , required agencies within the Executive Branch to run their draft regulations by the White House's Office of Management and Budget in the White House before promulgating them, a sea change in the structure of the federal bureaucracy that marked the beginning of ever greater amounts of presidential control over it. The Clinton Administration's cognate Executive Order No. 12,866 underscored the need for OMB to review. particularly significant regulatory action on a cost-benefit plan and adopted an annual regulatory planning process.

327. As the New York Times has reported, "[B]y all outward appearances, Mr. Bush has been reduced this week to almost a bit player in his own government, as Washington has reoriented itself away from the White House and toward Treasury Secretary Henry $M$. Paulson Jr. and the Federal Reserve chairman, Ben S. Bernanke." Sheryl Gay Stolberg, Bush Emerges After Days of Financial Crisis, N.Y. Times, Sept. 19, 2008, at A1. Bernanke heads the Federal Reserve, which is an independent agency outside of the Executive Branch's control in that he and his fellow Federal Reserve Board members may not be fired 
A Rejection of Federalism. On the other hand, those public law scholars inclined to focus on the importance of states in our federal system must consider the all-but-nonexistent role that states have played in the crisis response. ${ }^{328}$ If anything, the bailout phenomenon of states lining up for a piece of the federal bailout, and the ensuing prospect of federal supervision over the money, is a rebuke to the often too hopeful fans of federalism. ${ }^{329}$ The states have had almost nothing useful to add to the federal government's response to the crisis. Some have suggested that their passivity is a sign of wise laissez-faire, suggesting that there are only federal supremacists in foxholes. During the crisis, those state officials with the capacity to act-the Delaware Court of Chancery, which briefly entertained the Bear Stearns shareholder litigation, for example, or the prosecutors in the New York State Attorney General's Office-have either gotten out of the way of or cooperated with federal officials. ${ }^{330}$

An Embrace of Alternative Governance. While courts and states are the missing players in this administrative law paradigm, the new process of regulation by deal exemplifies some trends that are increasingly apparent in modern administration. The deals marked a turn by the government toward an administrative approach with much in common with what some have called New Governance. ${ }^{331}$ That sort of governance tends to involve public-private partnerships, a more networked approach to regulation, and regulatory action positioned outside of the range of judicial review. ${ }^{332}$

The governance model adopted during the early stages of the financial crisis featured all of these hallmarks and, because it did so, helps to

except for cause, are confirmed by the Senate, and have budget powers apart from those of the president. See Paul R. Verkuil, The Purposes and Limits of Independent Agencies, 1988 DUKE L.J. 257, 278 ("The Federal Reserve Board (FRB) leaps to mind. It is one of the largest, truly independent agencies (right down to an independent Chair), but it is a policymaker of the highest order.").

328. See, e.g., Stuart Minor Benjamin \& Ernest A. Young, Tennis with the Net Down: Administrative Federalism Without Congress, 57 DUKE L.J. 2111, 2150-51 (2008) (describing the way the courts could interpret the Constitution to ensure a role for state autonomy).

329. See Rob Hotakainen, States Want Their Own Federal Financial Bailout, MCCLATCHY, Nov. 15, 2008 ("Led by California with a $\$ 28$ billion hole in its budget, 41 states are in financial trouble, and many of their leaders are looking to Congress to bail them out."), available at http://www.azcentral.com/news/articles/2008/11/14/20081114economystates 1114-ON.html.

330. See supra notes 74-78 and accompanying text. The New York State Attorney General's Office instead focused on more-high-profile issues such as executive compensation and perks provided at AIG. See Hugh Son, New York's Cuomo Queries AIG on Bonuses and Raises, BLOOMBERG.COM, Nov. 18, 2008, $\mathrm{http} / /$ www.bloomberg.com/apps/news?pid=20601 103\&sid=arDpTEBIMPe8\&refer=us.

331. For a discussion of New Governance, see, for example, Orly Lobel, The Renew Deal: The Fall of Regulation and the Rise of Governance in Contemporary Legal Thought, 89 MinN. L. REv. 342, 344 (2004).

332. See id. at 342,466 . 
illustrate the limits of the traditional paradigms of administrative procedure. That traditional paradigm is, it appears, fine for ordinary administration but less clearly appropriate for emergency governance. ${ }^{333}$ Nor is the traditional paradigm being used particularly vigorously, even in traditional areas of administrative law. As the government pursues these sorts of public-private models in other areas, and adopts business-style approaches like best practices and benchmarking to do the sorts of things that rules used to be used to do, that traditional model is looking more and more pinched by government practice, both typical and, as in the case of the financial crisis, atypical. ${ }^{334}$

At any rate, regulation by deal is yet another example of administration through an alternative to the traditional administrative law, and while its flexibility and creativity have their benefits, the alternatives look different from traditional administrative law in both good and bad ways. New Governance is not without costs, as illustrated by the response to the financial crisis. Government by deal has not been open government (the government did not divulge the deals it was doing until those deals were concluded), and it rejects some of the usual values of administrative law, such as predecision notice to affected parties and the public and commentventilated policymaking. ${ }^{335}$ It also made very substantial and expensive government decisions very quickly, in contrast to the measured process contemplated by the APA.

Much more can be said about this form of administration than simply that it is different. In fact, if taken seriously, it comes at governance and regulation from a different conceptual starting point. For the dealmaking heralded the privatization of government functions, which, during this period, were "run like a business" rather than as a regulator. By doing deals, the government embraced the model that organizational analysts ranging from Tom Peters to Al Gore have urged on it. ${ }^{336}$ Supervision by acquisition, and then, presumably, a form of activist investor participation in governance, is a very different sort of oversight than the traditional paradigm of supervision separate and apart from the privately run financial industry.

A Possible Corporatist Turn. Finally, on the regulatory side, we mildly note that the government's response to the financial crisis took it toward a

333. See Eric A. Posner \& Adrian Vermeule, Crisis Governance in the Administrative State: $9 / 11$ and the Financial Meltdown of 2008, at 46 (Univ. of Chi. Law Sch. Pub. Law and Legal Theory, Working Paper No. 244, 2008), available at http://papers.ssrn.com/sol3/papers.cfm?abstract_id=1301164.

334. For further examination of these trends, see Zaring, supra note 325.

335. See 5 U.S.C. $\$ \S 553-556$ (2006) (presenting certain statutory requirements for agency process).

336. See supra note 11 and accompanying text. 
more corporatist approach to governance. Corporatism puts all the relevant parties-shareholders, stakeholders, and regulators-in the same room, with stakes in the outcome of what essentially becomes negotiated regulation. ${ }^{337}$ It is a more European model of governance and has long been eschewed in the United States in favor of a more command-andcontrol model of regulation.

But corporatism is a useful shorthand for understanding the governance implications of the response to the financial crisis. By investing in financial institutions, the government has injected itself into commerce in a novel way-a way that is very different from the sort of approach traditionally adopted in American administrative law. This new approach is fundamentally different not from administrative procedure as it is practiced in the United States, but administration as it has usually been conceived.

Law's Role in Emergency. The last great emergency faced by the country was the $9 / 11$ crisis, and the government's response to the collapse in finance has some similarities with the aftermath of the terrorist attacks. In both cases, the Executive Branch announced a number of controversial new programs, even warfare, and Congress, for the most part, got out of the way, providing broad authorizations for executive response replete with discretion and limitations on oversight. Some, including Eric Posner and Adrian Vermeule, would put this down to the Schmittian inevitability of executive decisiveness overruling legislative indecision in emergencies. ${ }^{338}$ In this account, law tends to go by the wayside in emergencies.

Still, we are not persuaded that the government's response marks the irrelevance of legal constraint in a crisis. As we have explained, the government acted primarily through the Federal Reserve-which, as an independent agency, is certainly not part of the Executive Branch-because that institution had the legal authority to press its claims while, for

337. Corporatism has a number of definitions. To put it slightly sociologically, it represents a Mitteleuropean structure of government that collects stakeholders in a single decisionmaking structure in which each of them has a voice and all of them together have a monopoly. See, e.g., Philippe C. Schmitter, Still the Century of Corporatism?, in TRENDS TOWARD CORPORATIST INTERMEDIATION 7, 13 (Philippe C. Schmitter \& Gerhard Lehmbruch eds., 1979) (defining corporatism as "a system of interest representation in which the constituent units are organized into ... categories, recognized or licensed (if not created) by the state and granted a deliberate representational monopoly ... in exchange for observing certain controls on their selection of leaders and articulation of demands and support"). For a more general review of corporatism, see William W. Bratton \& Michael L. Wachter, Shareholder Primacy's Corporatist Origins: Adolf Berle and the Modern Corporation, $34 \mathrm{~J}$. CORP. L. 99 (2008).

338. See Posner \& Vermeule, supra note 333, at 3; see also Adrian Vermeule, Our Schmittian Administrative Law, 122 HARV. L. REV. 1095, 1096 (2009) ("Legal black holes and grey holes are best understood by drawing upon the thought of Carl Schmitt, in particular his account of the relationship between legality and emergencies."). 
example, Treasury acting alone did not. And while the bailout statute certainly bequeathed an awesome amount of power on the government, the details of the grant changed substantially between the initial three-page proposal by the government and the 412-page bill that Congress passedso much so that the equity injections the government settled on in response to the crisis would not have been possible unless Congress had legislated the way it did.

Un-Path-Depending Deals. The implementation of the crisis also evinces a context in which the path dependence of dealmaking can be overcome. Lawyers, of course, structure new deals on the precedent of old ones. ${ }^{339}$ This is partly a rational inclination to resist reinventing the wheel, but partly the kind of path dependence that brings to mind the innovationsuppressing sort of network effects. ${ }^{340}$ In the time-sensitive environments of the bailout, one might expect to see an amplification of boilerplate and repetition. And we did see some apparent errors in the hurried negotiation of the Bear Stearns deal. But the government's deals looked quite different from traditional privately negotiated deals. The government's deals were structured to take advantage of the law it had and seemed, at least until the congressionally legislated bailout, to be made in full awareness of the powerful negotiating position enjoyed by the government. Despite the mistakes and unintended consequences, the resulting innovative deals suggest that the new player, albeit staffed by veteran dealmakers, was able to innovate and close aggressively, showing the potential of lawyers and dealmakers when they are partially unconstricted by normal agency and signaling costs to create more-efficient structures. In the process the government has created its own new precedent to follow for future government bailouts.

Venture Capital Versus Private Equity Deal Models. There are other ways to think about deals, even outside of the context of what lawyers and negotiators can do to negotiate and improve them. For example, as the government has gradually become accustomed to taking stock in distressed financial institutions, it has turned away from the role of dealmaking middleman, a traditional role for investment bankers and the one it took in Bear Stearns, and toward the actual role of investment and investor.

Investor dealmaking has often been examined in two ways: through the venture capital model and through the private equity model. ${ }^{341}$ We think it

339. See Davidoff, supra note 12; see also Gilson, supra note 13, at 257-58.

340. For a technical discussion, see David T. Robinson \& Toby E. Stuart, Network Effects in the Governance of Strategic Alliances, 23 J.L. ECON. \& ORG. 242 (2007).

341. For background on private equity and venture capital, and the differences, see JACK S. LeVIn ET Al., StRucturing VENTURe CAPITAL, PRIVATE EQUITY, AND ENTREPRENEURIal TRANSACTIONS (2006); ANDREW METRICK, Venture Capital and the FinanCE of 
is useful to understand that the government has been acting more as a venture capitalist than as a private equity investor, even though private equity might have been thought to be the more prominent dealmaking paradigm. Moreover, we mildly posit that the government's response to the financial crisis underscores the differences between the two paradigms through which nonstrategic deals can be analyzed; in short, we suspect that the financial crisis can tell us something useful and illustrative about dealmaking models.

The role of the investor-dealmaker, of course, varies with the type of transaction completed. As David Weisbach has explained, "Venture capital funds invest in start-up companies with the hope of a public offering sometime in the future. Leveraged buyout funds," the private equity approach, in our typology, "purchase existing companies and take them private, with the hope of restructuring the business and selling it at a profit., 342

Private equity dealmakers, then, tend to take control of the firm with an eye to restructuring it and selling it off later for a profit. The government's financial crisis approach has looked a little like this-but not a lot like it. The government took warrants in some of its transactions before the passage of EESA and in most of them after it. Stock warrants are preferred private equity instruments-they have a future exercise date and are accordingly often how the private equity investors structure their payout and exit. But otherwise the government during this period stayed away from taking control of the financial institutions it bailed out, which private equity investors, unless they are supporting a management buyout, tend not to do. Private equity investors rather prefer maximum control in order to have flexibility to restructure the corporate enterprise for a future sale.

Instead, the government's deals have looked a bit more like a venture capital model. "Venture capital is a substantial equity investment in a nonpublic enterprise that does not involve active control of the firm," as George Dent has explained. ${ }^{343}$ Instead venture capitalists leave the management of the firm in place-think technology companies with a new idea and management with a vision-but offer money and expertise to the venture. They also tend to structure their funding through a series of rounds that puts the owners and operators of the venture on a schedule that

InNovation (2007); James M. Schell, Private Equtty Funds: Business Structure and OPERATIONS (2009).

342. David A. Weisbach, The Taxation of Carried Interests in Private Equity, 94 VA. L. REV. 715, 721 (2008).

343. George W. Dent, Jr., Venture Capital and the Future of Corporate Finance, 70 WASH. U. L.Q. 1029, 1031 (1992). For more on the model, see Ronald J. Gilson, Engineering a Venture Capital Market: Lessons from the American Experience, 55 STAN. L. REV. 1067 (2003). 
they must meet to obtain more funding. ${ }^{344}$ This timeline tends to leave the private equity investors with a great deal of control over the company, even as ownership is left in the hands of the original owners and operators.

The venture capital model is the one that the government has chosen to make its dealmaking paradigm, while the private equity model-which would look more like outright nationalization-is the one it eschewed, at least as the crisis evolved. It has provided money and its reputation (in lieu of the ordinary venture capital infusion of expertise) to financial institutions in exchange for an ownership stake in many of them. It has even set a schedule for repayment, as venture capitalists tend to do, with penalties in the form of high interest for repayments that are delayed. But it has left the management of financial institutions in place to continue to run their enterprises, as is common for venture capitalists. ${ }^{345}$

The result is not a particularly happy marriage of venture capital dealmaking principles and a reality in which the management of the bailedout institutions has been left in place despite having few similarities with the technology start-ups most associated with venture capital. Many of the financial institutions that have suffered most during the crisis, to the point of needing government assistance, have management that has not distinguished itself regarding its oversight of their company's balance sheet and careful parsing of risk. These management teams do not all have the potential of the owners and operators of promising technology start-ups, yet the government has stood by them, other than to intermittently urge them to loan out the money the government has disbursed to them.

Moreover, the tasks for financial institutions bailed out by the government-restructuring, deleveraging, shrinking, and, eventually, a spin-off-are the sort of tasks that one would ordinarily think a private equity deal would be best suited to do, rather than one modeled on a venture capital paradigm. The result has placed the government in a difficult situation. As an outside investor, one who has in most cases left management in place, its ability to steer policy in the financial institutions in which it has taken a stake is limited. ${ }^{346}$ This model was no doubt adopted purposefully in order to hamper future, political government

344. See Gilson, supra note 343 , at 1073.

345. It replaced the management teams at Fannie Mae, Freddie Mac, and AIG.

346. See D. Gordon Smith, Corporate Governance and Managerial Incompetence: Lessons from Kmart, 74 N.C. L. REV. 1037, 1046-57 (1996) (describing some of the limitations of activist investing). But see Alon Brav et al., Hedge Fund Activism, Corporate Governance, and Firm Performance 2-3 (European Corporate Governance Inst. (ECGI), Finance Working Paper No. 139/2006; Vanderbilt Univ., Law \& Econ. Research Paper No. 07-28, 2007), available at http://papers.ssrn.com/sol3/papers.cfm?abstract_id=948907 (finding that activist shareholders, particularly hedge funds, tended to add value to publicly traded companies). 
interventions, but it has had the perhaps more deleterious effect of depriving the government of an important ability to effect seemingly needed corporate change.

There is no question that executive and independent agencies have stretched their legal authority during the bailout crisis. In some cases they have done so beyond recognition; the Federal Reserve's broad interpretation of the set of candidates to whom it could open its discount window during the crisis has made a mockery of the view that the law should not be interpreted to disturb the settled expectations of those affected by it. ${ }^{347}$ Part of this was driven by the statutory constraints on the government, failings which may point to possible legislative reform to allow the government to act in future financial crises. But in other contexts, agencies like the Federal Reserve were turned to precisely because they had the legal authority to act. Deals were selected because they also loosened the government from its regulatory constraints. Rather than concluding that legal constraints have no purchase in emergencies, we think that perhaps the conclusion should be that settled expectations are quickly unsettled in crises, creating opportunities for novel legal interpretations, rather than that crises mean that the rule book no longer applies. And we think that in future emergencies the government may manage its authority limitations through regulation by other means when it is unable to turn to a legislative response due to political, timing, or other constraints. This may be regulation by deal.

347. See, e.g., Daniel B. Rodriguez, Of Gift Horses and Great Expectations: Remands Without Vacatur in Administrative Law, 36 ARIZ. ST. L.J. 599, 622 (2004) (recommending that we "give some deference to these settled expectations in designing remedies in administrative law"). 
